\title{
Memoirs of the Four-Foot Colonel
}

Gen. Smith Dun

First Commander-In-Chief of Independent Burma's Armed Forces

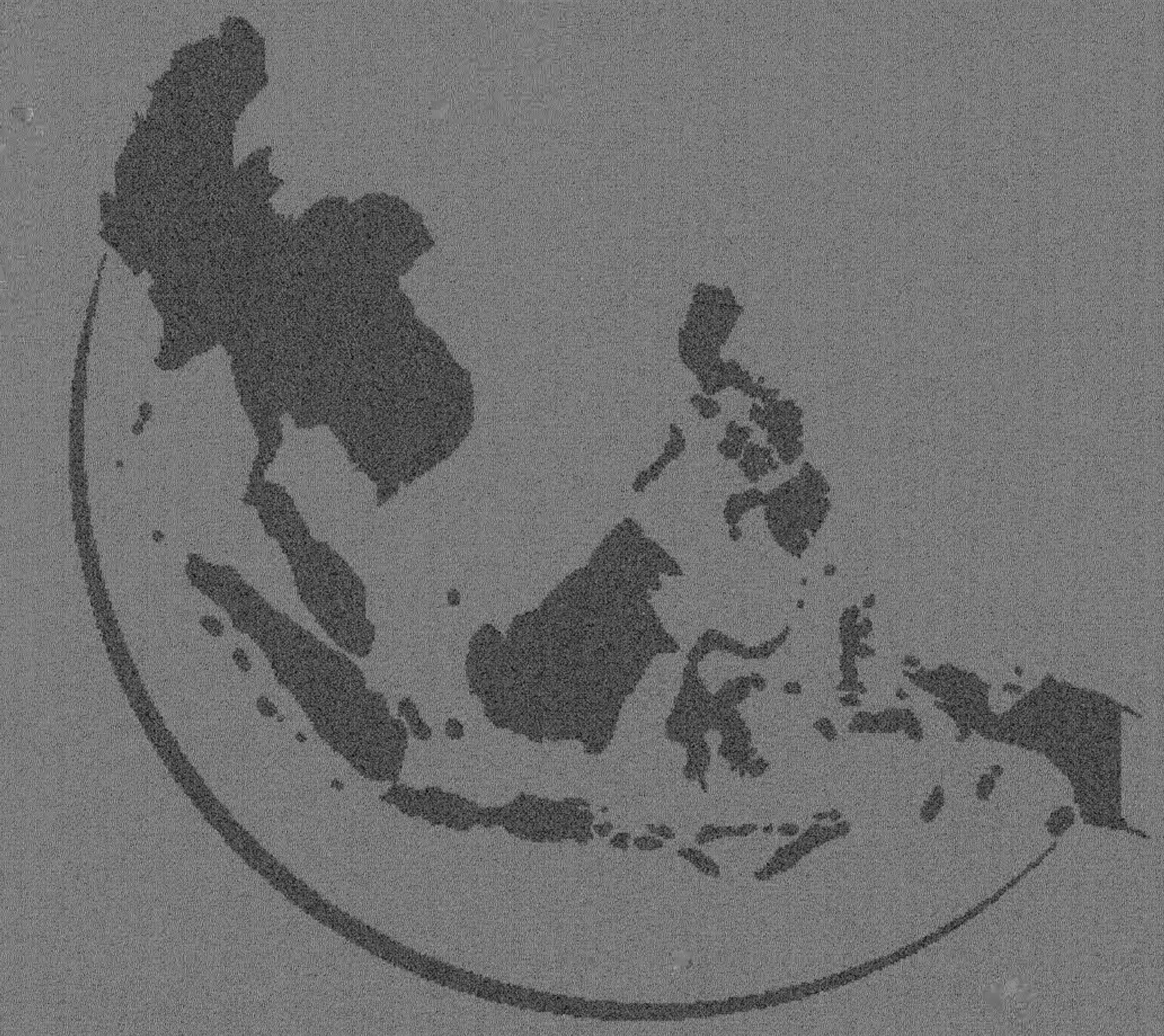

Southeast Asia Program Publications Data Paper No. 113 

MEMOIRS OF

THE FOUR-FOOT COLONEL 


\section{THE CORNELL UNIVERSITY SOUTHEAST ASIA PROGRAM}

The Southeast Asia Program was organized at Cornell University in the Department of Far Eastern Studies in 1950. It is a teaching and research program of interdisciplinary studies in the humanities, social sciences, and some natural sciences. It deals with Southeast Asia as a region, and with the individual countries of the area: Brunei, Burma, Indonesia, Kampuchea, Laos, Malaysia, the Philippines, Singapore, Thailand, and Vietnam.

The activities of the Program are carried on both at Cornell and in Southeast Asia. They include an undergraduate and graduate curriculum at Cornell which provides instruction by specialists in Southeast Asian cultural history and present-day affairs and offers intensive training in each of the major languages of the area. The Program sponsors group research projects on Thailand, on Indonesia, on the Philippines, and on linguistic studies of the languages of the area. At the same time, individual staff and students of the Program have done field research in every Southeast Asian country .

A list of publications relating to Southeast A sia which may be obtained on prepaid order directly from the Program is given at the end of this volume. Information on Program staff, fellowships, requirements for degrees, and current course offerings is obtainable from the Director, Southeast Asia Program, 120 Uris Hall, Cornell University, Ithaca, New York 14853. 
MEMOIRS OF

THE FOUR-FOOT COLONEL

\author{
by \\ Gen. Smith Dun \\ First Commander-in-Chief \\ of Independent Burma's Armed Forces
}

Data Paper: Number 113

Southeast Asia Program

Department of Asian Studies

Cornell University, Ithaca, New York May 1980 


\section{Editorial Board \\ Benedict Anderson \\ George Kahin \\ Stanley O'Connor \\ Keith Taylor \\ Oliver Wolters}

Cornell Southeast Asia Program Publications

640 Stewart Avenue, Ithaca, NY 14850-3857

Data Paper Series No. 113

(C) 1980, Cornell Southeast Asia Program.

Published in 1980. Second Printing 2004.

All rights reserved. Except for brief quotations in a review, no part of this book may be reproduced or utilized in any form or by any means, electronic or mechanical, including photocopying and recording, or by any information storage or retrieval system, without permission in writing from the Cornell Southeast Asia Program.

Printed in the United States of America

ISBN $0-87727-113-5$ 


\section{CONTENTS}

Page

PREFACE

vii

MAP. BURMA : CIRCA $1945 \ldots \ldots \ldots \ldots \ldots \ldots \ldots \ldots \ldots \ldots \ldots \ldots \ldots \ldots$ viii

INTRODUCTION $\ldots \ldots \ldots \ldots \ldots \ldots \ldots \ldots \ldots \ldots \ldots \ldots \ldots \ldots \ldots$ ix

FOREWORD BY GENERAL D. T. COWAN .................. xi

AUTHOR'S INTRODUCTION $\ldots \ldots \ldots \ldots \ldots \ldots \ldots \ldots \ldots \ldots \ldots \ldots \ldots \ldots \ldots \ldots \ldots \ldots \ldots$

Chapter

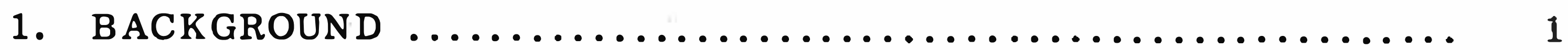

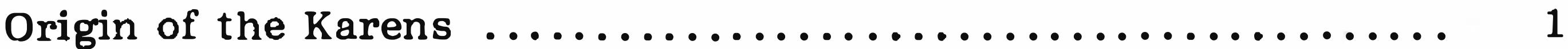

Characteristics of the Karens ....................... 4

Book Tradition ................................... 5

2. EARLY LIFE OF THE FOUR-FOOT COLONEL .............. 8

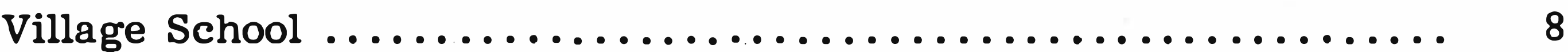

Government High School ......................... 9

3. A VISIT TO ENGLAND: SERVICE IN THE RANKS: THE INDIAN

MILITARY ACADEMY $\ldots \ldots \ldots \ldots \ldots \ldots \ldots \ldots \ldots \ldots \ldots \ldots \ldots \ldots \ldots \ldots$

Indian Military Academy $\ldots \ldots \ldots \ldots \ldots \ldots \ldots \ldots \ldots \ldots \ldots \ldots \ldots,{ }_{12}$

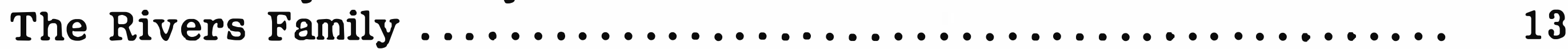

Indian Military Academy $\ldots \ldots \ldots \ldots \ldots \ldots \ldots \ldots \ldots \ldots \ldots \ldots$

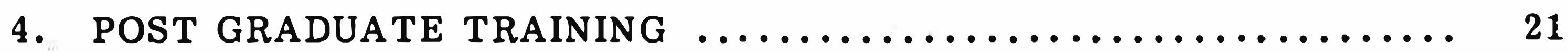

A Year with the British Unit ......................... 21

2nd Battalion, 1st Punjab Regiment ................... 21

B urma Military Police ............................ 23

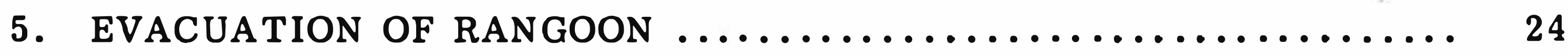

Early Desertion of Karens in B.M.P.................. 25

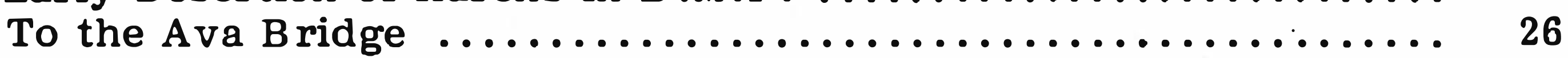

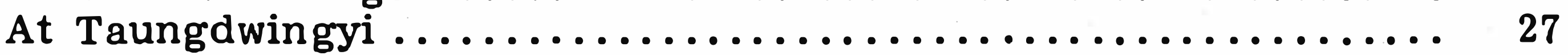

6. WITHDRAWAL FROM SAGAING, KALEWA, TO IMPHAL ......... 29

7. STAFF COLLEGE QUETTA, REJOIN 17TH DIV., CHIEF LIAISON OFFICER IN BURMA INTELLIGENCE CORPS ............... 35

8. REORGANIZATION, TRAINING AT MHOW, CENTRAL INDIA ..... 47

9. POSTED TO 7 TH DIV., REOCCUPATION OF BURMA ........... 48

10. CAREER WITH POSTWAR BURMA ARMY TO SELF-IMPOSED

EXILE, KACHIN STATE $\ldots \ldots \ldots \ldots \ldots \ldots \ldots \ldots \ldots \ldots \ldots \ldots \ldots \ldots$

Self-Imposed Exile ............................ 54 
Chapter $\quad$ Page

11. THE BURMAN-KAREN TROUBLES $\ldots \ldots \ldots \ldots \ldots \ldots \ldots \ldots \ldots \ldots \ldots \ldots$

The B urmans' Point of View ........................ 60

The Karens' Point of View .......................... 63

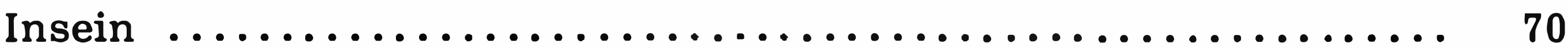

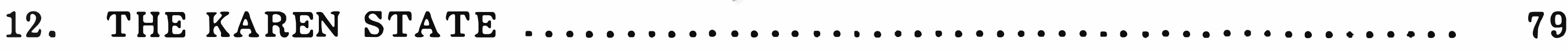

Notes by the Author $\ldots \ldots \ldots \ldots \ldots \ldots \ldots \ldots \ldots \ldots \ldots \ldots \ldots \ldots . \ldots \ldots$

13. THE KAREN SOLDIER $\ldots \ldots \ldots \ldots \ldots \ldots \ldots \ldots \ldots \ldots \ldots \ldots \ldots \ldots \ldots$

World War I ................................... 104

Karen Levies .................................. 107

The Unknown Karen Soldiers ....................... 112

Martial or Non-Martial Race ........................ 114

14. DUN THE SHIKARI .............................. 117

Last Shoot with Colonel Coleridge ..................... 120

15. GOD'S CARE AND GUIDING HANDS $\ldots \ldots \ldots \ldots \ldots \ldots \ldots \ldots \ldots \ldots \ldots$

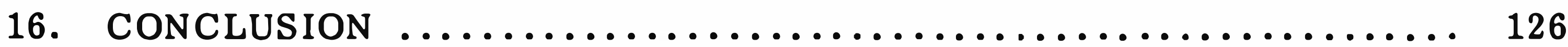




\section{PREFACE}

Memoirs, whether of those in high place or low, are prime sources for the detail and color which flesh out the spare frame of history, bringing to it that sense of human vitality so necessary for real understanding. Smith Dun was one of those who rose to high place indeed--from Karen farm boy to Commander-in-Chief of the army of Burma in little more than the first half of his life. His memoirs, filled with color and humor, give us an account of the struggle for Burmese independence which is unique. As a Karen himself he provides us with special understanding of both the Karen peoples and that difficult period of Karen rebellion following independence. His story is without guile or bias. With keen appreciation of his Karen-ness he yet remained a loyal soldier of Burma throughout his life.

Editing of these memoirs has been limited to questions of clarity in order to preserve as fully as possible the vivid flavor of Smith Dun's English style. The author included many lengthy quotations and, although some of them are not otherwise inaccessible, they acquire new significance in the context of this story; these have been identified and cited in so far as possible.

The Southeast Asia Program is pleased and honored to have the opportunity to make available these memoirs of a most important period of Burmese history written by one of its chief protagonists--the Four-Foot Colonel.

Robert B. Jones 


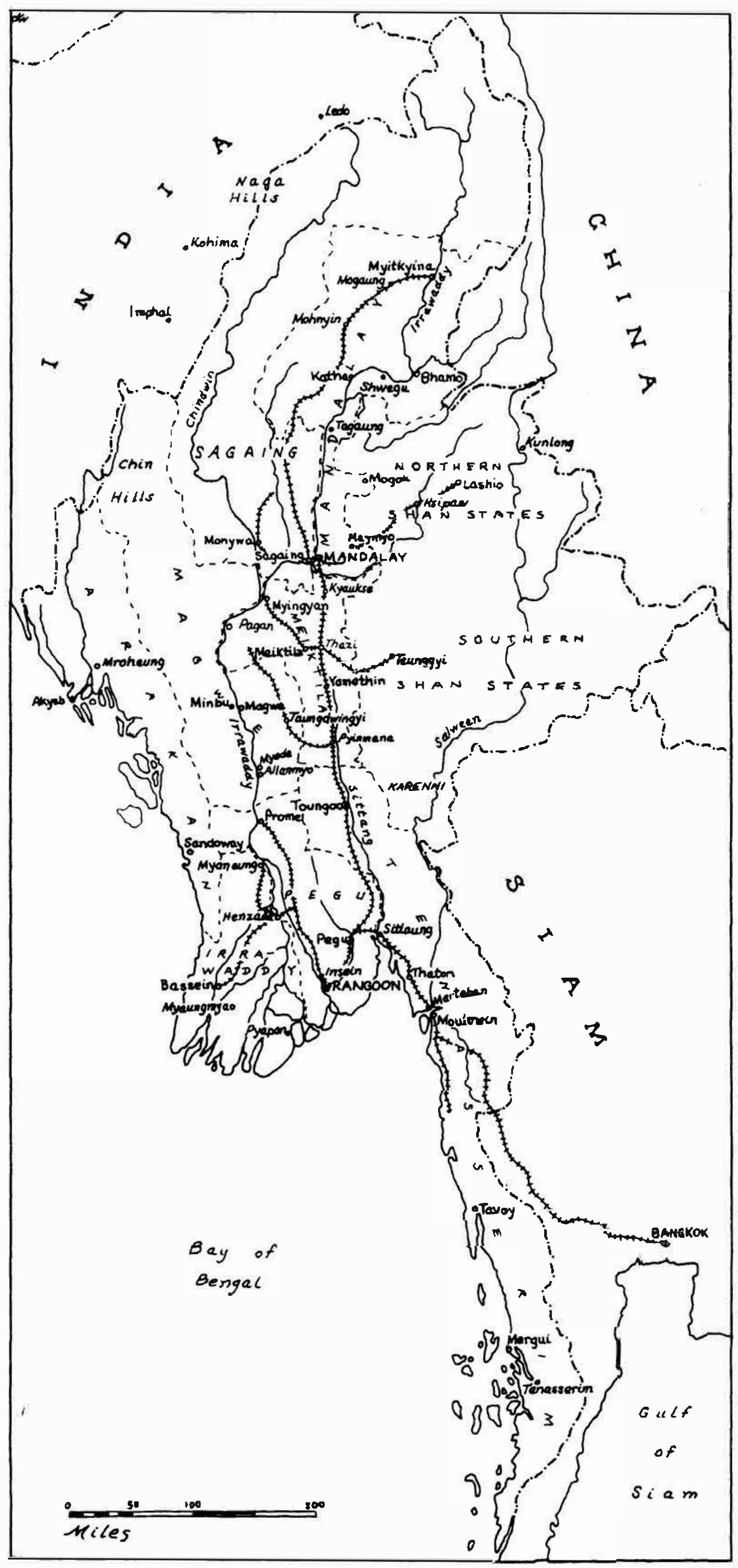

BURMA : CIRCA 1945 


\section{IN TRODUCTION}

General Smith Dun died in 1979 in Kalaw, Shan State, Burma. Born on November 11,1906 in the Irrawaddy Delta, he was virtually a forgotten figure in contemporary $B$ urmese history, if not in the minds of many of his older countrymen.

The general lived in quiet retirement for thirty years in Maymyo, Myitkyina, and Kalaw. His tranquil life and intentional obscurity from the public masked strongly held views on the state of Burma and its directions. His reluctance to resume a public posture was in the best traditions of the military education he received and the rank he held. He was a good and loyal soldier of the Union of Burma.

General Smith Dun's critical role in Burmese history was a product neither of his military exploits nor of the important position he held as Commander-in-Chief of the Burma army. It was, rather ironically, a result of his initial appointment to that position and his departure from it.

To some he may appear to be a footnote to contemporary Burmese history, but he was more than that. In the standard accounts of the transition from colonialism to Burmese independence and of the early and traumatic years of the Republic, he is usually mentioned only in passing. However, his appointment was an essential element in the formation of the Union of Burma.

In 1947, the Burman leadership under the direction of Aung San was negotiating with both the British and the minority groups on the nature and scope of the new state. There was considerable debate on the extent of the proposed state and on the inclusion of the minority groups that, under B ritish rule, had been governed separately. These negotiations reached a climax at the critical meeting that began on February 7, 1947 at the town of Panglong in the Shan State, where the minority groups were brought together by Aung San to discuss the state's composition. At the meeting, which the Karens also attended as observers, the Shan and Kayah States were given the right of secession after ten years, should their inclusion in the Union of Burma not prove to their satisfaction. A Kachin State was also planned but, since it would contain substantial areas that were Burman in population, it was not allowed to leave the Union.

The Karens, of whom General Smith Dun was one, were a special problem. They were more articulate and more Anglicized than the other groups because of the larger proportion of Christians among them. Their centers of population in the mountains of eastern Burma and in the Irrawaddy Delta were interspersed with those of B urmans and other groups. Because of their perceived special relationship with the British and their cooperation with them against the Japanese in the Second World War, the Karens had hoped for independence--an independence that the Burmans were not prepared to grant.

In this context General Smith Dun played an important role. To assuage the Karens' fears and to demonstrate that the new Burma, soon to be independent once again, would indeed be a union in which various ethnic groups participated in the process of national formation and growth, it was agreed that General Smith Dun would be given command of the Burma army. Before World War II the Burmese armed forces had a large percentage of Karens recruited by the British, and after independence General Smith Dun became the personification of Burman good faith towards the Karens. Although he had a strong sense of Karen consciousness, he was a loyal soldier of the Union.

On independence, General Smith Dun was appointed Commander-in-Chief of the army and of the police forces, with $\mathrm{Ne}$ Win as his deputy. His tenure as commander 
was short-lived, for, with the very structure of government endangered by the Karen rebellion and Karen troops threatening Rangoon, Smith Dun was removed from his command on February 1, 1949. He was placed on indefinite leave, and never returned. ${ }^{3} \mathrm{U} \mathrm{Nu}$, in his autobiography, wrote that Smith Dun "found his position untenable when the KNU (Karen National Union) revolted. He then took leave preparatory to retirement. The government did not force him to go on leave. On the contrary, the defense minister, on the instructions of the premier, tried to persuade him to return to active duty." ${ }^{2}$ General Smith Dun tells a somewhat different story. He resigned when Burmese troops burned the Karen quarter of the Rangoon suburb of Thamaing and $U$ Nu preferred to deal with Smith Dun's deputy, Ne Win. The general's loyalty to the Union remained strong, and it was to his credit that he was able to keep the Karen military units under control during that difficult period. ${ }^{3}$

Nothing became the general more than the manner in which he left the high position he had held. He remained faithful to the government and was exemplary in his dealings with the civil authorities during that turbulent period. Had he joined the insurgent Karen forces, the history of Burma might well have been different.

About 1960 I was privileged to pay a call on General Smith Dun in his home in Maymyo, when we had tea together, and he told me something of his life. At that time he gave me a copy of the manuscript, The Four-Foot Colonel, the memoir of his life up to that time. He wanted me to read the manuscript, but he also clearly wanted to ensure that it would some day reach a wider audience.

I kept the memoirs, secure among boxes of Burmese materials, throughout my peregrinations in Asia. With Smith Dun's death in 1979, it seemed appropriate to seek their publication. General Smith Dun may have prepared additional chapters of his autobiography after I met him, but if they exist, they are not available to me. I hope, however, that, if they are discovered, they might also some day be published.

The importance of this memoir lies in its first-hand account of the rise of a talented and determined man through one of the few channels of social mobility existing during the colonial period and the early years of independence. It offers rare insight into the views and motivation of a man who was loyal to his country and to the traditions of his training. This autobiography stresses the two aspects of his life about which he felt most keenly: his military life and his Karen ethnicity. The role of the Burmese military and the ethnic divisions within the country remain two of the major factors that will shape Burma's future.

I would like to thank Cornell University for publishing this work and especially Professor David Wyatt for his interest in it and in contributing to our understanding of Burma during this important period.

David I. Steinberg

Bethesda, Maryland

March, 1980

1. Hugh Tinker, The Union of Burma (Oxford: Oxford University Press, 1957), p. 40 .

2. U Nu, Saturday's Son (New Haven: Yale University Press, 1975), p. 173n.

3. John Cady, The United States and Burma (Cambridge: Harvard University Press, 1976), pp. 199-200. 
FOREWORD BY GENERAL D. T. COWAN

\author{
Lower Coombe \\ Bovey Tracey \\ South Devon, England
}

2. 11.58

The author has honoured me by asking me to write a Foreword to his Memoirs. I do so very gladly.

S. Dun and I first met when he arrived in the first batch of cadets to the Indian Military Academy, Dehra Dun.

In a very short space of time he made his mark there, and became the first under officer in my Company--"B" Company which in no small measure owing to his leadership and personality became the Champion Company.

S. Dun earned the respect, admiration and affection of both Instructors and Cadets and was presented with the Sword of Honour on passing out from the Indian Military Academy.

In the 1939-1945 war he and I met again when he served under me in the 17th Indian Division ( $T$ he Black Cats). In war he again proved himself a leader and by his work on active service obtained a nomination to the Staff College.

When Burma obtained self government he was the obvious choice as Commanderin-Chief, and was duly selected. His record was, therefore, outstanding, rising as he did from the ranks by merit-promotion, to become a Commander-in-Chief.

I have not had the good fortune to read the Memoirs but, knowing the author, I am confident that they will be full of interest and by no means devoid of humour.

His comrades of the 17 th Indian Division will always remember, with great respect and affection, their friend "The Four-Foot Colonel.s

Signed: D. T. Cowan

G.O.C. 17th Indian Division

(The Black Cats) 


\section{AUTHOR'S INTRODUCTION}

The story of a four-foot Colonel is about no other person than General Smith Dun, with important and relevant incidents that occurred in the course of his life. He was known to all his intimate friends as Smithy, especially to his British and American friends.

His interest in Army life was aroused at a tender age by Karen soldiers returning on leave and recruiting duties, who came to his village. He would listen with great interest for hours to those soldiers who would be relating their experiences of travel and adventures of the First World War. Among those soldiers there were many from his own village, including his elder brother, who came back as a Naik or Corporal at the end of the First World War. His enthusiasm was heightened by hearing more stories from his brother. From that time his one and only dream for his future was to become a soldier and to see and experience all that he had heard. In his dream for the future, one thing which was outstandingly embedded in his mind was to rise to the top rank, and to go through a hellish war, at the end of which, to come out unscathed and take part in the victory parade in London as was done after the First World War.

All his dreams came true, in fact more than he dreamed. At that time, the highest rank to which a native soldier could rise from the ranks was Subadar Major (A Viceroy Commission).

It was Field-Marshal Sir William Slim who gave him the name of "Four-Foot Colonel." Sir William came to know him from his cadet days. During one of the General's visits at the Indian Military Academy at Dehra Dun, there was a physical efficiency test for all the cadets. In the high jump, although Dun was the shortest, he jumped the highest and incidentally above his height. During the victory parade for the Second World War in 1946, the two were chatting together in Kensington Gardens one evening; Sir William casually remarked to one of the reporters near by, introducing him by saying, "This is Colonel Dun (Doon) who is only four feet tall, but used to jump one inch above his height," and also added, "I wonder if he can do it now though."

The same evening the photograph of the Four-Foot Colonel and all his achievements came out in one of the papers (Star or Evening Star I am not quite sure now). It was quite an advertisement for him. 


\section{CHAPTER I}

\section{BACKGROUND}

The following is an honest attempt to trace the origin of the Karens in the light of their tradition and records left by the early missionaries and B ritish Government officials who came in contact with them in the last century.

\section{Origin of the Karens}

There are White Karens, Red Karens, Black Karens, Striped, etc.s so designated from the colour of their dress. The Shan name for Karen is Yang. In Burmese pronunciation we hear of Yens, Yeins, Yenbows, Yen-Seik. The Red Karens called themselves Kayah and some of the Bghai Karens called themselves Kayay, which might have been the origin of the Burmese word, though it had been derived from "Ayin" (prior time) and a primitive particle, thus signifying aboriginal. But it is quite certain that the Karens are not the aboriginal inhabitants of Burma, says Dr. Mason. He has also said:

In my early travels, the Karens pointed out to me the precise spot where they took refuge in the days of Alompra; and where they had come down and avenged themselves on their enemies, but when I asked them who built this city, as we stood together on the forest-clad battlement of a dilapidated fortification, they replied these cities of our jungles were in ruins when we came here. This country is not our own, we came from the North, where we were independent of the Burmese, the Siamese, and the Talaings who now rule over us.

There we had a city and country of our own near Ava called Taungoo. All the Karens of Siam, Burma and Pegu came originally from that region. When I asked for the time of dispersion they were silent. The fact was clearly before them, but the retrospect was too obscure to determine the distance. Yet they saw far beyond Taungoo. On the edge of the misty horizon was the river of the running sand, which their ancestors had crossed before coming. That was a fearful trackless region where the sand rolled before the wind like the waves of the sea. They were led through it by a chieftain who had more than human powers to guide them. Saw Quala, when he first related the tradition, remarked that the whole story seemed to him like Moses guiding the children of Israel across the Red Sea and through the desert.

To what river or water of running sand referred to was quite an enigma to me for several years, till I met with the journal of the Chinese Buddhist Pilgrim FA HIAN who came from China to India in the early part of the 5th Century of the Christian era. He thus designated the great desert between China and Tibet. The Governor of the town of sands, he says, furnished his party with necessary means of crossing the river of sands. He continued: "And such scorching winds that who so encountered them dies and none escape. Neither birds are seen in the air, nor quadrupeds on the ground. 
On every side as far as the eyes can reach, if you seek for the proper place to cross there is no other mark to distinguish it than the skeletons of those who have perished there; those alone seem to indicate the route."

Karen tradition says that the chieftain who led the party stretched the staff in his hand and, as they crossed, from time to time a stone rolled up in a path before them to show the course they ought to take.

As for the date and time or era when the Karens made this crossing for their southward migrations there is no record within reach. But there seems to be a link fitting into the above move, which was recorded by $\mathrm{Dr}$. W. C. Dodds DD. in his book "The Tai Race." Dr. Dodd had served for 33 years as a missionary in China, Siam and Burma. From his experience, exploration and research he wrote about the Karens in his book thus:

The name Yûn is not a new name. It is the name by which they have been known by the peoples around them from earliest history. When the first great Tai migration drifted down from China as early as the sixth century B.C., the Ai Lao found the country east of the Salween inhabited by the Y On or Karens . . . the Karen kingdom seems to have been a large domain extending from the Salween to the Mêkong and probably as far south as Cambodia. Its riches were said to be immense. As the Ai Lao offered their allegiance to the Yan or Karen King he accepted it and allowed them to dwell in his land. In the early part of that century if not earlier they had built several large towns in what was then Yûn (Karen) country. Among these were Mueng Lem, and Chiengrung, Chientung, and Chiensen the oldest town in what is now Siam.

According to the local history I have read, in the year $543 \mathrm{~B}$.C. the Ai Lao by strategy threw off the Karen yoke in all these towns and surrounding districts. But they got thereby the Karen name according to Mr. Hallet. [William Clifton Dodd, The Tai Race (Cedar Rapids $\$$ Iowas Torch Press, 1923), pp. 250-51.]

Mr. Cross refers to a tradition, preserved by the Mons (Talaing) who he thinks are manifestly a more ancient people in further India than the Burmans\$ which he is of the opinion shows that the Karens were already in possession of the country to the east of the Bay of Bengal when the Mon themselves made their appearance in their southern progress as far as the promontory of Martaban.

After quoting Dr. Mason to the fact that when Gautama visited Thaton several centuries before the Christian era he found the Talaings occupying the country surrounded by barbarous people styled "Baloo," the Burmese equivalent for wild man or savages, Mr. Cross goes on to say that one can infer that the Baloos were the Karen from the fact that the island south of Martaban, known as Beloogyun or Beloo Island, was found to be almost exclusively inhabited by the Karens. Mr. Cross also points out that one of their ancient traditions distinctly gave their location on the Eastern side of a body of water, which they called "Kaw or Kho." the present inhabitants have lost the meaning of these words and the so-called body of water has become a mystery to them, so ancient is the tradition which refers to it. Yet the tradition, when examined, carries with it its own explanation of water: "Kaw," according to our ancestors, is a body of water to the west. They represent the bueros or hornbills migrating across it in seven days. As soon as the rainy season begins the hornbills migrate to the other side of the "kaw" to a country where it is the dry season, which is a seven days' journey. There they lay their eggs and raise their young; again when the dry season returns here, it is wet season on the opposite side and hornbills return across the "kaw" to this country, where they arrive after seven days' journey. 
Again whether kho-lo or kaw-lo (the river "kho" or "kaw") is a compound of the meaning of this expression and what river or body of water it refers to, we are now ignorant. It is preserved in the tradition that it is the most immense body of water in the world lying to the west and that it runs back towards its source. This tradition and one or two others which refer to the same body or bodies of water plainly indicate the Bay of Bengal. The difficulty appears in applying the word "lo," which is now used for a stream, to a body of water so large as the Bay of Bengal. But it sometimes refers to the ocean and need not be restricted to a river. It is the fact that the rainy and dry season exactly conform to the tradition. The wet season begins on the west side when it ends on the east and vice-versa, and perhaps the habits of the hornbills conform, for we do not remember having seen them on the eastern coast during the rainy season. From this tradition we infer that, from a period very remote, the Karens have occupied the country they now occupy on the eastern side of the Bay of Bengal. A marked circumstance which fixes the Bay of Bengal as the "Kaw" of antiquity is that it reverts or runs towards what is naturally taken to be its source. A strong current sets north from Achenhead or the upper end of the Island of Sumatra and passes the Nicobar Islands. This would be taken by the inhabitants of the eastern shore of the Bay as running back to its source. Since all the rivers of the Burmese Empire run directly to the south, and opposite to this current which is evident in the Bay. This body of water is said in tradition to be the largest in the world, showing that at some remote period the Karens either crossed it or had been familiar with those who had, as is also indicated in the tradition of the migration of birds and peculiarities of alternate wet and dry seasons.

No other body of water can answer to this description, and it is evident that no larger body of water had ever been seen by them within the reach of their tradition. We may conclude, therefore, that the Eastern shore of the Bay of Bengal has been their habitation from time immemorial and perhaps before the Talaings, the Burmese, and the Siamese Empire were in existence.

Other reasons adduced by Mr. Cross which may be given in favour of the idea that the Karens are the aborigines of at least of the South Eastern province of Burma are: Firstly the Burmese believe they are so. Secondly, the name Karen (m $q \&$ ) means first or aboriginal. Thirdly, the people bear out the character of aborigines in their simple and primitive habits and in their relationship to other dominant races.

The AI LAOS who came down with the first great Tai migration southward in the 6th Century B.C. found the country east of the Salween river already in possession of the Karens. It is therefore evident that the southward migration of the Karens took place before that date. The Salween river is not an obstacle that could not be crossed by the Karens into the plains of Burma: since their migration might have been motivated by the need of more fertile country, it would be most unlikely that they would all stop on reaching the Salween river. Therefore it is not unreasonable to assume that some portion of the leading elements had crossed into the plains of Burma before the 6th Century B.C., a fact which strongly supports Mr. Cross's adduction and the deep-rooted conviction of the Karens that their forefathers were the earliest settlers of Lower Burma.

In support of the Karen belief of being the first settlers in Burma, Mr. J. Dautremer (who was Consul for France in Rangoon long enough to get a good knowledge of the country in old Burma) in his book "Burma under B ritish Rule" as translated by Sir James George Scott, K.C.I SE., writes:

There is another race which has nothing in common either with the Burmese or the Talaings which inhabit the hilly country to the east of 
Burma, as well as some of the plain districts, especially Henzada. These are the Kayin or Hk'yin, whom the English called the Karens. They are still a very distinct race from the Burmans, who conquered them in the time of Alaungpaya, and who are correspondingly detested by the Karens. For the most part they are scattered clans, isolated in the midst of the conquering race, and it is only in the ranges east of Toungoo that they are found in a natural state. It may be assumed that the Kayin or Karens formerly lived under better conditions than they do now. Their language is absolutely different from that of the Burmans and the Talaings, and has quite a copious vocabulary, which enables them to express noble thoughts and seems to indicate a people of some culture. They assert that they formerly had a written character, and it is not unlikely that they formerly had a government of their own. It is not so very long since one branch, the Kayin-ni, or Red Karens, who live in the mountains, were independent. According to their traditions they had a very beautiful capital which the Burmese razed to the ground, and this city, they say, was in the plains, near Ava. A song, which is sung to the present day, says, "In the plains where our forefathers lie, walk with gliding steps" (that is to say, with solemn steps and slow).

No doubt the inveterate hate they have for the Burmese dates from the time of the overthrow of their capital. They have several times risen in a body to try to avenge themselves. It is, however, certain that they were not originally situated in Burma, and there is little doubt that they belong to the numerous and very scattered races which are classed together under the name of Hka, who inhabit nearly all the mountains east of Burma, the Lao country, the ranges which form the frontier between Burma and Yünnan, and even as far as the western mountains of Ssuch'uan. The word Hka means "slave" in Shan and it is hardly correct to refer to the "Hkas" as a race. The name is applied to all hill races by the Shans, irrespective of their racial connection with one another. What is certain is that there was an irruption of Hkayin [Karens] into Burma before there were any Burmese there, and that the Burmese destroyed their capital and subjugated them. At this period, about the fourth century of our era, the Burmese were called Pyu, and the Karens down to the present day still call the Burmese Piyã. [(London: Fisher Unwin, 1913), pp. 98-100. Emphasis not in original.]

\section{Characteristics of the Karens}

The Karens are a meek, peaceful, simple and credulous race with many of the softer virtues and few flagrant vices. Though greatly addicted to drunkenness, extremely filthy and indolent in their habits, their morals in other respects are superior tosmany more civilized races, so wrote Mrs. Judson many years ago.

The Karen, says Dr. Mason, is the antipodes of a Burman in every respect. The manners of the Burman are polished, winning, whereas the Karens are cruel and repulsive. Flattery is so foreign to his thoughts, that he has no words for it in his language. In another book Dr. Mason says, "A well read Burman has a mind like a schoolman of the middle ages, a repository of obsolete metaphysics and exploded science. A Karen knows nothing, but he acquires knowledge as readily as an Anglo-Saxon, detects sophism as quickly as the Master of Arts and requires the reason of things like one grounded in Euclid.s"

Rev. Norman Harris, also a Karen missionary for many years and who knew Karens intimately, made more or less the same remarks on the character of the 
Karens, in his book "A Star in the East." He also added that the besetting sins of the Karens of the present time are immorality and drunkenness. He attributed the cause of this backsliding from their high standard of morals to contact with other races from within the country and also from outside.

The author of this book, a Karen himself, considers that the observations made and recorded by the above missionaries are generally correct and applicable to the Karens of today. Within the memory of the author in half a century or so, it was most uncommon for a Pwo-Karen boy to marry a Sgaw-Karen girl or vice-versa, although they are of the same races but of different tribess let alone marry other races and foreigners. Illegal cohabitations even among the tribes and clanss would be such a disgrace to the family concerned that they would be socially cast out from the rest of the village and community to which they belong. Theft and dacoity were very rare if not unknowns A person only need leave some sort of sign to claim ownership on anything found which he could not take possession of at the time of discovery, and it would be strictly left alone by other Karens coming after him. For example a beehive or orchids which were not ready for the takings a few notches on the tree with a dah would be sufficient and assure possession of the thing found by that person. If it were of mushrooms on a piece of lands tying knots with grass in thesarea would assure ownership. But today, although this high standard of moral code can still be applied to the majority of Karens and dominant Karen areass it can no longer be trusted and guaranteed with somes especially those who live in towns and who get mixed up with other races and acquire all their vices but not their virtues.

Today some Karen parents will be only too happy if their children marry within the Karen races irrespective of tribes and clans. Once again the defaulters were mainly those who got sophisticated through other customs and people. Today there are Karen prostitutes, which would have been unheard of two or three decades ago. Thieves, yes, there are dacoits; and robbers, yes, they can do that too. In facts they even excel among all the dacoits and robbers ever known in Burma. A few years ago the author read in the papers that three Karen rebels robbed a (U.B.A.) plane which was carrying several lakhs of the Government treasury to a certain town in Burma. When he first read this piece of news he thought the Burmese Government was just trying to put out propaganda against the Karens, so that public opinion would be against the Karens. He could not believe that the Karens could do it especially when they were then No. 1 enemy of the Burmese Government. He could not imagine how those Karen rebels could get information of the treasury being moved that day, and how they could hide their pistols and grenades before boarding the plane. But they did it. He never believed that those robbers could be Karens until a few years later. He saw in the papers again that one of them surrendered. When he read that bit of newss he took his hat off to those three Karen boys. With all his educations trainings experience and years of service in the Army combined, he could not have come anywhere near that exploit if he was asked to take on that particular job.

\section{Book Tradition}

But the Karens have no book, or fragment of a book, to which they can trace their oral traditions handed down diligently from father to son in their songs. When Dr. Judson [an American missionary (1813)] entered the country, they had not even a written alphabet, but their fathers had told them that once they possessed the word of the eternal God, which gave them histories of the Fall and of the Flood, and bade them never worship idols. They say that the Prophet who had the charge of this book was reading it one day 
beneath a tree and he fell asleep, when a dog came and tore it to pieces. Then God was angry, and gave them up to evil spirits, or "Nats," of whom they are ever since in fear. . . . They have many beliefs evidently derived from the Old Testaments and some very remarkable ones, originating perhaps in other sources. They say that men had at first one father and mother; but because they did not love one another they separated, and their language became diverse, that:

"The Karen was the elder brother, And obtained all the words of God, God formerly loved the Karen nation above all others, But because of their transgressions, He cursed thems And now they have no books.

Yet He will again have mercy on thems And love them above all others

"God departed with our younger brother, The white foreigner. He conducted God away to the West. God gave them power to cross waters and reach lands And to have rulers from among themselves. Then God went up to heaven But He made the white foreigners More skilful than all other nations.

"When God had departed The Karens became slaves to the Burmans, Became sons of the forest and children of poverty; Were scattered everywhere. The Burmans made them labour bitterlys Till many dropped down dead in the jungle, Or they twisted their arms behind them, Beat them with stripess and pounded them with the elbow, Days without end.

"In the midst of their sufferings They remembered the ancient sayings of the elders, That God would yet save them, That a Karen king would yet appear.

The Talien kings have had their season;

The Burman lings have had their season;

The Siamese kings have had their season;

And the foreign kings will have their season;

But the Karen king will yet appear.

When he arrivess there will be but one monarch

And there will be neither rich nor poor

Everything will be happys

And even lions and leopards will lose their savageness.

"Hence in their deep afflictions they prayed, If God will save us, Let him save speedily! We can endure these sufferings no longer. Alas! Where is God? Our ancestors said that when our younger brothers came back, The white foreigners 
Who were able to keep company with God, The Karens will be happy.

"Our ancestors charged us thus--

'Children and grandchildren,

If the thing comes by land--weep

If by water--laugh.

It will not come in our days,

But it will in yours.'

Hence the Karens longed for those

Who were to come by water $s^{\prime \prime}$

Another remarkable tradition among the people was as follows:--The elders said, "When the Karens have cleared the Horn-bill city (the site of an old city near Tavoy, which the Karens were called on to clear occasionally, when the trees grew up over it) three times, happiness will arrive, so when the Burman rulers made them clear it the last time, they said among themselves, "Now we may suppose happiness is coming, for this completes the third time of clearing the Horn-bill city," and true enough, for before they had finished, they heard that the white foreigners had taken Rangoons

Dr. Judson had lived fourteen years in Rangoon, preaching about the eternal God, in whom none would believe, while the poor unnoticed Karens were continually passing his door and singing the same truth by the way--

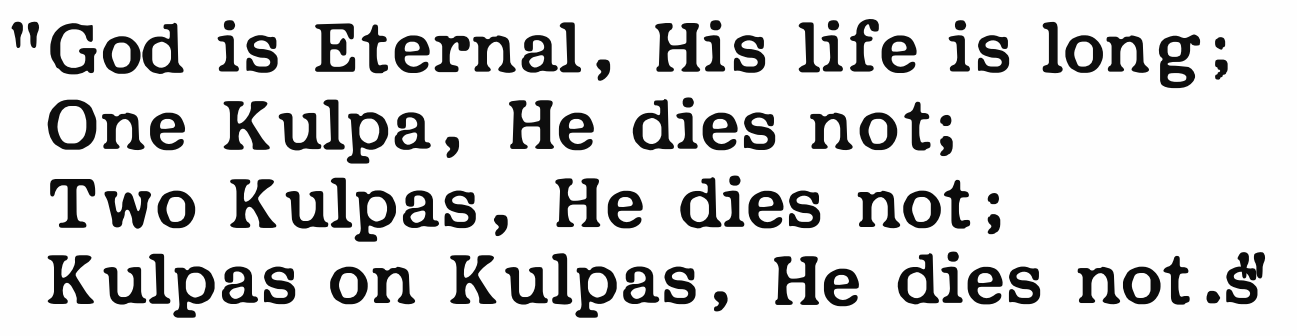

The first Karen who attracted the Missionary's attention was Kothahbyu [Saw Tha Byu], a slave, whom he took into the mission family as a free man, and after instructing him in the Gospel, baptized him [in the year 1828]. Ko-thahbyu [Saw Tha Byu] then became a remarkable pioneer preacher to his countrymen, in one village after another, for thirteen yearss and raised up other Native preachers. [Mrs. Mason, Civilizing Mountain Men (London: Nisbet, 1862), pp. 366-69.]

The above traditional beliefs had caused these wild tribes to accept Christianity so readily, like a prepared field ready to receive the seeds. This fact marked the open path for the missionary of the Book and how wonderful it was to find that it was for nothing else these people are waiting, said Mrs. Mason.

"Have you brought God's book?" said the simple timid Karen villagers of DongYhan to Mr. Wade, a pioneer missionary among Karens. This was the very first question they asked the white foreigner whom they fully believed would bring it back to them; and as it happened from the last century and now we are just beyond the middle of the 20th Century, and there are yet some more prophecies from the Karen traditions, still to come. 


\section{CHAPTER 2}

\section{EARLY LIFE OF THE FOUR-FOOT COLONEL}

From among these simple Karen people with such background and traditions, was born a Four-Foot-Colonelnto-be on 11th November 1906 . He belonged to a Karen peasant family with average means in terms of the particular time and society he was inn It could not have been much of a standard of life in comparison with our present time. From his elders he learned that he was rather ill-tempered and cried too much for the liking of his family. The only time he seems to have been in a good mood and cheerful was when he was given a long cold bath in the morning, when he would suddenly forget his irritationsn He would then turn into a docile and cheerful child who would then smile and chuckle all the time that his mother and other female members of the family would oblige him with such cold baths. Because of his fondness of water his whole family called him "Po Yay" or Mr. Water.

Mrn Water met misfortune from a tender agen His mother died of cholera when he was hardly a year old. In the days of such ignorance of hygiene and lack of medicine and precautionary measures in Burma, such epidemics were the order of the day. After his mother's deathn he was brought up by his maternal aunt assisted by his elder sister who was then hardly fourteen years oldn His father who was in his early forties left all the care of Mr. Watern other than providing the means, to his aunt and sistern

\section{Village School}

He remembered being taken to a village school for enrolment in a village where his aunt had gone to live, having been married by thenn There he was again left in the care of his aunt who by now had a son of her own and who no doubt had come to know what a mother's real love and affection was. This turned out to be a real blessing for young Po Yay ( $\mathrm{Mr}$. Water) who received all the maternal care and affection of a normal childn There were sixty to seventy children in this school, ranging from kindergarten class to fourth standardn There were only two teachers; both were women in their thirtiesn The curriculum of the village schools was just as comprehensive as the schools of the present day, if not more sensible. Karen language and scripture teaching formed the two most important subjects for all Karen schoolsn and today are apt to be neglected in some of the Karen schools. After he passed the third standard from this school, his father sent him to American Baptist Mission Pwo Karen School at Basseinn

The above was an Anglo-vernacular school where both English and Burmese were taught. Having learnt no English at the village schooln he was put back in the second standardn but with his perseverance he managed to get a double promotion and passed the second and third standard in one yearn The fourth standard examination had always been government controlled and most young people found it to be a stumbling blockn but Po Yay managed to pass it in one year in spite of his double promotionn 
In the fifth standard, he was again promoted to the sixth at half term and passed it in the same year. When he came to the seventh standard, which was also a government controlled examination, he could not make any headlines like he did in the lower classes. He just managed to toe the line and sometimes just above average. He was now up against not a few second and third year students in the same class, who naturally knew more than he did, since they had to go through the same text books. However he managed to pass it in one year, although some of his brighter contemporaries failed. There is an old saying in Burma that to be a successful man, one must have three things: "Kan, Nyan and Wiriya,s that is luck, wisdom and perseverance. It might be that Mr. Water had all the three, and no doubt a big percentage of Kan, or luck.

\section{Government High School}

Having passed seventh standard he had to leave his mission school as it was only a middle school. There was one other Karen Mission High School in the same town, but he chose to join the government high school instead ass in those dayss it had a higher reputation in its standard of English and percentage of passes.

In keeping with his past successes, he was doing pretty well in the eighth standard, passing his monthly and quarterly examinations. One day a recruiting party from the Burma Rifles turned up in the town. On seeing the recruiting of ficer, his N.C.O. and men swaggering about in their uniforms, his childhood dreams and ambition of becoming a soldier once again loomed ahead and gradually obscured all others. He ran away from school and joined up in the Army. Although under age and slightly short of the prescribed height, which was $5 \mathrm{ft}$. 2 inches, he was accepted all the same for the solid build with which most Karens are blessed.

On learning about the disappearance of his son from the school, his father had quite an anxious time. His father finally traced him insthe Burma Rifles, whereupon he sent an imploring letter to the Commanding Officer for the release of his son from the Army, with the plea that his son was still under age and that the boy be allowed to continue his studies. By this time, Po Yay had been in the ranks for nearly three months sweating hard on the square, learning soldiering. One day he was summoned to his Commanding Officer's office having no idea what it was all abouts With all his three months' trainings he mustered all the smartness and clicked his heels and saluted worthy of a Guardsman on reaching his C.O. He was informed about the letter from his father, who was anxious for him to return to school and continue his studies. When he was asked by his C.O. if he wished to go back to school, he shyly replied "Yes Sir.s" He was discharged as unlikely to become an efficient soldier, the only para of the regulation that could be applied to release him. To say he was under age would mean a crime for fraudulent enrolment. He went straight back to school, and even though he had been away from school for nearly four months, he still managed to pass his eighth standard at the end of the term.

Food at the Mission schools was bad enough, but in the Burma Army those days it was worses To make matters even worse the rationswas half Burmese and half Indian. Cooks of the Burma Rifles had not the foggiest idea how to cook chapatis, and as a result it was either uncooked or burnt. With good curry of meat, fish or even vegetable, it still wouldn't be too bad to the palate, but with such watery dhal curry as prepared by these cooks, it was most difficult to swallow. No doubt this was the factor thatsinfluenced him most to return to school. Evening meals were invariably Indian ration that was burnt or uncooked chapatis and watery dhal curry. To go to bed half full and wake up hungry, and go to 
parade with an unsatisfied stomach was most demoralising. This experience is not without its valuable lessons. It was this experience that always reminded him throughout his service to see that his troops got square meals whenever possible.

When he came to the ninth standard, he was still doing fines keeping well above average and passing his required examinations. Then came the half term break for three weeks, on the return from which Po Yay and the like always got some money from home for school fees and books etc. At this particular time he was most restless. Coincidentally one of his most intimate and best friends was also in the same frame of mind. Po Yay was bent on rejoining the Burma Rifles, and his friend Henson needed little or no persuasion. One early morning with such pocket money as they had, they left Bassein for Maymyo to join the ranks in the $10 / 20$ th. Burma Rifles which was the training battalion. Unfortunately when they got theres they found out that recruiting was closed and would not open for another two months. With their meagre meanss which by this time had nearly run out, it was quite a problem for them, how to hang on until recruiting opened. Returning to their homes and school was out of the questions especially for Po Yay who had done this twice. Fortunately the latter knew one of the Jemadars, a Viceroy Commissioned Officers who took care of them, thus saving them from falling into unpleasant circumstances.

In those days it was the fashion for the Karen boys to have English names; what other people called "incongruous names, $\$$ specially for those Karen boys who joined the ranks. That's how Po Yay got the name of "Smith,s" a name with which he had no connection whatsoever. It so happened that, prior to their departure from Bassein, there was a show in one of the cinemas. In this show he was particularly impressed with the feats of a strong man by the name of Mr. Smith. Hence, it was that he picked this name for his Army career. This change of name created many amusing incidents for the mischievous boys, particularly with two boys who were enrolled in the same batch. One rather burly and hefty chap was named by them Eddies after the strongman Eddie Polo who was well known even in Burma in the cinema world at that time. The other, whose name in Karen was "S'B wa" meaning whites was named "Whitey." These two boys were totally illiterate and as a result either one would answer for the other or else both would answer at the same time at roll calls or at any other time when it was necessary to check names. It took several months before the two boys settled down with their respective names.

Promotions were comparatively rapid for Smith and Henson, compared with otherss at that time owing to the need of educational instructors. It took them about six months to complete their recruit training and become full-fledged Riflemen. A stripe each in one year, and Corporal in two years, a Havildar or Sergeant in three years, when for the first time the interest and advancement of the two best friends clashed. There was only one vacancy for a Jemadar or a Viceroy Commission Officer for Education Officer of the battalion. 


\section{CHAPTER 3}

\section{A VISIT TO ENGLAND; SERVICE IN THE RANKS; THE INDIAN MILITARY ACADEMY}

Both were qualified for that promotion. The Adjutant, Captain W. E. Rivers, who was to make the recommendations to the Commanding Officer, would have liked both to be promoted had there been two vacancies. But there was only one, and he really was in a dilemma, whom to choose. By virtue of their enrollment numbers Smith was senior to Henson, otherwise all their previous promotions were on the same days and dates and came out in the same orders. From all the training schools to which they had been sent, both came back with equally good reports. Both obtained Distinguished Certificates from the Small Arms Training School, where most members of the Burma Rifles failed because of language difficulties. All instructions were then in Indian (Urdu) which was absolutely foreign to Burmese. From the Army School of Education Henson definitely scored better. To counterbalance that, Smith had done so well at the Small Arms Training School that he had to go back there as an Instructor for one year in spite of his C.O.'s strong protest at not being able to spare him. A potential Jemadar must at least be qualified from this school, for without a certificate from there no one could be promoted.

On completing their recruit training both were drafted to $2 / 20$ th Burma Rifles, which was then stationed at Taiping, Malay States. Soon after their arrival in this battalion, they attracted the attention of the Adjutant Captain Rivers, son of Revd. E. E. Rivers, the Vicar of Eltham, S.E. London. Worthy of his parentage, he was a very good Christian who took a great interest in religion. He used to organize church parades on the same lines as the British units, although there were no such rules and regulations for native battalions. He elevated the Karen Pastor to the equal of native officers, and found his waysto pay and provide the Pastor with appropriate status. According to the Indian Army rules and regulations then in force, a religious teacher was classified as a follower, a term usually applied to cooks, sweepers and private servants of officers, which was most inappropriate for a religious teacher. Captain Rivers was very fond of these two boys whom he used to call twins, as the two were invariably together whether on parade, in canteen, cinema or church. The fact that he could converse with them in English was no doubt the prime reason for his feeling of closeness to these two particular boys more than with any others under his command. He often organized bathing parties at one of the nearby waterfalls, where they would have picnics, sing-songs etc. In all these parties Smith and Henson were invariably present, and often acted as interpreters when the Captain's native vocabulary failed him. As a good Christian, he was also interested in the uplifting of unprivileged persons. He would always correct and teach the two boys in English, which was most important for advancement or promotion. When Captain Rivers was in such a dilemma as to their promotion to Jemadar he was just due for furlough. One day he sent for both to his office and told them exactly what was on his mind. That was he would. be equally glad and sorry for either of the two to be promoted and left behind. After which he put forward a proposal, for one to take promotion and the other 
to accompany him ostensibly as his language instructorn but mainly for furtherance of education for the one that accompanied him. Smith jumped at the invitation for a visit to England with a view to acquiring more educationn knowing also of course that Henson was brighter than himself. Just about that time rules and regulations came out that native troops from the ranks could obtain the King's Commission after attending the Royal Military Collegen Sandhurstn for which the following qualifications were requiredn-

(1) Must be a Viceroy Commissioned Officer and under 25 years of age.

(2) Must have passed the Army Special Certificaten a course equivalent to matriculation standardn but with some additional military subjectsn such as map readingn military historyn citizenship etc.

(3) Must be selected by a Selection Board.

It was thus decided that Henson was to be promoted and Smith was to go on leave with Captain Rivers. As stated previously, Henson was the brighter of the twon He sailed through his examinations for Army Special Certificate in the first shot and under his own steam while Smith had to do it twice. Soon after Henson passed his examinationn things were set in train for him to go to Sandhurst and also for Smith to take over from him as Education Officer "Jemadar."

Henson got into the College as easily as he passed his exams. At the Collegen he rose to the rank of a Corporal Cadet which was the highest rank granted to coloured cadets at Sandhurst at that time, he was told.

\section{Indian Military Academy}

About that time there were a good deal of hue and cry from Indian politicians about Indianization of the Indian Army. This resulted in the establishment of the Indian Military Academy at Dehra Dun. Smith by this time had become a Jemadar and was still within the age limits for going to Military Collegen but he still needed to pass the Army Special Certificate. Therefore he was sent to Kitchener College, Nowgong, which was in fact a preparatory course to enter the Indian Military Academy at Dehra Dunn

Smith passed in his first attempt at Kitchener Collegen gaining distinctions in four subjectsn There were to be forty cadets in the very first term in the Academy, fifteen from the Army, fifteen from civilians selected through competitive examinations and ten from State Forces. Having stood fourth at the Collegen it was pretty certain that he would be included in the fifteen. Moreovern he was the only one from the Burma Armyn which was then part of the Indian Army. In fact he got in without even appearing before the Selection Board. After the examination at the College all the students were returned to their respective unitsn except Smith who was to remain at the College and appear before the Selection Board theren Through an oversight, he was also sent of to his unit which was then stationed at Mandalay. The mistake was discovered only when the Selection Board arrived at the College, but Smith was well on his way to Calcutta. A telegram caught up with him just as he was about to embark on a ship to Burman with instructions for him to return forthwith to the College for an interview. It took him nearly a week to get back to the College; thus the Selection Board went away without seeing him.

The day before he left for Calcutta the Commandant Lt. Col. Sandernam had invited him to tea and given him some useful advice on the life of a cadetn $\mathrm{He}$ therefore had little doubt that the Commandant would come out with a strong recommendation for him to the Selection Board, which no doubt was the case and the Selection Board had taken his word for what it was worth, and Smith did not 
appear before the Selection Board. For this achievement he was most grateful to Captain Rivers for all his helps advice and encouragement.

\section{The Rivers Family}

The year spent with this noble family taught him many finer things of life which one can only learn through personal contact and experiences and not from books or acquisition of University degrees. In those days English etiquette was a very useful thing to know, and the most useful thing for him was to be able to speak English fluently.

The family consisted of the Revd. E. E. Rivers, Mrs. Rivers, Captain Rivers, and two sisterss Charis and Veras who are the eldest and the youngest of the family. To him they were most charming and lovable people. They were real Christians in the true sense of the word. Even though young Smith (Friday) to them was only from the ranks and a native at thats yet they never treated him as such. From the day he arrived at the Vicarages he was more or less adopted by the whole family and relations for the duration of his stay. The sweet and charming smiles of Mrs. Rivers are still vivid in his mind unto this day. When she died some years later, he was told that a paper cutting of his visit was found in her treasure box. Once when he caught a slight colds the two sisters looked after him like they would to a child. They made him remain in bed and would scold him if he got up too much or if he sat in the draught. Out here in the East people take little or no notice of such trivial ailments. Unto this day he is still in touch with that family.

\section{Indian Military Academy}

Now that there is a Military Academy at Dehra Dun, all future Indian Army officers will have to be the product of this institutions except of course B ritishers who would still do their training at Sandhurst. Although Sandhurst has a long and established reputations the Academy at Dehra Dun is by no means inferior. Smith has no reason to regret not being able to go to Sandhurst, as will be seen later. It was October 1932 when forty cadets of the very first batch in the history of the Indian Military Academy turned up at Dehra Dun to sweat for their Commission.

It was a bright, sunny morning when they arrived. On their arrival, they had to report to their respective Company Commander's office, where the of ficer checked and took down various particulars of each cadet. The cadets naturally tried their best to impress the of ficer with their dress, speech, carriage etc. Smith naturally put on his best uniform and reported to Major D. T. Cowan M.C. with all the smartness and polish that he had learnt so far.

Major Cowan came from the Gurkhas, whose uniforms were more or less identical with the Burma Rifles. In appearance the Karens and the majority of Gurkha tribes differ very littles a fact which might have influenced the Major to some extent in making his decision in favour of Smith. He never forgot the first conference given to them by their Coy. Commander in one of the anterooms. The cadets were all keyed up to hear what the officer had to tell them. Without any fuss and explanations Major Cowan first announced that G. C. Smith would be No. 1 (or Senior Cadet) in his Company, responsible for all the discipline in quarters and anywhere where officers were not present, and that the rest must submit to his authority and cooperate with him. This was most unexpected and indeed it was a very pleasant surprise for Smith. The officer went on to explain what he expected 
from them on parade or off parade and concluded his conference with a warning that he would give them only two days' grace to forget all their soft school or civilian life and come up to his expectations.

At the end of the conference each was given some papers on which were instructions to be filled out by individuals, on completion of which the senior cadet was to collect and hand them back to the officer before lunch. Looking through his papers more or less casually, Smith filled out the particulars required, but clean missed seeing that particular instruction that he was to collect and return the papers to the office. Having filled out his forms, he took off his coat and threw himself almost spreadeagled on the bed, to relax until lunch time, quite pleased with himself, but realising little what a shock was in store for him in half an hour's time or so. Having travelled for nearly a week without rest and sleep, he felt somewhat tired and had fallen half asleep when there were loud and repeated knocks on his door. He heard someone call out his name to which he answered definitely in a tone of some annoyance such as, "Who is that?" and "Come in.s" The intruder was no other than his Coy. Commander, who in the same breath said, "Damn it! You have not handed in the papers" and that he had been waiting for them for quite a long time. It is needless to tell the readers that Cadet Smith nearly fell off his bed and evaporated with shame and fright for his uppishness and omission. He was, however, let off only with a mild rebuke. This unfortunate incident turned out to be a real blessing in disguise throughout his training at the Academy. Thence, onward, he really went hard at everything thoroughly and methodically, with the above incident always prodding him whenever there was the slightest inclination to relax.

\section{The First Term}

The forty cadets were divided up into two Companies " $A$ " and "B,, $\mathrm{S}$ each of twenty cadets. Although the Companies were small the competitive spirit between the two was very greats Smith was in "B" and led his Company in all the competitions such as drill, physical training, riding, athletics etc. "B" Company won the championships consecutively for three terms, running away with nearly all the trophies. Smith was actually "Jack of all trades but master of none.s" He did not excel in any individual event, but was good enough to secure a place and make up a team. He took part in nearly all teams and individual events, except cricket which he knew nothing about, having no inclination for that particular game. Being only a shade over $5^{\prime} 3^{\prime \prime}$ tall riding was definitely not his hobby, as taught by the cavalry officers. His short legs could hardly be comfortably astride those big horses leave alone gripping them like the Indian sowars and keeping position like them. Jumping lanes and bumping trots were the two things he dreaded most in riding. Jumping high fences placed well apart did not worry him as much as low hurdles placed at close intervals. In this type of jumping he would often be off his saddle and on the horse's neck in one jump and back again in the saddle in the next and sometimes would find himself on the ground. On the other hand he enjoyed riding on his own, and cross country riding when no one bothered about gripping and keeping positions as he rode mainly with balance. This was what he got from his equitation officer on "riding": he rides with plenty of grit, but his small stature prevents him from becoming a good rider.

Boxing was another sport which he did not like very much at the Academy. Because none of the other cadets were under featherweight, and he hardly weighed bantamweight, his opponents always had the advantage of weight and reach. He fought only three bouts in Company championships in which he won two by T.K.O. and lost one on points. In this particular fight his opponent was too tall for him 
and invariably got him on the face or body whenever he tried to close in for a knock out, which was his only chance of winning. His cadet promotions were even more rapid than when he was in the ranks. He became a Gentleman Cadet Sergeant before the end of the term, which was under six months.

On the 10th December, 1932, the C. in C. of the Indian Army, Field-Marshal Sir Philip W. Chetwode, came formally to inaugurate the Academy, which was also his first inspection. The Adjutant and the Regimental Sergeant Major put the cadets through various drills needed for the occasion and made the senior cadet take over the parade at intervals, as he would be the person to take the parade on the day of the inspection. How Smith looked forward to this inspection, because he had always been fond of ceremonial parades in the battalion, such as for King's birthdays, Armistice days and the New Year's parades etc. How he envied the C.O. and Company Commanders bellowing out their orders in succession on these parades. Then he was only in the ranks and invariably had to fall in to the near or extreme left, whenever the order "Tallest on the right, and shortest on the left--Company-size, $\$$ was given. Now he would be commanding the parade like the C.O. and Company Commanders, giving out orders for "General Salute,s" marching past and various others that follow the General's inspection. How he looked forward to swaggering before the Commandant, the officers and all the spectators, mostly relatives of cadets, who camesfrom many parts of India to see their sons and brothers on such occasions. He would remain awake for many hours at night memorising every detail and the orders he would have to give and carry out on the inspection. To give orders with one's back to the parade and also carry out the same movements required some memorising. The Chief Instructor was Regimental Sergeant Major Fullbrook who was a near six footer, whose thunderlike words of command fascinated Smith no end. Each evening in his leisure hours Smith would quietly slip away to the nearby jungle to imitate the Sergeant Major in order to cultivate the same words of command, not taking any consideration of his ages experience and size compared with his own. As a result, he completely lost his voice a few days before the $C$. in $C$ 's inspections However with gargling and swallowing pastilles almost continually he regained just enough voice to take the parade. The inspection went off fairly well with words of praise and congratulations from his contemporaries and the Adjutant and Sergeant Major as well. He was much encouraged by these compliments although some of them might have been made merely for the sake of courtesy.

\section{The Second Term}

There were similar promotions made in "A" Company. But in that Company for one reason or another the Senior Cadet had to be reselected, thus giving Smith a clear lead as the most Senior Cadet in the Academy, which he managed to retain throughout the course. Now there were eighty cadets and the first batch of cadets felt quite pioneers. Officers, who were in constant contact with them on parades, games or at dinners, either at the cadets' mess or officers' houses on invitations, often in their own quiet way imparted to them their experiences at the Royal Military College at Sandhurst. One thing that interested them most was the ragging these officers had had there, specially the freshers. The pioneers were not only quick to learn about them but also to put them into practice. The first ragging that took place there was in the form of fire alarm. One very cold winter morning, one of the pioneers who could blow the various bugle calls had the bright idea of getting everybody out of bed by blowing a fire alarm about four in the morning. Nearly all cadets turned up in their pyjamas, some carrying fire extinguishers, and those who were not so fortunate had to carry fire buckets full of water and 
icy cold. The majority of the eighty cadets were caught in this ragging including the senior cadet Smith, but he was quick to learn. Having got out of his room and seeing no fire in the vicinity he took no further action and went back to his bed, pretending not to hear the bugle or know anything about it. When there was no sign of fire and no responsible person on the scene, it dawned on those who were caught that it was only ragging after all, and all went back to their rooms, no doubt with some abuse on their lips. Winter at Dehra Dun can be pretty cold, and to be out of bed in pyjamas at that unearthly hour was not at all a pleasant joke. However the boys took it in the right spirit and nothing much was said afterwards. Before winter was over the culprit of that first ragging came to be known by some of the pioneers who had been caught in it, and Smith was told later that four or five of the pioneers gave the culprit a good ducking one early morning in his own long bath. There was no doubt that he too took it in the right spirit as there was no complaint and nothing was said about the incident. By the end of the second term Smith became the senior under officer which is the top rank of the cadets. By this time nearly all other cadets of the First Term were promoted to various ranks from Lance Corporal to Sergeants to fill up the establishment of the cadet ranks. One under officer was also made in "A" Company.

\section{The Third Term}

The number of cadets had swollen to 120 by now. Training for the first batch of cadets or the pioneers continued with unflagging enthusiasm including more practical works. They were taken out for a month's camping, where they learned field work, patrolling and other basic training in tactics such as attacks and defence etc. Visits to various units and installations were also included in the programme. The most important event in this term was the visit of The Viceroy of India, The Earl of Willingdon. The same preparations were made as in the case of C. in C's visit and, in addition, a Royal Salute would be given to the Viceroy. A band was borrowed from one of the units for the March Past. Smith now dressed almost identically with of ficers complete with Sam-Browne belt and sword, but with red-tabs on his shoulders instead of pips or stars. He felt really grand in his own imagination, and his feet hardly touched the ground as he swaggered about on parade. By now his throat was so hardened by his continuous practice, that he could almost bellow like Sergeant Major Fullbrook. There were more spectators; invited guests alone would be well nigh a thousand, and there might be at least double that number from the town itself who came to see the Viceroy and the parade. As both cadets and Smith had more practice and confidence by now, the parade concluded with more precision. Once more praise and congratulations came forth from officers and friends, including the Viceroy and Lady Willingdon themselves. As the Senior Cadet, he was given the privilege of entertaining and sitting near the honoured guests who came to the Academy. On this occasion lunch was served in the Main or Chetwode Hall as the Cadets' Mess would have been too small to take all the cadets and their guests. After lunch Lady Willingdon insisted that all cadets be introduced to them individually. This was done, after which they departed with the three cheers from the cadets led by their Senior Under Officer.

\section{The Fourth and the Last Term}

Trainings continued with the same intensity, but there were more outdoor exercises with or without troops. Cadets were given their turn to command platoons and companies when drilling on the squares or on these outdoor exercises. They were given thorough grounding in handling troops up to platoon and company level. 
Once again ragging played an important part at this times which nearly caused the downfall of the Senior Cadet Smith. On one April 1st morning which happened to be also Sunday these boys went a bit too far in playing the April Fool without Smith's knowledge, and he was confronted early in the morning by the Adjutant who questioned him all about the ragging that had taken place during the night, and who was responsible for blocking the gate of the Second in Command with trophy guns, thus preventing him from going to early morning service. The officer concerned was really furious. There was nothing else Smith could do nows but apologise and admit that he knew nothing about it, with a promise that he would be responsible for seeing that no such thing took place in the future. It was a fact that he knew nothing about it. Had he known about it, he would certainly have stopped the one preventing the officer from going to church. The $C$. in $C$. paid a visit once more before the end of the course. The number of cadets now swelled to the full establishment. " $C$ " and " $D$ " Companies had also been formed. With their increasing number and experiences the Inspection Parade became even more interesting and impressive for the spectators and also for the cadets themselvess especially for Smith who by nature likes pomp and show and who was the central figure in all these shows.

\section{The Passing Out Parade}

They knew that there was a sword of honour for the best all-round cadet. Academicallys there was not the least hope for Smith because he could just manage to obtain pass marks and was only about average in position. But when it came to practical work, such as digging trenches, putting up wire fences, climbing hills and swimming streams, where it called for stamina and dash he would invariably come out first. In physical training and physical efficiency tests he was the first to win the (blue) or special class. Football was another game in which he managed to win the colours.

All cadets of that particular term were the pick of the cream of Indian youths. All came from families of good standing, education and backgrounds and not a few were educated in England, some with excellent military traditions behind them for several generations. Even from such a crowd Smith had reciprocal respect, brotherly love and all the cooperation that was needed, even though he was a foreigner to them. The day before the Passing Out Parade there was a guest night at the Cadets' Mess at which all officers of the Academy were present. Even up to that time, no one knew who would be the winner of the sword of honours There were not even rumours about it. Apart from another Under Officers there were at least two Sergeants who had changed places as first and second in examinations for the last four terms. It could easily be one of them. At the end of the dinner Smith was quietly warned by his Company Commander Major William not to spoil the parade through disappointment if the sword was given to someone else. He naturally took this hint that he was not the recipient of the sword because as a Company Commander Major William would have been consulted. He was however quite content because of his low achievement in academic subjects. By this time he could almost compete with Sergeant Major Fullbrook in thundering out words of command. The Parade started well and ended well. There were even more spectators for this parade, specially guests and relatives of cadets who came from all over India.

The parade was at "Easy," to hear the speech to be given by the Commandant, $B$ rigadier L. P. Collins, and to witness the presentation of the swords which was now brought on the square and placed on a table. The details of the speech cannot now be remembered but broadly speaking it was a pat on the back to the officerss and for the hard work and cooperation between the officers and cadets and the 
successful conclusion of the very first course in the history of the Indian Military Academy. After which he expressed his satisfaction and gratefulness to all concerned. Having concluded his speech, he moved a bit closer to the table where the sword lay, and announced that Smith was the winner of the sword of honour. Once again it was the most pleasant surprise for him, as he had taken it for granted that the winner would be someone else from the hint he received. Congratulations poured in from all round after the parade, and last and most important of all, some came by wire a day later from the C. in C. himself, F.M. Sir Philip W. Chetwode. He was very happy indeed and, needless to say, feeling quite pleased and important about himself for all the achievements. In spite of his weakness in academic subjects, he was given the sword. No doubt more stress was placed in grading on other qualities needed for an officer, such as power of command, reliability, dash and endurance etc. he felt then.

As was the custom, all those who passed out and were to leave the Academy were dined out by all officers of the Academy. Smith was the guest of honour and was given the privilege of sitting between the Commandant and his Company Commander (Major William), who in the course of conversation during dinner seriously remarked, "Well, Smith, you are a hell of a chap at the Academy, but you will be only a Second Lieutenant after you leave here.s' How true this remark proved to be for many years later in his career.

His life as a cadet was the best time of his career. He had no reason to regret not being able to go to the Royal Military College, Sandhurst. There he would have been just a Gentleman Cadet or, at the most, a G.C. Corporal which he was told was the highest rank a coloured cadet could attain at that College. But here he was the top dog in the history of the Indian Military Academy. Training, if not superior to Sandhurst, was by no means inferior. There was a good deal for him to thank his incongruous name of Smith. No one would expect him to have such a name and quite rightly too. During his visit to England, one paper after giving a short account of his visit concluded thus, "His name is just Smith," and the other said, "His name unexpectedly is Smith.s" This name, combined with his talent and ability to mix freely and take part in nearly all games and athletics, made him well known among his contemporaries and senior officers wherever he might go, even before others could be remembered by their names.

In spite of his gratefulness to this name he found it necessary to take on another name. As Smith is an old English family name, to carry this name with no connection whatsoever, became rather awkward as he gained more knowledge of English customs, etiquette, and ways etc. Sometimes it was not a little embarrassing when he was asked by some untactful person how he came to be known as such. Therefore, before the end of the course, he decided to have a name that belonged to him and that, if one must copy the Englishman, would copy it in the correct way. So he took on his father's name "DUN" as a family name and kept " $S$ " as his initial or Christian name, with a view to camouflaging it; but it did not work out quite that way, and he became known by the double-barrelled name of Smith-Dun instead. It was unusual in both cases. It was just as uncommon to have a family name in Burma as to have Smith for a Christian names In Burma people do not have family names. Children are named individually as their parents may decide, and thus a family of five, ten or more, all have different names. Of late some families are adopting family names and no doubt it is a very sensible thing to do.

\section{A Glimpse of the Indian Military Academy}

The Statesman of India gave a very comprehensive account of this institution when it reached its silver jubilee in the year 1957. It may be of interest to some 
readers to know how it started and how much it achieved in the three decades of its existence. Although the Cadets arrived in October 1932, it was only officially inaugurated on 10th December, 1932 by Field-Marshal Sir Philip W. Chetwode and also his first inspection as mentioned by the author in the foregoing paragraphs. The writer is indebted to the Statesman for being able to quote some extracts.

Standing in the Chetwode Hall, one's attention is drawn to an inscription of the following words of advice to would-be officers of the army uttered by Field Marshal Sir Philip W. Chetwode:

1. The safety, honour and welfare of your country come first always and every times

2. The honour, welfare and comfort of the men you command come next.

3. Your own ease, comfort and safety come last and always every time.

These three principles written on the oak panelling of the staircase of the eastern entrance of the hall have been continuously brought to the minds of the Cadets who have since passed out of the institution as full-fledged officerss They have all selflessly lived up to this code of conduct, and so it is to be hoped, the present and future Cadets will for all time to comes

\section{Gallantry Awards}

One also cannot fail to notice the roll of nearly 100 ex-cadets who won various gallantry awards for heroic action in World War II, with the name of B rigadier P. S. B hagat, V.C. and the late Major Sam Nath Sharma among them. Looking in another direction there is the roll of honour with the 200 odd ex-cadets of the Academy who died in the service of the nation.

Situated on the outskirt of Dehra Dun in Prunnugar amidst picturesque mountainous surroundings, this institution completed its useful and eventful existence of 25 years on December 10, 1957s It traces its origin to the persistent efforts made by our national leaders from time to time for the Indianization of the Defence Servicess Until after World War I Indians were not eligible for what were then called King's Commissions in the Army. All that they could aspire to were Viceroy Commissions and it was these men who formed the connecting link between the rank and file and British officers.

It was not until 1920, following the Montague-Chelmsford reforms that King's Commissions became obtainable by Indians either by passing an examination held every six months in India and qualifying as Cadets through the Royal Military College Sandhurst or the Royal Military Academy or by the bestowal of honorary commission from Viceroy Commissioned officers who had rendered distinguished services This practice continued till 1932 when the last batch of Indians emerged from the U.K. training institutions.

Before admission to Sandhurst and Woolwich were thrown open to Indians a school was started at Indore in October 1918 in order to provide Cadets with necessary military background to assist them in obtaining vacancies from out of the ten allotted annually in the B ritish institutions The Indore School was organized only as a temporary expedient to meet the special need of war, and before it was closed down, after functioning for a year nearly 40 Indians had been granted King's Commissions.

The main draw-back of this system was that only a handful of Indians could hope to hold commissioned rank, the majority of officers being still B ritish. However, the Skeen Committee appointed in 1926, with Lieut. 
General Sir Andrew Skeen Chief of the General Staff as Chairman to examine the feasibility of setting up an "Indian Sandhurst" recommended that the Army should be progressively indianized.

\section{Steady Indianization}

As a first step the Indian Military Academy was set up in 1932 at Dehra Dun which has a temperate climate all the year round. Fortunately the imposing buildings constructed for the railway staff training college there readily became available to house the Military Academy. The then Commander-in-Chief Sir Philip Chetwode formally opened the Academy and B rigadier L. P. Collins was appointed its first Commandant. Though designed for 150 Cadets the first intake was only 40 Cadets including ten from the States who after getting their Commissions returned to their respective States.

The first batch of Cadets passed out of the Academy on December 22, 1934. Among them being B rigadier B hagwati Singh, Brigadier S. F. H. Z . Manekshaws B rigadier Harban Singhs B rigadier Pritain Singh, the late Brigadier K. L. Atals and Mr. Mohan Singh of Mr. Subhas Boses' "Indian National Army". The sword of honour for the best all-round Cadet went to Senior Under Officer Smith-Dun who rose to the position of free Burma's First Commander-in-Chief.

With due apology to the Statesman, the writer wishes to add a few names to the above who were also the first products of the I.M A. and who are now prominent in Pakistan. Firstly Umrao Bahadur (a) Mohd Umrao Khan, a beloved friend of the writer when they were contemporaries as young Jemadars at the Kitchener College and then at the Academy and went to the same battalion 2nd. 1st. Punjab Regiment after gaining their Commissions. He is now a Major General and the last he heard of him, he was the Chief Administrator of East Pakistan. The other, Mohd Musa, who the writer heard is likely to be the next Commander-in-Chief for the Pakistan Army. Pakistan could not have made a better choice. Last, but not least, Mohd Habibulla Khaltak (a) M. H. Khan, the last the writer saw in the papers that he was representing his country in S.E.A.T $\mathbf{S O}$. Conference as a Lieut $s$ General. To all officers mentioned above the author of this book wishes to say that the Academy days of affection, mutual love and cooperation are still vividly remembered by him. 


\section{CHAPTER 4}

POST GRADUATE TRAINING

\section{A Year with the British Unit}

Like all others officers of the Indian Army for generations, officers on first Commission had to do a year with the British unit as Post Graduate Training. So the author was posted to the 2nd. Battalion, The King's Own Yorkshire Light Infantry at Agra. He went there with one of his best friends at the Academy, Bhagwati Singh, one of those mentioned above. A very fine battalion indeed. He did his best to put up a good show both off or on parade, and also tried to learn as much as possible from them. There he was given a platoon to command, but it must be admitted that most of the work in the platoons were done by Platoon Sergeants who knew much more than any young Subaltern. His platoon Sergeant was a small man like himself, by the name of Dooly. An energetic, efficient, witty and also humourous person at times. With the help of his Platoon Sergeant he got on very well indeed with his platoon even though they were of different colour. Having been through the rankss he knew all their troubles and needs and tried to help them to the best of his ability. He took part in nearly all games and athletics in the unit or when competing with others. When he was about to finish his attachment many men of his platoon came and asked him if he could not remain with them in the battalion. He had not the slightest doubt, that it was a sincere expression of their wishes. The Commanding Officer of this unit Lt. Col. T . B . Butt always introduced him to any new comer as "A Pocket Guardsman," after his name. He never learned unto this day if the C.O. meant a small man but as smart as the Guards, or any other meaning. He really enjoyed his attachment with them and also learned many things which were useful in his future career.

\section{2nd. Battalion, 1st. Punjab Regiment}

As B urma was still a part of India when S. Dun gained his commission, he and his contemporaries could only be posted to Indian units which were earmarked for Indianization. So he applied to the 2/1 Punjab Regt. where his friend, Henson, already was. As they were the very first batch, there was little or no difficulty in getting their choice. His battalion was at that time stationed at RAZMAK on the North-iNest Frontier of India. Not many months later they were in the thick of the fighting against the followers of the Faqie Ipi. He had some experience with the Burma Rebellion in 1930-32 but, compared with this, the Burma Rebellion was child's play. The Pathan tribesmen were much better armed and had much more experience in fighting against the regular troops. Moreover they were well known for their marksmanship and tenacity in fighting. It was indeed an excellent training-ground for young subalterns like him. Although he and his men did not get any fighting worth its name, yet they did meet with opposition on many occasions in going up to pickets. In this type of warfare everything was laid down as a drill. Anyone taking it lightly and ignoring this drill was bound to be caught in the neck sooner or later. There are drills for going up to a picket, crossing nullahs, patrolling etc. When crossing a nullah, there must be a covering party 
until the first wave got securely on the top of the next hill which again acted as a covering party for the rear wave or party. There had been so many regrettable incidents in the past for those who were caught in the nullahs. Varying routes and time in patrolling was also important. The old Pathan was always watching from between the rocks and caves ready to make good use of any opportunity that may come to hims Apart from gaining good experience and training, S. Dun had done nothing much worthy of note in this particular operation. There were a few units which had the opportunity of putting up a good show and also suffered some casualties. A subaltern and also a Pathan in his own unit won the immediate award of M.C. in this operation.

There was one most amusing incident and not a little exciting for $\mathrm{S}$. Dun during his service on the N.W. Frontier. A few months before the trouble started, the Pathan Subaltern Lt. Adam Khan came to know a well-to-do tribesman who lived not far from Razmak. The Subaltern was invited to dinner one day; he in turn invited some of his mates to go with him. On arrival Dun found their host was no other person than the man he had had a quarrel with at Bannu on his way to join his battalion a few months before. It so happened that this old Pathan had some buses plying between Bannu and Razmak on hire. The day he arrived at Bannu all other buses were on strike except the buses of this old boy. Naturally his fares for the trip went sky-rocketting. Dun refused to pay his exhorbitant fare and asked his luggage to be unloaded. The Pathan was furious and his attitude and behaviour all showed that he was abusing and threatening in his own lingo. Dun retaliated in his own. The old boy had a rifle and a bandolier full of rounds an ornament the tribesmen valued more than gold. Looking at the way his hands caressingly moved up and down, there was no doubt that in his mind was a desire to plug his adversary full of lead if he could. Having heard so much about them and their ferocity, Dun had to follow suit by caressing his own .38 pistol lest he got a few quick ones in his chest. However the incident ended quite amicably. It was not known if he remembered his guest and the incident; if he did he must be classified as a perfect gentleman. He was a perfect host and the feast he laid on was excellent. It consisted of pilao, khabab, chapatis and big chunks of roasted dumba. It was such a change from the monotonous menu of the Officers' Mess. Dun did enjoy the feast, but inwardly he felt a bit uneasy for the return journey. Because he heard that these tribesmen can be most hospitable even to their enemies under their roof and protection but, once out of their domain, they are liable to remember their feuds and grievances. However he remained a perfect gentleman.

Multan

From Razmak the battalion moved to Multan, one of the hottest stations in India. When war broke out in 1939 the battalion was assigned for internal security duties, guarding railways and important bridges from possible sabotage. There was one more amusing incident during one of these moves. Dun and another Senior B ritish Officer Major P. Sainter M SC. were sitting in a carriage, stripped to the waist owing to the midday heat. A suspicious Police Inspector approached him and began to question him about his destination and where he came from etc., to which Dun had to give rather ambiguous replies for security reasonss The Police Officer became more suspicious. He was evidently detailed to look out for fifth columnists. Had the B ritish Officer not been there who told the Policeman that he was an officer in the Punjab Regiment, the incident could have turned out to be quite an embarrassing one. The Police Officer would have never believed him that he was an officer from the Punjab Regiment. If it had been a Gurkha Regiment it would be different. The Police Officer however was quite satisfied 
when he heard from Major Sainter. He politely saluted and apologised and went away. As there is little difference in appearance between the Chineses Japanese and the Karens the Police Officer was quite justified in being suspicious.

\section{Burma Military Police}

In the early days of the war he was seconded to the B.M.P. for which he had been trying ever since he was commissioned. It so happened that his battalion was then under the Northern Command, commanded by General Coleridge, a brother of Colonel Coleridge who was one of Smith's C.O.'s in the 2/20th Burma Rifles and who knew him wells There was no doubt that the Colonel had passed on all the news about Smith now Dun to his brother the General. Coincidentally during that period Dun also had a cousin in the Burma Legislative Council who kept on putting pressure on the Burma Government for his return to Burmas now that Burma had been separated from India for over two years. There was no doubt that it was the string pulling from both sides that brought him back to Burma. The General sent him a very nice letter after he got back to Burma.

The life with the B.M.P. was quite a rosy one. There was little routine and office work, but plenty of touring in districts where there were B.M.P. outposts. The allowance alone was nearly as much as a subaltern's basic pay. It was the first time that Dun could afford to live with his family with some means and comfort, and for nearly two years it was really nice and peacefuls since Burma was still untouched by the war. Rangoon had the first taste of war on the 23rd. of December 1941, when two fairly big formations of bombers came over and unloaded their bombs on the town, causing a good deal of damage to lives and properties. The same evening the Japanese promised on their radio that they would bring a $X^{\prime}$ mas present in the same way on X'mas day. They kept their promise and did another bombing on the 25th. More damage to property but less loss of livess After this there were incessant scare raidss specially at nights, causing Dun to evacuate his family into the countrys never to see them again until after the war. 


\title{
CHAPTER 5
}

\author{
EVACUATION OF RANGOON
}

On the 28th of February 1942, it became evident that Rangoon would be given up in spite of repeated announcements made on the radio that it would be held at all cost. On that day the two battalions of B.M.P. in Rangoon were ordered to evacuate northward in order to avoid congestion on the road as the Army in Burma was rapidly pushed back by the Japanese, from the Eastern Frontier. By that time Rangoon was almost a ghost town, as nearly all its inhabitants had left except those who were forced to remains either by circumstance or by orders to stay put. Indigenous races went away to their villages and districts while the Indians and Chinese were heading north by every means of transport and many hundreds and thousands on foot.

As the B.M.P. had not enough transport, only the baggage was carried on wheels and the men marched to Tharrawaddy, except for the sick and the weak who had to be ferried as necessity arose. On arrivals howevers Dun and five-hundred men were ordered back to Rangoon to restore law and order and get rid of bad hats who were now having a glorious time in looting and burning up various quarters in Rangoon. Meanwhile, the Army in Burma was withdrawing fast. On the 7th of March 1942 complete evacuation was ordered. This time enough transport was provided for the B.M.P.s as they had now come under the Army. The convoy left at about 12:00 noon and, to avoid congestion on the Prome Road, it took Insein Hlawga Road, which joins the Prome Road at Taukkyan. Dun was leading his convoy in his small car. Everything went smoothly until he got to Taukkyan junction. There he was confronted by a Red-Cap, not a provost but a Senior Officer, who was turning all the vehicles round, because there had been a road-block by the Japanese since early morning. Several attempts were made to break it but the Japanese held on grimly until the next morning, when it was finally broken after some fierce fighting. During the evening Dun received a warning order from his C.O. Major $\mathrm{H}$. Chappel, that he must be prepared to go in and help to break the road-block if necessary. In response, Dun gave out his warning orders to his subadars and jemadars and waited for the final order, which fortunately never came. He had under him then about two companies, plus Gurkhas and Kumaonis and about an equal number of Karenss and some Burmas. Although the materials were goods they were pathetically untrained for modern warfare. They spent all their lives in garrison duties. He often wondered what sort of a show he would be able to put up if it were necessary for him to attack the Japanese with those troops. Later in the war these same troops did quite creditably after some training in India.

That road-block was cleared at some cost to our side in men and materiel. The next morning when convoys were allowed to proceed, there were Japanese corpses still lying about and one of our tanks was lying tilted over a mine. Dun and his troops got into Tharrawaddy without any more incident after that. Now that the B.M.P. came under the Army, a liaison officer was needed at the Divisional Headquarters. The same evening Dun was sent for by his C.O. who was now Colonel Martin who had been given command over both 1st and 2nd B.M.P. Battalions which 
were now amalgamated. Dun represented both the $B$ urma Military Police and the B urma Frontier Force battalions at Div. HQ. He went and reported himself as ordered, and made some friends there who wese mostly younger than himself and were all Captains. No one seemed to take much notice of him and some might even be suspicious of him, as the activities of the B.I.A. (B urma Independence Army) and their accomplices were well manifested by now. He felt quite a stranger until the following morning when he met the Divisional Commander Major-General D. T . Cowan, who had been his Company Commander at the Academys Both of them were equally surprised to meet unexpectedly. After some personal questions and answers and handshakes the General asked him if he had evacuated his family northward. He was very disappointed to hear the reply in the negative. As the Japanese advance and our withdrawal were so rapid, there was nothing else that could be done but to hope for the best. However as things turned out it was definitely the best for his family. Had he tried to evacuate them northward they could have easily got stranded away from home and relations. He would not be able to be with them and render any help as he was now actively engaged in the war. There were many deaths and human suffering throughout the way to India from diseases and exposure among the evacuees, which made him rather grateful for having sent his wife and children to his village among kith and kin.

The General's parting words of that particular meeting were, "Are you still a lieutenant?" "Put on three pips.s" Dun did put on three pips the next morning and he could see many sly glances at his shoulders from his contemporaries on the staff. One in fact did ask him if he had not promoted himself. Dun said No, of courses and explained. Actually he was already overdue for a substantive Captain by virtue of the number of years of his commission service and was waiting for the Gazette to come out, but it never caught up with him.

Early Desertion of Karens in B.M.P.

On the way from Rangoon to Tharrawaddy the Karens began to desert, specially those who had to pass and leave their villages behind which were within view from the main road. Moreover, there were already rumours of clashes between the Burmans and the Karens in various places. The men were naturally anxious about their homes and families. Dun felt very bad over this, because the Karen deserters were letting down their Karen people and him in particular as he was the only Karen officer in the unit. Unable to bear his disappointment any longer he confided to Major Jones, a senior police officer who joined the B.M.P. as the second in command of the battalions He said, "Don't worry about it Dun, sit is alright, they have gone to protect their homes and families.s" On hearing his views on the subject Dun felt much better. A very understanding officer indeed.s Such understanding British officers were pathetically few, even though they had ruled Burma for nearly a hundred years. It was revealed at the end of the war that these very men from the B.M.P. had saved many lives and villages of the Karens from loot and plunder and in some cases from utter destruction by the B.I.A's and local bad hats, who flocked under the B.I.A. banner in large numbers. There were many instances to support the corsectness of this officer's view as stated above, but the following two examples should be sufficient. Firstly at Dun's own village as law and order disappeared, these bad hats roamed about the village in a challenging manner. Luckily there were rumours among the Burmese of neighbouring villages that Dun had left a good deal of arms and ammunition for the defence of his village. Coincidentally, a Chinese shop-keeper of the village brought some heavy boxes of merchandise from Rangoon back to the village just before all means of communication stopped. When questioned by these unreliable characters, the Chineses astute as he was, replied that he didn't know what was inside but they 
had been sent by Dun from Rangoon. His only motive in this reply was to save his goods by putting some fear in the bad hats, who either knew or had heard of him, of possible retaliation and revenge if they touched Dun's property, having no idea what effect it would have to his and the Karens' advantage. In actual fact there was only one rifle that had been brought by one of the deserters mentioned above. To deceive their adversaries or the B.I.A. followers, different persons had to carry the same rifle in turn, sometimes with bayonet fixed and sometimes without bayonets in full view of their Burmese neighbours who were still carrying on petty trade in the village. There was no doubt of course that these Burmese petty traders passed the news to their Burmese undesirables. To imitate a Lewis gun, the Karens made a dummy guns covered it with a blanket and talked about it openly within the hearing of these traders. Of course all that was seen and heard got back to the Burmese bad hats. The ruse and the deception had its desired effect. The Burmese never dared to attack that village, in spite of many threats and rumours of imminent attacks by them.

The other example was a village some ten or fifteen miles away from the above. It was attacked by a few hundred Burmese bad hats, with assorted arms, but the majority were dahs (thick broadbladed knives) and spears. Of about equal number with the attackers were those who came in carts and kept at a distance waiting their chance to loot. In the village there were some five or six of the deserters mentioned above who were actually in transit to their respective villages. It was most fortunate for that village that the attack took place on that particular day. Had it been earlier or later it would have been completely overrun and plundered with loss of lives, women and children included. In this case the five or six riflemen held the attackers for the whole day. By the time the battle was joined a few self-appointed (Bohs) or officers had been picked and knocked out. This had some deterring effect, but the attackers still surged forward slowly, with shouts of encouragement and pressure from behind from those who had not yet felt the real sting of resistance from the village; and the attackers no doubt were quite sure of themselves, with the number of men behind them and the amount of fire coming from the village in its defences But when they were about 200 yards or so from the village fence, the defenders had to increase their rate of fire which caused more damage to the bad hats. The Riflemen ruddy well knew that they had only a limited number of rounds and their rifles would be no more darn use than a stick without rounds. Hence they were conserving their rounds as circumstances demanded. Thanks to the training in fire control given by the B ritish to their defence forces, as more were knocked out or wounded, the Burmese bad hats were now forced to take cover behind the low bunds of paddy fields which surround the village. It was then ten or eleven in the morning of one of the few hottest months in Burma, "April." From now on, the scorching sun became the best ally of the defenders. The attackers were slowly worn out by the burning heat and thirst, and were entirely at the mercy of the defenders, once they left their covers. In this way many were shot and only when darkness came were they able to withdraw, taking with them the tale of woe and slaughter by those they went out to slaughter.

\section{To the Ava Bridge}

The Burma Army or the Army in Burma withdrew in two columns, Bur. Div. or Burma Division along the Rangoon-Mandalay axis, and 17 Division along the Prome Road axis. Several important episodes took place between Thurrawaddy and Prome, such as the battle of Paungde, when part of our Armour got involved with some success. The other was the battle of Shwedaung, where for the first time the Burmese Independence Army took part in force, in support of the Japanese Task Force. Casualties were heavy on both sides in this battle. By this time Dun 
was a full fledged Divisional Staff Officer with a roving commission doing various jobs as necessity arose, such as interrogating, interpreting, and sifting intelligence from captured documents and locals etc. With his knowledge of the country and people, he sometimes was sent out to help units which went out on independent missions. On one of these missions, he saved three innocent livess $\mathrm{He}$ was then attached to a Sikh Battalion which was to march across country by the foothills of Pegu Yoma, in order to protect the right flank of the main Division which was withdrawing along the main road Allanmyo-Taungdwingyi. During the day a patrol brought in a man who was found sitting on a tree with his cross bow and arrows. He was evidently waiting for game at one of their feeding places. It was customary for barking deer, sambhurs and the like to feed at the same spot, especially on ripe fruit which dropped from the trees, and they go on feeding at these places until the season is over. This man was sitting up for one of these animals when he was found by the patrol. He was accused of being a spy, and with his deadly looking weapon and because some Burmese had already committed atrocities against our troops, he would certainly have been bumped off had Dun not been there to save him. After questioning both the patrol and the man, and having himself acted in the same manner and with the same weapon in his boyhood dayss he was quite certain that the man was only an ignorant and innocent villager who hardly knew that there was a war ons He actually supplied the very information which the patrol was trying to find out. The information that was needed then was whether the Japanese and the B.I.A.'s were in the vicinity and any news of their coming in that direction. He was kept with the unit and brought along some distance and allowed to go via a different route. It might have been an anxiety for his peoples and an experience for him to tell about when he got home. The battalion marched across country throughout the night, and just about dawn two locals were brought in by point section, with the same charges. These two men were evidently early birds for wood-cutting, each carrying a dahma, a Burmese wood-cutting dah which is heavy and deadly looking, not unlike an executioner's weapon. Investigation showed that they were merely innocent villagers who had no idea about troop movements; hence they came down the same track which the troops were going up. They were out to collect and cut materials for their huts for the coming rainy season. Once again two lives were saved. With the prevalence of traitors and with these men also being in possession of such deadly looking weapons, one could hardly have blamed the troops if they had taken drastic action on such occasions.

\section{At Taungdwingyi}

Once again 17 Div. dug in here with some rumours about fighting it out with the enemy. Whilst holding this position there was one amusing incident. One morning about ten or eleven o'clock, three Japanese bombers came over and dropped their loads as they pleased. However, when they went over an A.A. position, the guns opened up sending one plane blazing which fell in our front line. Everyone was so pleased with it that all clapped for joy. Not very long after, a bigger formation came over and dropped more bombss causing us to dive into our trenches and remain there for quite a considerable length of time. This incident often reminded Dun of the remarks of one of his friends who said that every time the bombers were over him the slit trench appeared to him as wide and open as the Prome Road and that he prayed more than ten times before the bomb touched the ground. This remark often caused him to have a quiet laugh, in that, how identical his feelings were with his friend, although he was not brave enough to admit it like his friend.

The hope of fighting it out there rose higher, when there were rumours about some Chinese troops which would be arriving soon to join in the defence. But they took so long to come that such hopes gradually faded away. Eventually a small 
number did arrive but they were ill equipped and clothed and could not have been much help in stemming the tide of the Japanese advance. One night a Japanese column broke through the front line between Magwe, and Taungdwingyi. This forced the 17 Divs to withdraw further north. This was done across country on cart tracks and part of it on railway tracks from which the rails had been removed. Meanwhile the town of Yenangyaung was taken by the Japanese, but was recaptured with the help of the Chinese army, and many prisoners from our side were rescued. The town was eventually given up to the Japanese, and the withdrawal continued. When $17 \mathrm{Div}$. reached Meiktila, it was in a blaze and therefore the Div. withdrew right through to Mahlaing. From thence the Div. withdrew to Kyaukse which was also bombed and burnt out. There were some gruesome sights of dead men and animals by the road side but everyone passed by without taking much notice of them. The night before the Div. withdrew one of the Brigades did a magnificent piece of work in an ambush, catching the Japanese by surprise and causing heavy casualties to the enemy. 


\title{
CHAPTER 6
}

\author{
WITHDRAWAL FROM SAGAING, KALEWAs TO IMPHAL
}

From Kyaukse the 17 Div. went across the Irrawaddy over the Ava bridge and took up position at Sagaing. The Chinese cooperated in the defence of the town, but there was no attack from the Japanese. Mandalay was smouldering in smoke when Dun himself drove past. A lone Phongyi lay dead by the side of the road, presumably a casualty of the Japanese air attack. The Division remained at Sagaing for about two days while streams of troops from various units and also stragglers were continuously crossing. When everything was across including the Chinese, the bridge was blown up and it went down with a tremendous crash into the Irrawaddy. It really made us feel then that Burma was lost and the thought of getting to India entered our heads for the first time.

From here the Div. went right through Shwebo to Ye-U and thence to Pyingaing. It was here when General Cowan once again detailed Dun to accompany the commandos consisting of British and Gurkhas, about two Companies, plus. This Commando unit was to head off the Japanese coming up the Chindwin and to allow the main Div. to cross the same river unmolested at Shwegyin. Their first task, which was to deny the enemy to pass a big village by the name of Maukkadaw, was accomplished without incident. The same evening the Commandos were ordered to proceed to their second tasks which was a village further north by the name of Ma-u-in; it was learnt from the agents sent out by Dun that the evening's advance party had come up to a village only three miles south of them. Howevers the move was carried out according to plan. The objective was about twenty miles north, and the going was to be cross-country. The Commandos marched for the best part of the night with little progress, owing to bad light and rough country. Fortunately the guide happened to be an efficient and reliable one who knew the area well. By the morning the troops were still in the thick jungle and only about halfway to the objective. The column rested for food and some for tea and left again at about ten o'clock. The going was still slow and rough. By about 2:00 p.m. they got into more open country and the speed improved considerably, but the heavy wireless sets which had to be carried by men were still holding back the pace. About 4:00 p.m. they came to the fringe of the jungle where a cluster of huts could be seen, with no visible signs of life. The column halted but ready for action while Dun, one B ritish Corporal and the guide went forward to investigate. There was not a soul in the village, although there were signs of recent occupation. They could not have gone out in their fields and taungyas because there was nobody in the paddy fields which were nearby, and in any case, it was long after paddy harvesting season. Moreover it was about time for villagers to be returning to their village from their routine work.

Following a footpath towards the village that was the objective for two hundred yards or sos a clue to the mystery of the dead village was found. There were unmistakable signs of Japanese boot-prints, and the enemy appeared to be in considerable strength. The party came back with the information thus gained, on which there was a short conference, and plans were made for possible action by the commander. The column then cautiously moved towards the village. It was 
dusk when the column arrived near the village and halted under cover of some scrubs and trees. The investigating party again went forward for more information. The party approached the village away from the expected entrance and the guide was sent in to fetch the headman of the villagen which he did successfully and discreetly, right under the nose of the enemy. A well-trained spy could not have done any better. The headman came but appeared to be very excitedn and worried. On arrival and with no hesitation, he said: "Thakin (Sir), don't come into the villagen please get out quicklyn the village is full of Japanese." Having calmed him down a little, a few questions were put to him for more information of military value. When questioned as to how many Japanese were theren he could only say "Amyagyi--Amyagyi" or "Many--Many." When asked to say in numbersn once again he would excitedly sayn "Thakin, many--many and full at village" and all the time he was looking over his shoulders, which action left no doubt as to the presence of the enemy in his village. He said they might even be looking for him at that moment and also said: "Please get out quickly from here Sir, please, they will get you otherwise. rh He was really worried and excited and the only way to get any information of value was to put to him definite questions. So the following questions were put to himn

"Are they about five hundred?"

"Oh much more, much more, Thakin (Sir)."

"Are they about one thousand?"

"No a little less I think."

"Are they about seven or eight hundred?"

"Er, I think so."

"When did they arrive?"

"About two hours ago."

"What are they doing now?"

"Some are cooking rice, some resting and a few seem to be keeping watch."

With such information gained, the party returned and reported to the Commander. Meanwhile sounds of motor-boats could be heard coming up the river from the rear of the column, and an officer from the party went down to investigate and saw more enemy disembarking behind the column. Dun had a vague idea of this of ficer mentioned heren who could easily have been B rigadier Calvert or the Mad Mike of Wingate fame. He was not sure who it was of course. The Commander on hearing these two reports decided to by-pass them, rather than to attack. It was almost pitch dark by then. It was not easy for a column of two fifty or so to keep in touch, specially across a country without any defined path. Dun was with the Commander at the head of the column. Having marched for an hour or so, the column halted to allow the rear to close up. But it never turned up; only then was it realized, more than half of the column, all Gurkhas plus some Britishersn had been lost and most likely had taken a different route. The Commander waited and waited until it was certain that they would not turn up. There were only about fifty men or so remaining with the Commander who now decided to move on. About two in the morning the Commander again halted in a nullah bed hoping that the lost column might still turn upn but it was all in vain. When morning came there were still no signs of them. Moving on a bit further the trail of the lost column was found not very far from where the Commander had waited. Having had only one light meal of bullybeef and some biscuits the previous day and having no time to refill their water bottlesn they all were beginning to feel 
the need of both food and water in varying degrees. All water bottles had been drained dry and being in the hottest month of the year all nullahs were as dry as bones. By thens eleven o'clocks the heat had become quite unbearable since whatever moisture that might have been in their body had been sweated out. By twelve noon some men began to drop out, causing frequent halts. It was then thought necessary to send out a search party for water. Dun and a few men went miles around as it seemed to him then, but found not a drop of water, and with great difficulty the party came back to the spot where the rest halted. By this time Dun himself was suffering from acute thirst and felt so hot within and without that he thought he would be knocked out with heat stroke and exposure at any minute. In the hope of finding water, at least five most likely spots had been dug with their bare hands in the sandy bed of the nullah to the depth of four or five feet but no water was found, except wet sands Everyone felt so hot and worn-out by that time that all stripped to the minimum and a few stark naked. The feeling of wet sand gave Dun a somewhat comfortable feeling which also gave him an idea to lie covered up in it. Having done so the effect was almost immediate and he therefore asked others to do likewise, and there they lay covered with wet sand and resteds caring nothings Japs or no Japs, killed or captured. By this time there was only one officer with him, a young Captain by the name of Samuel whom he called Sam for short, a tough, young Commando. But his enemys the thirst, proved to be more than even the Japaneses There were also about ten to fifteen B ritish boys, all Commandos, and a few were from K.O.Y.L.I.s the unit with which Dun did his attachment for a years and most of them knew him. The rest of the party, including the Commander himselfs went on through desperation while he was out looking for water. There was also one Burma Rifleman, a Chin who now became Dun's batman. About four in the evening, they all felt much better and refreshed, but their throats were still parched and dry. It was therefore decided to crawl out of their wet sand beds and try to make for their own lines once more. Having crossed a low hill they came to a paddy field where there was a buffalo wallowing with no waters but the surface was still wets The party instinctively dug it. At about two feet the water began to ooze out and about three was just enough muddy water to fill a mess tin in about five minutes. The water as would be expected, smelled of a buffalo. They however tried to filter it with one of their greasy handkerchiefs $\$$ and sipped it in turn to set their throats in the first few rounds. Even under such circumstances the discipline was excellents no one took more than his shares This proceeding went on for nearly an hour, by which time all felt much better and stronger even though the water was muddy and smelly. It was indeed a real wonder that no one contracted such diseases as cholera and typhoid etc. Once again they raised themselves to regain their lines. The thirst having receded their thoughts now turned to food. Luckily it was the season when new leaves and shoots begin to sprout in Burma. Knowing which is which Dun just plucked and ate them as he went along and also asked others to do the same. It must be a funny spectacle in normal time to see a bunch of men with branches and shoots in their hands and munching them as they wobbled along. The shoots were particularly nice under those circumstances as they contained some agreeable juice. The leaves were somewhat sours but were filling all the same. Having crossed a few more low hills on the way, the party ran into a crystal clear running stream, where they not only drank their fill, but wallowed in it for the remaining light, and rested there. Night came, and they were almost fighting fit, except half of the men had already abandoned their weapons and ammunition before they struck water. They could not be blamed as the writer himself felt like doing the same when tortured by that thirst. He even threw away everything including his pipe and a tin of three nuns tobacco, one of the few things that he loves most. It was only the pride of a professional soldier that caused him to retain his weapon 
and equipment and the dress he was supposed to wear as an officer. A tin of three nuns of four ounces seemed to weigh him down like a sack of rices The pipe from which he never seems to be divorced in normal time, he lost affection for and even sucking it empty appeared to him to be a burdens and it was the last thing that was thrown away. Had he gone in this direction when he was looking for waters our boys would never have been reduced to such a state. Why this stream was not marked on the map was indeed a mystery toos because it was at least six feet wide and a foot or two feet deep and evidently originated from a spring and thus must be perennial. By this time, it was already two days since they had been cut off by the Japaneses They pushed on towards their lines at first light and soon crossed the track which their Division had taken two days before. They had to cross many hills that day, as they took the most unlikely route that would possibly be used by the enemy. Each time they were nearing the tops a hope was raised in their hearts of looking down into the Chindwin rivers but each time they were only to be confronted with another great hill, with a deep valley between. By dusk they finally came to the Chindwin river, but there was no means of crossing it, except to swim across. The Chindwin is fairly swift and broad, so only a good swimmer would be able to swim across unaided. Luckily there was a raft of small bambooss which was again made into smaller raftss with the help of which the men were instructed to swim across, in parties of three or four. At the end Dun was left with four non-swimmers with all bamboos used up. It was really a problem for him then. He could have got across on his own steams even though it may mean casting away his equipment, but what about the non-swimmers who would never get across. Fortunately for them, he found a dug-out which at first looked like a half submerged log. It was damaged but still floated. They tried to bail the water out, but the water got in quicker than they could bail. So he turned it over and tried it as a raft which seemed buoyant enough to be used by just hanging on to it. The four non-swimmers were thoroughly instructed and also showed how to use it. The party got across alright, but not without mishap. Firstly Dun joined his boots by the laces and slung them across his neck to give him more freedom in swimming. As soon as he got out of his depth the boots were carried off by the current, thus he was now minus his boots. When the party got to the midstreams one of those who went ahead on one of the bamboo rafts cried out for help! On hearing this the non-swimmers got so excited that they jumped into the dug-out instead of just hanging on, as was instructed. The result was Dun had to swallow a bellyful of water as he was caught just as he was pushing and kicking with all his might. Naturally there came out from Dun's mouth all the juicy words of Tommy's language which he had picked up from them whilst doing his attachment with the British unit. The row made by that little party in crossing that river sounded then quite comparable with a B rigade crossings Luckily there were evacuees all round, and no ones including the Japaneses seemed to take any notice. Finally, all got across and rested there and then on the bank. When morning came and it was light enough, the only officer who was still with him was found to be minus everything; clothing, arms, equipment and all. Coincidentally someone had hung a pair of trousers by the nearby tree, no doubt with the intention of drying them, and the owner still sleeping through fatigue. No one objected when Dun hinted to the officer to put them on, having in mind that it would be better for other ranks to be found without trousers, than an officer. Sure enough a young private was soon looking for his trousers with only a shirt on. From thence the party pushed on to Kalewa at the top of the hill they had to climb from the bank. The distance was only about two miles but walking those two miles barefooted was the hardest battle Dun had ever experienced throughout that Japanese war. A footpath with gravel, even thorns at times and across country was something for the feet that had been softened by being continually in boots or shoes 
for yearss It was almost torture to take a step forward over those sharp stones and gravel. However the distance was made, but with much pain and tears as one might say. On approaching Kalewa, Dun stopped the party and, having instructed them to watch his progress and clear signal, went on ahead with his batmans the Chin Rifleman. Just before he entered the town he picked up a pair of socks and boots lying not far from each other. Although they were torn and worn they fitted him quite nicely and indeed they were God sent gifts. There were many evacuees in and around Kalewa ands having ascertained from them the presence or otherwise of the enemys a clear signal was given to the partys All got into Kalewa safely, but three days after their main force had passed it. In the town, on roads and in deserted houses there were some bullybeef tins, biscuit tins and other provisions strewn about the places some partially used and some wholes As the place was clear of the enemy, the first thought was to have a bellyful of food before continuing the long march. Dun picked up some tins of bully and some packets of biscuits and set about with his batmans amongst the evacuees for a square meal, and the rest of the party followed suit on their arrival. The meal was excellent, specially when washed down with some hot tea, which he managed to get from an Indian petty-shop keeper. He was really surprised to see this Indian still running his small shop under such circumstances. He bought a tin of milks some tea leaves and sugar from the mans to whom he was really grateful. It must be sheer greed to make as much money as he could from the refugees and then make off to India at the last minute. Although his intention might be suchs his action turned out to be most chivalrous to such needy persons, like Dun and no doubt many other evacueess

Not very long after they got into Kalewas but not before they had eaten somethings it was learnt from some evacuees that a party of Japanese had been seen approaching the towns So the party had to leave hurriedly, looking back occasionally to see if the enemy were following. The road was packed with evacuees\$ some on the move, some restings some cookings while a few lay dead and rotting by the roadsides A woman carrying an infant ran after him and begged for some milks saying that her child was dying of hunger having had no milk for several days. It was a pathetic sight indeed, and therefore Dun gave her the half-full tin of milk which he intended to save for the journey. This incident of ten set him thinking and as to what made this woman to pick on hims and how did she know that he would have some milk and would also part with it, since all had reached the stage when everyone was for himself. He also wondered if the mother and child did get through to India at all. Further along the road he came across more pathetic scenes. A woman lay dead while her infant child was still living, and yet another where a child was stone deads but seemed to be still sucking its feeding bottle. Further along the road still he heard groans of someone in a deserted truck definitely in great pain. Curiosity brought him to the scenes and there he found a young mother-to-bes with another attending, to bring in yet a new life into the world in the midst of such deaths and human sufferings. They rolled on steadily together with the refugees and spent the night just beyond the road junction Kalewa-Kalemyo. There was still no sign of our troops nor of the Japanese. On the morning of the fourth day Dun came across some stragglers cooking some rice in a deserted field hut, and they were all Gurkhass Enquiry revealed that they were men of 7 th Divs Burma Rifles, which was raised from the majority of Burma Military Polices and one or two had been in his own battalion before they joined the Burma Rifles. As he was pretty well famished by thens he just joined them for a spot of rice and needed no invitation. Like good soldiers the men treated him obligingly and shared their food without a grudge. The Gurkhas also came under his wings and the whole party now swelled to about a platoons Some miles further up the road he met a platoon of his own BMP men who seemed to be 
still waiting for orders to withdraw. As the order seemed to be well overdue, according to thems they too came under his wing and were all marching up towards home. Later and further up the road they met a ferry-truck, evidently sent out to ferry stragglers to our lines. The whole party got to our lines the same evening, where Dun rejoined his Divisional Headquarters. The Div. Commander General Cowan was mighty glad to see him and said to hims "I know you will get through,s' patting him on the back. Thereafter until 17 Div. got into Imphal Dun remained more or less in the pocket of his General and rode in his jeep. So much so that some of his contemporaries called him, sarcastically of course, the General's blue-eyed boy. A few days later the retreating Burma Army reached Imphal after passing through 23 rd Indian Division which was now holding the frontier. Imphal also bore the scar of bombing and strafing when Dun got in.

The 17 Div. remained at Imphal, to be refitted and also act as a reserve to 23rd Div. in case of enemy pressure. There was also one embarrassing but more amusing incident at this stage. As stated in the pregoing paragraphs, General Cowan had been in the habit of sending Dun on any errand great or small since they met at the Indian Military Academy. On this occasion, after briefing him on the position of 17 Div., the General sent Dun out as a representative to attend the conference held at $23 \mathrm{rd}$ Div. The Commander of this was his opposite number at the Academy, Major-General Savoury who commanded "A" Coy . at the Academy when there were only two Coys. at that institution. Each General knew Dun as well as the other. When Dun arrived to report to the staff officer at HQ 23 Div. that he was the representative of $17 \mathrm{Div}$. to attend the usual morning conference of theirs the staff officer began rattling away in Hindustani, addressing him as Subadar Sabs Dun had no alternative but to reply to him in the same language and pretend to be a Subadar, until the General himself arrived for the conference and started greeting him: "Hullo Smith," etc. and continued their conversation as old acquaintances would. The staff officer must have felt a little awkward after this; on the other hand Dun had no ill feeling about it as it was not the first occasion that he was mistaken as such. Dun knew of course he had been mistaken for a Gurkha officers who was rarely if ever seen as a King's Commissioned Officer at that time. 


\section{CHAPTER 7 \\ STAFF COLLEGE QUETTA, REJOIN 17TH DIV S, \\ CHIEF LIAISON OFFICER IN BURMA \\ INTELLIGENCE CORPS}

One day General Cowan said to him: "Dun, now you better attend the Staff College $s$ " To which he replied: "Thank you very much Sir, but there is nothing much in this, sointing to his head. The General then said: "It is alright, damn it, take it in your stride $S^{\prime \prime}$

One day the Army Commanders General Slim came to see the Division at Imphal. After visiting the various units, all officers of the Div. HQ. were lined up to hear a pep talk from the Army Commander, after which all were introduced to him by the Div. Commander. When he came to Dun, the Div. Commander also put in a few words about his wish and recommendation for him to attend the Staff College. To which the Army Commander said, "Oh yes, I remember him," and turned to Dun and asked, "You jumped one inch above your head at the Academy didn't you?" He had to reply, "Yes Sir," though actually he had long forgotten the incident.

As previously stated, the front line had been taken over by another Division, so the 17 Div. could now reorganize and recuperate from the ordeals of its retreat from Burma. A small percentage of men and officers who could be spared were then given a month's leave. As Dun was to attend the Staff College he was naturally on the priority list. For his leave he headed straight to Calcutta and to the "Grand Hotel" which he knew well because he invariably stayed there whenever he went on leave to Burma from India in peacetime.

On this leave he went with a friend by the name of Bilgrami, a young Indian Captain who was one of his contemporaries on the Div. HQ. They rolled up at the Grand one evening, just in jungle outfit as one might say and only a pack each on their backs as their belongings. Everyone in the hotel seemed to be eyeing thems but instead of being ashamed of their condition, they felt rather proud of their experience. As soon as they got into their rooms the first thing they did was to have a long hot bath which they had not seen for the last five months. They really made themselves at home that evening, ordering their food and drinks in their rooms. One reason of course was they had no suitable clothing to appear in the lounge and dining rooms. It was really a treat to be between clean sheets and on a soft bed once more. The following morning they went round shops busy buying and ordering clothes to refit themselves with suitable clothing. Thereafter followed a real relaxation both for body and mind to make up for the hardships they had endured in the withdrawal. This relaxation no doubt gave the various germs contacted on the way a chance to develop and get the better of the system. As a result, Dun was laid up with high fever even before the end of his leave. It took him nearly a month to recover from this illness, just in time to attend the Staff College.

As has already been mentioned elsewhere in this book, Dun was anything but outstanding in any book-work. To work out problems out of books and manuals 
was beyond him, specially things that involved mathematics such as stores, tasks and ammunition etc. On the other hand, his twenty years of service through every rank from a recruit to a captain taught him a good deal practically. When other students referred to various handbooks and textbooks, he referred to his various experiences appropriate to each occasions For instances to work out personnel, stores and time required to construct a certain defensive position, his mind would automatically turn to a certain experience he had personally had at one time or anothers Thus his years of practical experience were in fact his handbook of reference with which he managed to keep above average throughout the courses About a month or so before the end of the course, students were asked or detailed to give lectures on various subjectss He was appropriately asked to talk on Burma together with one of the Directing Staff Officers of the College who had taken part in the first Burma Campaign. To avoid overlapping, it was decided that the Staff Officer would talk on Burma in general and Dun would confine his talk to the delta area where he liveds The Staff Officer's lecture came mostly out of the books written by various people on Burma. No doubt he had seen Burma only hurriedly and within the confines of the lines of withdrawal. It could not have been very interesting to the audience or studentss since everyone listened with long faces and bored lookss Dun did not hear much of the lecture as he was engrossed in his own lecture which he would have to deliver in a few minutess The first part of the lecture on Burma ended with no visible signs of enthusiasm and Dun noticed one or two boys in the back rows, where he nearly always chose to sit to avoid being asked questions about which more often than not he had no clue, and the boys mentioned above were almost fast asleeps When Dun got onto the platforms he went behind the desk as the instructors used to do. The desk was so high for him that he could hardly see over it. Having the sleepy audience before hims he seized this opportunity to open up his lecture with a humourous remark. It was the form for all instructors to begin their lectures with, "Gentlemen, stop me if you cannot hear me, etcs" He started likewise and also addeds "or else if you cannot see me," with emphasis. Whereupon a thunderous laughter broke out from the audience, which no doubt woke up the sleepy ones who also joined in the laughter which lasted several seconds. The success of his humourous remark was more than he expected. When silence reigned once more, he continued his lecture much encouraged and full of confidence. He talked about the topography, people and their characteristics, and who were likely to be loyal or otherwise, and local supplies etc. In fact he talked on all matters which he considered to be of military importance. Considering the various questions he was asked at the end and the pat on the back he got from the Commandant B rigadier Evans, it must have been of some interest to his listenerss

At the conclusion of the course, all students were interviewed individually by the Commandant, giving them their reports, recommendations, and also advice where necessary. Once again the report was more than he had expected and certainly he had no reason to complain about it. When asked by the Commandant what sort of staff job he would prefer to have, his reply was to be returned to his old unit the 2/20th Burma Rifles for regimental duties. As most officers' replies were this or that staff job, as they considered themselves to be most suiteds the Commandant was certainly not prepared for such a reply, and his countenance showed it; so Dun had to give his reasons for his request, and that was that his old unit was taking part in the first Wingate Expedition and that he wanted to be in that show with troops of his own kind. The Commandant seemed to have noted it down; but Dun was never sent there but back to 17 Div. as an intelligence officer in which capacity he served until Burma was reoccupieds He never knew unto this day, whether it was because he was considered not good enough for that show by the authorities concerned or else his old General wanted him back in his own Division. 
He was now back with the 17 Divn as a Major with the designation of Chief Liaison Officer of the Burma Intelligence Corps (BIC). With all forward Divisions there was a platoon of BIC men. Their main task was to help all forward formations with their knowledge of the country, language and the people, as the advance progressed into Burma propern They acted as interpreters, translated captured Burmese documents, sifted and collected intelligence from the locals or captured suspectsn In fact they were the eyes and ears of all foreign troopsn Being an intelligence Corps itnhad a very high proportion of of ficers and also of transport. There were nine of ficers including himself for the platoonn But it was later very much reduced as the Corps expanded to meet the demands of more formations that took part in the recapturing of Burman On his arrival, the Divn was on road construction duties from Imphal to Tiddim, the capital of the Chin hills, and thence down to the Chindwin at Kalemyon

When the road was through to Tiddim the Divn HQ moved up theren As their envisaged work would not be in full swing until they entered Burma proper, only a couple of men were attached to the most forward detachments which were watching strategical points as standing patrols. Instead of keeping the remainder idle at headquarters, Dun took turns in providing reccen and standing patrols in order to toughen his men and also train them in the art of patrollingn There were a few incidents, which were quite exciting as well as amusing to look back on now, whilst they were thus employed. One of these was at Kun-Yun, one of the highest peaks in the area, and there they were to establish a standing patrol and report by wireless any useful information and movement of the enemy that may be obtained by observation and patrolling. Information was received from the Chins that enemy patrols did come and gon but they never reached their position and under their observationn One evening about eight o'clock, Dun's attention was drawn by a sentry who saw hundreds of moving lights going out of the villagen The villagers were definitely using pine or thatch torches which flickered like fireflies from a distance and were rather fascinating to watch. It was evident that either the presence or approach of the enemy caused such an evacuation of the village by villagersn Thereupon Dun set about an ambush at what he considered was the most awkward place for the enemy to be caught, and the easiest for his party to get away after doing as much damage as possible to the enemyn From the village to where the ambush was laid would take the enemy at least three hours since they had to climb and climb and the foot-path would allow only a single file. Having put each man in position with all knowing exactly what to do, and having posted sentries, Dun and the rest of the men retired a few paces to the rear to relaxn Dun lay listening and heard the sentries change twice, which by that time meant it was on 12 midnight when he fell asleepn Having in mind all the time how to catch the enemy in the reentrant just below the position, he might have been half conscious when he suddenly awoke, and before he could collect all his wits he really thought that the battle was on and that his men were blazing away with all they had. When he was himself once more he found that it was but the snoring of his men who had fallen asleep like himself. By then it was past $2 \mathrm{a} . \mathrm{m}$. and being only about half-moon and no breeze, indeed it was a still night. There might have been at least three men lying snoring by him with varying intensity, and onnsuch a still night and under such suspense, the row was indeed alarmingn He went round waking and cursing everyone under his breath, when silence seemed to return once more. The two sentries who were ten yards or so away did not think that the snoring was particularly noisy. However, there were no signs of the enemy, and just as welln If the hearing of the enemy was as sharp as his, at that particular moment he thought that they could hear them from at least a hundred yards distancen The party remained more or less standing to till dawn. At first light a two-man patrol was sent out to make sure there was no enemy within the 
vicinityn On the patrol reporting all clear, a bigger patrol was sent out to the village to find out what the fire display was all about during the night. The patroln seeing the village more or less normal, went in and contacted a Burmese-speaking Chinn who informed the patrol that a strong force of the Japanese had visited a neighbouring village and was expected to come to theirs, hence the alarmn It was evidently the enemy's fighting patrol sent out as a feelern

About two months later there was another incident at a village called Sailunun, also in the Chin Hills. It was now March, and the enemy were definitely more activen The standing patrol under the name of Dun Force had been in this position for well over a monthn From this position two or sometimes three-men patrols were sent out almost daily towards the enemy lines to contact agents who were planted in various villages that were between our own lines and the enemy. There was also the Manipur river, which is fairly broad and swiftn between the lines. This river can only be crossed at the lowest level and at fords onlyn This patrol was under a subaltern and Dun only went out occasionally to see to the welfare of his men. But this time there was news of Japanese concentrations on other fronts, and also increasing activities across the Manipur River opposite the above patrol. Dun therefore went out one dayn taking with him mail and amenities for his menn but his prime motive for the visit was to boost the morale of his men. On his arrivaln the subaltern who was in charge of the patrol requested leave for some personal affairsn He was allowed to return and Dun stayed on. The same evening the patrol brought news from agents that there were about 1500 Japsn appearing to be concentrating on the other side of the river. The following morning another message was received from agents that the same party had crossed during the nightn Although he did not discredit the information receivedn he thought that the number of the enemy had been grossly exaggerated and reported back to headquarters to that effect. The same evening another message was received that the enemy was heading towards his positionn He once again made plans for an ambush and quick getawayn Having only fifteen menn he could not do much to stop them if the number reported had been accurate or even a near estimaten but he could inflict some casualties and delay them with some sort of opposition; above all to find out the strength of the enemy, which would be most useful for the Headquarters to known Night came, and it was a very bright night indeed. It cannot be remembered if it was just before or after full moonn but the moon was pretty full and brightn It was also cloudless and little or no wind, thus the bright still night evidently favoured the defendersn To avoid being surprised Dun divided his men into two groupsn within covering distance of each othern His orders were to allow the enemy to come up to a certain point (pointed on the ground) when the party concerned was to let loose hell on the enemy with all what they hadn and withdraw to a certain rendezvousn With his previous experience of men snoring and moreover with the patrol having been static in that position for quite a considerable length of timen Dun naturally surmised that the Japs had no doubt a pin point of their position from the local Chinsn which happened to be the case as proved by the following morning. Dun could not sleep a wink that nightn which he thought wasn't because of fear but too much excitement. But the reader cannot be far wrong to take it that it was because of fear, excitement, suspensen self-preservation and all combined. Because for any man or animal, however braven self preservation is always the first thoughtn From sundown onwardn everyone was keyed up and all eyes were glued on likely approachesn The fun came at about eleven o'clock that nightn Being some distance away from headquarters, the party kept a few chickens for their fresh meat supply which they bought from the local Chins. There was a rooster among these chickens, which Dun failed to cater for in his plan of defence and precautionn At that hour the rooster started to crown And what a crowing it was! He really thought and felt that he had never heard a 
rooster crow as loud as that one in all his life. They were then trying to keep dead silent and flattened themselves on the ground to avoid being seen or heard. The crowing of a domestic rooster could not possibly be mistaken for a wild ones In order to silence it once for alls Dun picked up a bamboo rod and cautiously approached the crowing cock. Although domesticated and tame, being bred and brought up in the Chin Hills, there is no doubt that he inherited all the wildness and wisdom of his jungle relations. Although consciously approached by his assassin, he was not to be beaten and was alert and full of wits. He was rising and ready to fly when Dun got within reach. Just as he was to fly off Dun tried to hit him across his neck but caught him by the tail. As a result there was a hell of a lot of commotion made by him and his wives which echoed several times round the Chin Hills, as it then seemed. There was nothing else to do but let them settle down. But their cackling or the ka-ka-ka-katauk seemed to go on for ever. Luckily the Japanese never made their appearance throughout the night, nor did they make any attempt to catch the defenders by surprise. Morning came, still there were no signs of the Japanese. Patrols were sent out in all directions from which the enemy was expected, but all came back with negative reports. Orders were given for cooking, and tea was the first thing that was made. The party was just about to relax and discredit the information received the previous day, when the cook who was taking tea up to No. 1 position ran back to tell the Major that the Japanese had arrived. On being challenged, the cook dropped his tea can and ran for his life. Evidently the enemy was trying to effect surprise by withholding his fire on the cook. Half-heartedly Dun ordered the party that was with him to stand to.

The N.C.O. in charge of the other position, on his own initiative, vacated his position and took up an alternative position soon after first light and just before the Japanese arrived. What made or moved him to do so will never be known, but one thing Dun knew about this N.C.O. was that he was a good soldier and a devoted Christian. They were hardly in position when the enemy made his appearance. One of the headmens who had been our staunch alliess was seen among the enemy. He appeared to be the guide of the partys as on arrival he was pointing to various positions; there was no means of knowing whether he did the stuff in our favour or against. Whichever it may have been, our men just emptied their magazines in accordance with given orders. They saw the headman and some Japanese bowled over, or maybe diving for cover, but all were flat on the ground while the men continued to pump their lead into it. The number of the enemy, including some localss was estimated at company strength. They had headed straight to the position and surrounded it buts on seeing that it was empty, they had seemed to be laughing it off, collecting in groups, most likely talking about the valour of the defenders. Just then our men opened upswith all they hads as previously mentioned. The enemy was so surprised that they had no time to retaliate, and the men withdrew without any accident. Ordinarily the Japanese were very quick to retaliate, even though blindly and just to frighten their enemy. By about eight a.m. all were at the rendezvous. As it was too close under the circumstances the patrol continued to withdraw for another two miles, to where the Commander considered the position for observation. The Japanese however lay low for the rest of the day giving us no clue as to their strength and intention. Since only about a company was encountered, only that number was reported back to headquarters, also with the claim that at least 20 had been killed or woundeds of course with quite a clear conscience.

Since the enemy made no movement that day it was most difficult to report to headquarters as to their strength and movements. But one thing was certains and that was that the enemy could only advance by one route and in single file only. 
So Dun and his men sat astride that track, at the most advantageous position if the enemy ventured forwards No message was sent that day, either to deny or confirm the strength of the enemy received the previous day. There were no means of finding this outs except to sit tight in that position and continue to observes Night came, and naturally an ambush was laid on for the enemys At about 12 midnight the enemy's two scouts, cautiously appeared on their hands and knees; no doubt they knew exactly where the defenders were from the few Chins who were allowed to return to their village. They had been instructed what to say and not to says but they certainly did not seem to remember it. Seeing the Japanese avalanching down on their old master the B ritishs who appeared then to be running away when and wherever the Japs appear, the old Chin naturally sided with the Japanese despite what Dun had told thems seeing that he had only a few men with hims If the Burmans who are the most enlightened of all the Burmese, or people of Burma, side with and change sides to whoever the winner will be, Dun had no thought of blaming those few Chins who had given his position aways Having lost surprise, Dun withdrew furthers ostensibly running away from them. A mile or so on the road of withdrawal the defenders came to two excellent positions for laying ambush. Having skipped the first, ambush was laid on the second, which was near the saddle and most advantageous for getaway. Having put all his men in position and given instructions, Dun and a few men including the cook, a Chittagonian by the name of Abduls withdrew to the saddle to act as a covering party, as well as headquarters. When sentries were detailed and posteds Dun and the cook also had to take parts as there were not enough men to do the job without them. The cook, relieving the Major on sentry duty, took up his position quite eagerly and confidently, and to all outside appearance he looked a veteran and a full-fledged rifleman, being no doubt quite proud of his elevated position from a cook to a combatant. Just as Dun was about to push off and rest it struck him to wonder whether the cook in fact could use the rifle and might not to too dangerous to the men in front. When asked by the Major if he had used or could use the weapon, the cook replied, "Bilkul hazur" "Yes Sir, perfectly,s" and added where he had used it before and how he could hit his target, etc. However, just to satisfy himself, the Major asked him for his rifle and checked his sights and safety catch which were in order. But when he opened the breech to see how many rounds he had loadeds it was empty. From this it was quite certain that he knew damn all about using the rifle. Howevers just to leave him his confidence the Major handed him his rifle, without any criticism, and told him not to fire without his orders, as by doing so he might give away the position and surprise to the enemy. The old Abdul seemed to be as pleased as punch and joker combined and left to keep watch. About 2 a.m. the Japs appeared, but not as cautiously as on the previous occasion. As the track would allow only single file they came up in that formation, closely packed; no doubt they were confident that the defenders had cleared outs after passing several positions where they had anticipated resistance. When the leading element was not more than fifty yards away and the reentrant was packed with thems the ambushing party opened up with all what they had, seeing definitely three men writhing on the track; there were no means of knowing what other casualties the enemy suffered. Within a few seconds two shells burst near the defenders. Fortunately they caused no damage. The mens having emptied their magazines of bren, rifles and stens, withdrew in accordance with the given order. As aforesaids the track allowed only a single file as the men were on the higher ground on or near the cutting, the Japanese could not bypass nor charge them. But they retaliated with fire as hard as they could. The astonishing thing was, although the enemy's fire seemed to be very intense, no bullets could be heard whizzing about as would be the case if directed on the position, so it is not known if the enemy let loose hell on earth in every direction to frighten 
away the ambushers by creating as much noise as they could. Dun was waiting for his men, who were now charging up the hill to the saddle. As each man came up, he was told to run down the hill to a certain rendezvous, and wait for him for further orders. Dun waited for the last man to come up, and his heart sank to the bottom when this boy of about twenty started groaning hard ten or twenty yards from him down hill. His first thought was that the boy had been hit seriously and that it would be beyond him to carry the wounded soldier down and up hill with the enemy on his heels. After a good deal of encouragement and effort, the man arrived and almost flopped down at the foot of his Commanders who naturally expected him to be covered with blood after all the enemy's fire, plus two big bangs which sounded as loud as a 25-pounder shell. It was such a relief when the Major saw no blood on his man, but there was no time to lose to question him as to where he was hit, so Dun just grabbed hold of his rifle in one hand and, the boy being taller than him, got under his armpit with the other shoulder and dragged or pulled him as fast and best he could down the track. On nearing the rendezvous, the boy regained his breath somewhat and was asked where he was hit, and his reply was far from expectation. He said: "I am not hit Sir, it is my weak heart.s"

That ambush certainly made the enemy more cautious in following. So the party relaxed their pace and continued to retire in quick time. On arriving at a big Chin village, which coincidentally happened to be the Major's batman's village, the batman was left there with instructions to collect more information and report back to headquarters as opportunity arose. Unfortunately, he never turned up to give more information about the enemy. It was quite possible that he was betrayed into the enemy's hands. His father had been a member of the Chin levies, which had been such a thorn in the Japanese flesh before their major push towards India. This batman's father had killed two Japanese with his own hands and celebrated his victory over the enemy with a big feast and dancing, in accordance with their custom; as the Major and his batman camped at the village on their way out to join the above standing patrol, Dun learnt from his batman that the feast cost his father several cows. It was the custom with them to celebrate any time they killed any dangerous animals such as bears, leopards, boars and tigers, which they consider to be the enemy of men. The more the danger the bigger the feast; no wonder that he spent several cows for two Japanese soldiers.

This particular action earned for four of the Dun Force mentions in dispatches. On reading other citations, the Commander of that party much regretted not recommending his men for higher awards, specially his Sergeant Major by the name of Freddie Gomes. He was in command of the particular party that remained, spraying the enemy with his tommy gun while allowing his men to get away. Being young and fit, he no doubt overtook and bounded past the man with a weak heart before he started groaning. If not, his Commander had not the slightest doubt that he would have had helped the weak-hearted man or at least stayed on with his Major, since he reported and only went on further on his Commander's orders. That little action, as learnt from later information, delayed a whole Japanese regiment for one whole day. Had that party not taken that particular action, the enemy would have gained one day and could have been quite a bad thorn on one of the flanks of the Division which Dun was in. The patrol arrived at Headquarters late in the evening quite exhausted. Chased by the enemy for the better part of the night, after which climbing a steep and very high hill nearly finished them. To compensate for all this Dun literally got a pat on the back from his General.

Not many days after this incident the Division was ordered to withdraw to Imphal. It was from this withdrawal and at the first camp that an unfortunate incident took place. It was not much of a camp, because there was only a narrow strip of flat ground and it was spread upon a fairly steep slope. Being an Intel- 
ligence Corps, Dun's men were kept among the administrative units, somewhere in the centre of the camp. No one knew the reason why. Firing starting at about nine or ten p.m. within the camp and literally in all directions, inwards, outwards and upwards, just completely foxed everyone, however clever, however brave. Nearly every weapon that was in the camp seemed to have been used. Mountain guns, brens, grenades including very light ones and tracers etc. Some officers got up and shouted at the top of their voices "Cease Fire,s" which only caused more fire and towards the direction where the order came. By this time nearly every man had heard more than once the tricks of the Japanese in imitating our own troops. Being unable to do anything under the circumstances, Dun's common sense told him to lie flat and still, and he shouted to his men to lie still. One bren gun started firing about two yards away to his left and seemed to be firing into the interior of the camp and the bullets seemed to be passing just above his middle. It might have been further from him but it seemed to him then that he could even feel the heat radiated from the hot leads. What that gunner was firing or aiming at no one will ever know. There was also a tussle a few yards to his left, followed by three pistol shots, a groan and then a dull thud on the ground. The commotion went on for about two hours. When silence reigned again Dun got up and, with his two-cell torch shielded for fear of drawing fire on him, he began to take stock of his men. There were two dead bodies in his area, one of whom looked from the shielded light identical to his Corporal Clerk by the name of Hla Tin. Expressing his sympathy and regret, he also remarked that the poor fellow had not heard his orders to lie flat and still on the ground and that he might have been running about all through that fire. Just then the second thought occurred to him of calling out his name aloud to make certain and that he might have been deceived by the shaded light. So he called out, "Hla Tin, Hla Tin." Sure enough, not five yards away came the reply, "Yes Sir $s "$ Poor chap, he was so stunned with all what had happened thats although he all the time heard his Major's remarks about him, it just did not occur to him to speak out and say that he was still alive. It may be interesting to know that this Corporal and Dun had been classmates at the Government High School, Bassein, years ago. Although there was a difference in ranks and also in race, they remained close friends with mutual respect and regard until the end of war, when the Corporal took his release and went back to civilian life.

Thereafters there was only one more incident before Dun and his men reached Imphal, and it only concerned Dun personally. That was at 82 miles camp ImphalTiddim Road. One early mornings a Japanese recce plane came over and no one knew it was the Japanese recce plane, until the Bofors opened up. The same evening the Japs shelled the camp heavily from a hilltop. Many shells fell within the camp. Naturally some men got jittery and moving from cover to cover, as shells fell near thems To give them confidence and also to check defence positions of the camp, in case an attack followed the shelling, Dun and another Major on the staff went round and telling them to stay put in their trenches. Shell after shell came over, most of which fell beyond the camp. While thus going round telling the men to keep their positions and naturally trying to look bold and brave before the men, Dun at the same time kept one of his ears always in touch with the boom on the far away hill, and then the shoo-o as the shell went past overhead and then bang beyond. He had heard from his friends that the shell that could be heard had already passed and that there was nothing to fears and that the one that could not be heard was likely to get one. Shelling continued as they walked rounds and when they came to a certain area, one shell exploded rather close to the perimeter. Both the Majors still looked brave. Meanwhile a Subadar (a Senior Viceroy Commissioned Officer) appeared from nowhere and ran right across their front to another cover, almost bent in double and on all fours. This officers' action annoyed Dun so much that he hit him with his cane right on the buttock and also gave him 
a few words of displeasure. These types of officer are usually soldiers of long service and outstanding ability and courage and had been the backbone of the Indian Army for generations and seldom, if ever, would act in such manner. In this case, the officer was comparatively young and from administrative service and no doubt only a wartime soldier.

The two officers continued their round and so did the Japanese shelling, with not much change in accuracy. By this time the Subadar was left several hundred yards behind. Just then there was another boom from the same direction, but slightly fainter, and naturally Dun was waiting for the shoo-oo and bang beyond. But it never came; several seconds went by; Dun began to get cold feet and felt as if the shell was bursting on him any moment, and also something was telling him that it was bursting, bursting, dive into the trench; so much so that his cowardice got the better of him. Therefore he dived into the nearest trench for no rhyme or reason and was closely followed by his brother officer behind him. That shell never came either as a dud or live. Dun felt like going back and apologising to the Subadar and telling him that he was no better; nevertheless, the two officers just kept it a secret between them and have had a quiet laugh about it on several occasions.

The 17 Division withdrew right into the plain of Imphal, still holding the strategic heights and positions on the line of advance of the Japanese. Other Divisions did the same, surrounding the Imphal basin. As a result, all our troops were in the plain and strategic heights, and the enemy remained in the fastnesses. Any Japanese unit that ventured into the plain was killed off piecemeal. There had been much severe fighting around Imphal which has already been penned by several writers. One night a strong force of Japanese bypassed the outer ring of defence and came in and occupied part of the hill only a few hundred yards away from $17 \mathrm{Div}$. HQ. Fortunately the highest point of that hill or knoll happened to be held by our troops, by one of the best regiments of the Indian Army which had proved itself on many, many occasions. The strength of our troops on that hill was only a platoon, and that of the attacking enemy was at least a Company; but they held the enemy and caused severe damage to them, so much so that the enemy gave up his attempt to subdue that post and bypassed it and dug in on the other side of the hill as dawn was approaching. This is by no means to discredit the fighting qualities of the Japanese troops. Because they had to be literally killed off to the last man before they were considered harmless. So far as it can be remembered now, the attempt to oust that particular party, started with a Company's attack from assorted troops that could be raised from Headquarters' own troops, led by a young Captain A.D.C. to the General by the name of Cummings, a close associate of Dun. From the early stages of the attack he was hit but on a non-vital spot and, though bleeding profusely and disabled somewhat, he did not stop there but led his men forward. Since he must have been conspicuous as an officer among the Indian soldiers, no doubt the enemy concentrated their fire on him as their prime target, because he soon got another one, and this time on a vital spot. And his one and only last word was "Tell Mother.s" Dun felt absolutely rotten when he heard the story of this young officer's death. He often wondered if this young officer had any connections with Colonel Cummings, B rig. later, who won the V.C. in Malaya. His exploit though little, yet his courage was not the less. After all what more courage and valour can a soldier have than to go unto the end.

Imphal, as previously stated, is a basin dotted with many villages surrounded by paddy fields. As it was in the middle of the rains nearly the whole plain was under water except the roads leading to the Chin Hills and Tamu and a few patches where there are knolls and high ground. Once off the road or high ground one is 
obliged to walk in knee-deep water and also sometimes ankle-deep mud. Throughout that period of siegen one's feet were invariably in wet bootsn in whichn when on a jobn one of ten had to sleep. Under such conditionsn and specially when they dragged on for five or six monthsn one did get tired and irritated, however tough and good a disciplinarian one might be. Of coursen that was what Dun felt from his own experience and his own state of mind; if any other soldier felt different he has no reason to quarrel with him. As an Intelligence Corpsn Dun and his men had little to do under such circumstances and conditionsn Therefore he once again took turns in providing standing patrol on strategic heightsn relieving the infantry from their hardpressed dutiesn Dun himself spent his time in headquarters taking turns as a duty officer. When not on dutyn he would visit his men and stay with them as time permitted. One dayn whilst he was acting as a Duty Officer and dealing with various matters from phone calls to petty things that were within the capacity of a Duty Officern one of his contemporaries from Div. HQ came back from his breakfast in a cheery mood and whistling gaily. No doubt he was also in a teasing mood. This of ficer came into his of fice and held Dun by the neck under his huge arm and teasingly shook him to and fro. His action annoyed Dun so much that he shook him off so violently that he fell backward on his haunches with Dun falling on top of himn at the same time giving him a few words of displeasure. There was no doubt that he was caught by surprise and never thought Dun would react in that mannern it not being the first time he teased him that way. Moreovern he was a big made mann a near six footer and almost square in thickness. The young big fellow was no doubt in the same frame of mind and also lost his temper. Because while Dun was thus falling on top of himn he just put his two big feet in his tummy and kicked him clean of him and sat on Dun's chesth pinning him down on the floor. Only then sense came back to them andn realizing what fools they had beenn they apologized in turn and shook hands for losing their temper over such a trivial thing. The young fellow's name was Hugh Longn a Captain and an intelligence officer of the Div. No doubt Hugh will have a quiet laugh on reading this accountn recollecting all the pleasant side of things that took place in the $H Q$ of the "Black Cats" Division.

Whilst the above Division was under this siege all the non-essential personnel were flown out to India. The Burma Intelligence Corps was also included among the ron-essentials and sent to India Mhown for reorganization and expansion to ineet the requirement of the coming push into Burma. By that timen all Burmesespeaking personneln including some of 2/20 Burma Riflesn were absorbed into the B.I.C. While his men were flown out Dun was detained by his General to do a special reconnaissance patrol with a section of Gurkhas. From the Headquartersh which were more or less at the centre of Imphal plainn to the foothills the distance must have been about two miles. Being open paddy fields there was little or no cover under which to move up to the foothillsn and the enemy who was sitting on a high hill had no doubt been watching all the time as Dun and his Gurkhas splashed their way through mud and water. On arriving at the foothillsn the patrol rested a littlen while its Commander studied his map and made plans for the approachn The patrol went up a trackn slightly overgrown and little usedn They got up to the first low hill without any incidentn but on reaching the second ridgen they came face to face with about one platoon of Japanese, with a fairly wide valley between them. Both were on the moven and no doubt it was a surprise meeting which was a blessing for the recee. patrol.n If notn the enemy could have waited at a spot of their own choosing and killed or captured the lot by a well planned ambush. Howevern this surprise meeting caused both parties to dive for cover and disappear like jungle fowl in the tall grass. Dun with his section of Gurkhas all around him were within whispering distancen In order to conceal their positionn he told them to lie still and not to fire on any account, but to be ready for instant 
action with both fire and bayonet in case the Japanese came and beat them out of the tall grass with their superior number. Judging from the strength of the enemy, it had either been sent out on the usual fighting patrol or else specially to deal with Dun's partys What Dun feared most at that moment was to be blasted out of the tall grass by 2" mortar shells and grenades from dischargers, as, with that number, they were bound to carry them. Dun and his party crawled back below the skyline and moved to another position a safe distance from grenades and 2 " mortar shells, away from where they made their disappearance. From there they remained to observe the next move of the enemys There was not any movement from them, but after half an hour or so two sJapanese heads popped up above the grass, no doubt for a better view to see what their enemy was doings One of the young Gurkhas gently raised his rifle and took aims Dun gripped his arm and shook his head meaning to tell him not to fire. The young boy smilingly lowered his rifle and said, "Miss nahin karega Sahib," meaning, "I won't miss him Sir." Dun personally thought the boy had no intention of disobeying his orders but was just trying to aim at the target, as these excellent little fellows were always itching to kill their enemy whenever opportunity presented itself.

The patrol waited until dusk, but the enemy made no movement forward; then night came with the task still unaccomplished, but to follow the same track would have been a suicidal act, since the plan of the patrol had been given away by that unexpected meetings To go across the country was out of the question in such a countrys There was nothing else one could do but to wait for the daylight. Just in case the enemy ventured forward, Dun closed his men astride the track, some distance below the crest, so that they could see the enemy coming over the skyline, with prearranged fire-orders and rendezvous etc. One man was sent back to report the incident to $\mathrm{HQ}$ and also the plan to push on across countrys Since they made no forward move, their plan might be to sit on all the tracks, which were not many, to ambush and stop the enemy from moving into their domains It was certainly not an easy job, through thick, tall grass and brush of ten interwoven with ground creepers. To get to the objective, the patrol must get over a very high hill with several smaller ones and ravines betweens Progress was very slow indeed. Having ploughed through this thickness for some hours and when the sun was well over the horizon, they came into some sort of a track which could originally have been a game track and later used by the natives there who were hiding in the jungles because of the war. As it led in the general direction of the objective, it appeared to be a GOD send for the patrol. Following this track for some distance once again they came face to face with one of the locals, who no doubt was forging back towards his village to a hidden store of his or theirss $\mathrm{He}$ responded to the signal to come forward and made no attempt to run aways Maybe he recognised his own government troops and not the Japaneses The man seemed to understand no language which Dun and his men knews However, with a few words of Manipuri, Naga, Hindustani, and a good number of signs, he seemed to have some idea of what the patrol was afters When the name of the village was mentioned to him, he straight away pointed at it, where a hut could be seen from where they were. He was made a guide there and then; with a few rupee notes waving before his eyes, he appeared to be quite willing, and made no protest either by words or signss The patrol trudged on until evening when they came to a very deep and broad ravine;swhere the guide pointed to "Tinkai-Tinkai," which was the objective and the village, where the patrol was to go and reconnoitre and report as to the presence or otherwise of the enemys It seemed close enough with binoculars, so the patrol lay observing from this side of the ravine. They saw nothing for a long time. But late in the evening some forty or fifty Japanese came and disappeared into the villages With such information obtained, the patrol came back and reported as to the presence of the enemys Not very 
long after the report was made, down came belching the big guns on the spot where dust and smoke were visibly rising and could be seen from headquarters. This was when Dun's downfall came. All the time he was pleased for accomplishing the orders given to him by his General who no doubt was watching the Japanese blown to smithereens by his gunmen. But when he saw that the shells exploded not quite where he wanteds he sent for Dun and asked, "Is that where you saw the enemy?" "Yes Sir," came the reply. "They must be passengers," said the general, evidently not pleased, because the village he wanted to blow up was on the other side of the spur. The snag in these jungles was and still is that the village doesn't remain in the same place for many years. There may be an offshoot in three or four years because of a clash of personalities between the elders $\$$ or else the whole village may move to a new spot for new taungyas or hill cultivation. Dun was so disappointed when he realized that he had not actually accomplished his General's orders and felt that he had fallen short of his expectations. He remembered what his Company Commander, now his Divisional Commander, once said to him, "Smiths it is a great thing to have someone to ask to do something and be able to sit back and feel confident that it will be done.s" No doubt he was referring to Dun's work and the confidence he had in him, then (at the Indian Military Academy).

With the failure of his mission on the one hand and tired of the life of mud and water on the other, plus the fact he was now left alone with no unit of his own, Dun went to his General and asked for leave to join his unit, now at Mhows Central India. No doubt his General was reluctant to let him go, knowing him so long and having so much confidence in him, although he had failed him this time. All he said wass "Do you want to go?" and Dun, with his inward emotions to do or not to do sort of thing, the failure of his mission had the better of him and after a few er--er, came out his reply, "Yes please Sir." So his General let him go with a few drinks in the General's basha or huts and also presented him with a packet of "Hunter's" cigars as a parting present. So parted the two soldiers of the hills, and never met again since. But their reciprocal love and regard remain unto this day. Once again Dun headed straight for Calcutta and a few weeks of relaxation and beating it up like he was again in form and had forgotten all his disappointments and tiredness. 
CHAPTER 8

REORGANIZATION, TRAINING AT MHOW, CENTRAL INDIA

He rejoined his unit at Mhows Central India. A very pleasant little place, with beautiful weathers a nice club and friendly people, mostly officers of the station, their wives and families. He made many friends there among both the B ritish and Indians. Once again he was popular as Smithy to all his friends. He was particularly friendly with two Indian girls who were sisters, one of whom is the wife of his brother officer of the same battalion, 2/1st Punjab Regt. There was a story behind why they were so friendly. Dun and Rego were great pals. What made the two become close friends was no doubt their physical build. They were of the same height and build and both were only a shade over five feet. To be so short and small in the Punjab Regiment where nearly all officers and men were six footers or nearly six feet tall, each (Dun and Rego) had at least the other to console him for not being the smallest man in the battalion. Rego left the battalion to join the Ordinance Corps before Dun left to join the Burma Military Police. They parted for well over five years, when they met again at Mhow, which was Rego's hometown. Rego threw a big party in the club soon after he came home on leave. Naturally he invited his best pal Dun. This was where he met Mrs. Rego and her sister. As would be expected, Rego was full of praise for his pal for being simple, honest, and having all the virtues of a gentlemans until Dun invited his sister-inlaw to a dance at the next club night at that very party. Rego said to his Mrs. that his best chum might no be so simple after alls No doubt of course, it was all his joke, as he heard it from no other than from Mrs. Rego herself. A very lovable and charming friend indeed.

After all the ordeals of the 1942 withdrawal and subsequent siege of Imphal, it made all the difference to be in such a nice place as Mhow, with real friends and kindly acquaintances. It was so pleasant and cheering for Dun that the two months he spent at Mhow will always remain as one of the brightest spot in his life. 


\section{CHAPTER 9}

POSTED TO 7TH DIV., REOCCUPATION OF BURMA

Two months of such a peaceful life, do make a soldier feel like being active once more. Just then the push into Burma was ons and one or two Divisions had already got across the Chindwin. Dun was given a new unit, this time consisting of nearly all the races of Burmas but the majority were Karens who were seasoned and battle-tested by no other person than the famous General Wingate in his two expeditions into Burmas Because nearly all the Karens who were now with him came from the 2/20th Burma Rifles, was Dun pleased? There was no word to express it, as he was looking forward to what he would do as they got deeper into Burma and nearing his home. By the end of October 1944 Dun and his men were shunted out to join the 7th Indian Division which was detailed to secure one of the bridgeheads on the Irrawaddy. They joined this Division at Tamu. He had a very pleasant surprise on reporting at the Divs $\mathrm{HQ}$, because there he found his new Division Commander was no other person than his Commandant at the Staff College, General Evans, who remembered him well. Unlike all other generals, who usually wore several rows of ribbons, Dun remembered having seen General Evans wearing only one piece of ribbon then, and what a medal or ribbon! It was D.S.O. and bar. There is no doubt, of course, he has several rows now. Soon after he joined them, the above division started bulldozing down the Gangaw Valley. It met with no serious opposition until it got to Pakokku at the crossing at Nyaungoo. During this time Dun and his men really came into their own; they were in the centre of Burma and among the Burmese propers They could give some useful information to the Division by patrolling and sifting information from captured prisoners, suspected locals, and agents. Dun was asked to find out about the availability of boats and of the enemy on the opposite side of the bank at the northern end of Pakokku, which was discreetly done to make the locals think that the crossing was taking place there, and no doubt such a rumour would float across the Irrawaddy to the Japanese through their agents, while the actual crossing was planned several miles to the south at a big village called Myitche. Dun lost a very fine young Corporal at this crossing. He was with one of the leading parties and, as they were nearing the other bank, their outboard motor failed and they drifted down right across the enemy's front, like sitting ducks.s This young Corporal was the son of an old Karen pioneer in the Army, Honorary Lieutenant Bo Khin Po in the Burma Sappers and Miners, the first Karen who ever rose to rank. The old man was still alive and in his nineties when Dun got back to Bassein to raise the 2 nd. Karen Rifles in 1946.

The 7th Div. having secured the bridgehead, down came the 17th Div. (The Black Cats) to leapfrog, and then capture Meiktila. Dun went to call on his old General at the crossing but unfortunately missed him, and they never met again after their parting at Imphal.

If our withdrawal in 1942 was swift our advance in 1945 was just as swift, if not faster. Division after division hooking left and right and town after town fallings Our Commanders and their troops really had the measure of the Japanese this times Unlike 1942 when the enemy was superior in numbers to us, both on land and airs this time it was the opposites both in quality and quantity. 
The writer has not the actual figures but, by guess and memory, the number of men who all fought the Japanese might be well over a millions if all regulars and irregulars were numbered and not forgetting our allies the Chinese and the Americans. There are some people today in Burma who are still apt to boast and claim the credit for driving the Japanese out of the country. When Dun hears these things it gives him a mixture of feeling which make him feel like crying and laughing, because he never heard such tripe and nonsense and he feels so sorry for his countrymen who are so vain and pathetically ignorant to boast about such vain glory. Of course any form of assistance counts in victory; but without it, although victory may be delayed a little longer, it would happen in any case.

The momentum of the drive towards Rangoon was so swift and weighty that a large formation of the Japanese was cut off on the west bank of Irrawaddy when Rangoon was taken. Before Rangoon was occupied it seemed to Dun that there was a plan for the capture of such towns as Henzada and Bassein, because he was ordered to lay on detailed intelligence on these towns. Dun sent two of his Karen boys who came from these areas and who knew the surroundings well. On the appointed day two fighters were sent off to observe the agreed signal to be given by the two men. The aircraft came back with the information that the towns were clear of the enemy. As a result, or at least that was what he thought, the attack on these towns was put off, to his great disappointment. He was looking forward so much for this particular operation, not so much because of his eagerness for a fight, but to contact his wife and children, who were somewhere in this area, and of whose fate under the Japanese occupation he had not the faintest idea at that time.

As the Japanese were still in considerable strength on that sides Dun got a brainwave and requested his Division to allow him and his men to conduct a long range patrol and gather all information about the enemy. He was dissuaded at first owing to administrative difficulties, but later was allowed, when he assured the Division that he could live on the country and be independent and self supporting.

They landed at Henzada one early morning and found thestown jointly occupied by B .I $\mathscr{A}$. and Karen volunteers, the latter mainly ex-soldiers who had been left behind, many being personally known to Dun. Fortunately, the B.I.A. and the Karens who were deadly enemies were now allies against the Japanese. The Karen volunteers and the Karen population were certainly pleased and greatly heartened by the arrival of Dun Force. In the evening there was a feast for all given by the Karens in honour of Dun Forces This was most welcomed by Dun and his men, who had been living on tinned food and dehydrated rations for the better part of the wars especially when the Karen delicacies were cooked and prepared in the Karens' own way. Thereafter followed some sort of a concert as an entertainment for thems mostly vocal and instrumental items. A welcome speech was given by a lady teacher by the name of Thramu Vera who was at her prime and not bad looking. Dun was greatly amused when in her speech she compared his force with that of Gideon. At the same time she is to be admired for having such pride and confidence in her own people.

Such information as could be obtained from locals and agents, such as the enemy's line of withdrawal, strength, morale and public opinion etc $s$, was passed on to Div. HQ. Although the Japanese were still in considerable strength they withdrew in small but effective fighting unitss avoiding rail and main roadss $B$ ut they followed more or less the line of Bassein River towards Prome where they concentrated and crossed. 
A good many were killed off at this crossing and those who got through once again concentrated in the Pegu Yoma. But more got killed when they broke through the Rangoon-Mandalay trunk road.

Having stayed two days at Henzada the patrol moved south towards Bassein. By that times according to local information, the bulk of the Japanese retreating force was well north of Dun Force; and the stragglers avoided them as best they could. No doubt they got as much news of the patrol as the patrol got about them. One thing was certain at that time and that was that the sway of the Japanese and their henchmen was still strong on the public, specially in small towns and villages. They were not quite certain if the Japanese were really beaten and if the B ritish were really coming back for good. When we paid for our local supplies in rupees, which was the currency before the Japanese, the locals insisted on being paid in Japanese Burma notess When reasoning with them faileds Dun Force gladly obliged thems as by this time the patrol had already collected a few bagfuls of these notes. By this time some of the men even used it in lieu of bromo paper. This little excursion of Dun Force, although gaining little for the execution of the wars yet it served as a very useful flag-march. The people who were left behind the patrol at each stage came to be convinced that the Japanese rule and tyranny had really come to an end. Half way to Bassein Dun headed straight away to Kyonpyaws a small township only a couple of miles from his own village. There he found the place also occupied by Karen volunteers commanded by Captain 0 . Po, son of the grand old man of the Karens, Dr. San C. Po. This officer got wounded at Yenangyaung on our withdrawal and was left behind somewhere near Monywa. He recovered and made his way home to Bassein and now was on the job once more. Since Bassein was clear of the enemy there was no point of going there, so Dun concentrated on his prime objectives which was to find his wife and children. The objective was gained with only one casualty, that was the youngest child who had died through lack of medicine in the early days of the Japanese occupation.

Meanwhile, behind at Headquarters a fool of an officer spread the alarm that Dun was bound to have a bloody revenge on the Burmese for their atrocities in the early stages of the war. As a result messages were flashed to all units who were likely to be able to contact him for him to return to Headquarters forthwith. Having collected his wife and children, he had to speed back to Rangoon. Not very long after that he was posted to Bassein to raise a new Karen battalion where by this time the government had already been reestablished. His promotion to higher ranks was even more rapid than that through the lower ranks. His Lieutenant-Colonelcy hardly came out in the Gazette before he was made a full Colonel as a Deputy Inspector General, and after less than a year in that rank he rose to Brigadier to be the Deputy G.O.C. of the Burma Army. A few months before Independence he became Major-General as G.O.C. of the Burma Army and took over from Major-General Thomas C.B.D.S.O. M.C. who was the last British officer to command the postwar Burma Army . 
CHAPTER 10

\section{CAREER WITH POSTWAR BURMA ARMY TO SELF-IMPOSED EXILE, KACHIN STATE}

Not very long after Independence the country was in a state of turmoil caused by those who thought they deserved the lion's share but did not get it. Thereafter followed the assassination of the leaders, and rebellion broke out from multicoloured insurgents. Conditions, law and order deteriorated rapidly. Many Police Stations fell to the insurgents, specially in the Insein District. It was then thought necessary to put some districts under military administration, when Dun was again promoted to a Lieut-General and appointed Supreme-Commander of All Burma's Armed Forces, including Police, irregulars and all who could hold arms in defence of the Union of Burma. His rapid promotions were thanks to the political changes and the multi-coloured insurgents. But inwardly how he longed for those days when he was only a Second-Lieutenant and might have been fast asleep on the lawns on holidays, and yet would still be saluted by a passing sepoy or N.C.O. But now things were so different, whatever his designation and rank, with the assassination of the V.I.P.'s and the desertion of Communist sympathizers among the Burmese troops under his commands He could only count on the hill tribes (Chins, Kachins, Gurkhas and Karens) even for his own security. As for the Burmese troops, only those who were personally known to him could be trusted because, with their various backgrounds in politics, he was completely at a loss whom to trusts The Premier Thakin Nu himself had to have Chin troops for his protection at that time. In any movement outside one's homes one had to be escorted by at least a few bodyguards. From his home, the "Flagstaff House,s" Mingaladon to the War Office, Rangoon, Dun had to have a jeep-load of escorts, one leading and the other following, and the route also had to be cleared by intelligence groups beforehand. Such was the condition of life for the G.O.C., Supreme Commander and what not of the Burma Armed Forces at this period.s There was a rumour of various threats from the deserters to various people for military actions taken after their desertion. It must have been pretty awful for the Burmese ministers and officials who could not trust even their own kind. Dun at least could have complete confidence in his own Karens and the hill tribes. So, looking back, it was not too bad for him after all, in comparison with others who went through this transitional period.

Conditions, law and order deteriorated rapidly, many Police Stations had to be closed down. Rangoon itself was threatened from all sides. There were hardly enough troops in the Station (Rangoon) under the Station Commander's hand to protect vital installations and Rangoon itself, let alone having any effective striking force. To make things worses some Burmese papers, either deliberately or ignorantly, published some irresponsible news and articles which tended to aggravate the tension between the Karens and Burmese which was already then at a critical stage. The Burmese Government seemed to do nothing to stop them. Prome fell to the 1st Burma Rifles (all Burmese) who mutinied from Thayetmyo in sympathy with the Communists. The 2nd. Karen Rifles which was at Meiktila was ordered to retake Prome from the Communists from the north, in conjunction with the 1st. Emergency Kachin Rifles which had to be flown down from Myitkyina to 
advance from the south. The two battalions retook Prome after stiff resistance to both sides from the 1st. Burma Rifles and their Communist alliesn

It must be remembered that the 1stn Burma Rifles was a regular battalion, equally well armed and trained as the two attacking battalions (one Kachin and one Karen) $n$ As they were all Burmese and the population of the area was also all Burmesen the public were naturally on the side of the Burmesen So, after Prome was retaken and when all was quietn many complaints came in from some politicians that the action of the attacking troops (2nd. Karens \& 1st. E. Kachins) particularly the Karen battalionn was unreasonably harsh on the Burmese populationn deliberately ignoring the fact thatn had the Communists overrun the country, a good many of those who complained would have had their throats slit by their now beloved Burmese Communists. How it reminded Dun of a Karen saying about his Burmese neighbourn "You tread on his odure he sues you for damage and when he treads on yoursn he sues you all the same for dirtying his feetn" The Karen sayings are nearly always cruden but always very appropriate and effectiven as indeed in this casen

The 2nd. Karen Rifles was left to garrison the area while the 1st. Emergency Kachins was pulled in to Rangoon to form a reserven but had to be diverted to Thaton and Moulmein to deal with a new situation theren By this time, isolated communal clashes between the Burmese and Karens had already taken placen and the Karen Union Military Police of these two towns had taken the law into their own handsn

At this juncture, the Karen National Defence Organization (K.N.D.O.), at least ten thousand strong and expandingn was like an atomic energyn in the possession of any big power, that can be put in use for both peace or war. Being purely a professional soldier and true to his oath of allegiancen Dun wanted to use them for peacen So he put up a proposal to the Prime Minister, who was also defence minister then, that he could make use of the K.N.D.O.'s, if the P.M. agreed, to reoccupy and garrison areas where he could not meet with his own regular troopsn taking full responsibility for their loyalty and reliability. The Prime Minister agreed, and thus the K.N.D.O.'s were given several tasks in forming an outer ring of defence for Rangoon. Most important of all was the reoccupation of Twante townn a riverine gate to the delta towns and Upper Burma both to and from Rangoonn This little town had fallen severalntimes to the Communists and each time was retaken by regular troops, and, when conditions returned to normal, it was handed back to the civil authorities and the policen only to fall back into the hands of the rebels each time. There were literally no regular troops to garrison it, hence Dun's request to utilize the services of the K.N.D.O.'s. To prove their worthn Dun ordered them to retake Twante which was once more in the hands of the Communists. This was done with their own resourcesnand without any support from regular arms other than river transport. They wrested the town from the Communists' hands and garrisoned itn in accordance with their given orders. Alas! some vernacular papers, no doubt inspired by unscrupulous politicians, came out with bold headlines about atrocities committed by the Karens against the Burmese publicn K.N.D.O. leaders and the Commander of the garrison were summoned to the War Office to answer the accusations that appeared in the papersn They not only denied the accusations but also requested an impartial enquiry committee to enquire into the matter. A Committee of three officers was duly sent out; a president and two membersn The President was a senior Police Officer (Deputy Inspector General of Police) and an Anglo-Burman. The two members were Captains in the Army, one Karen and one Burmese. The Committee took evidence from all races living in the town. The report revealed that the accusations were false and without foundation. A copy was sent to the Home Ministryn but no action was 
taken to stop the papers. Communal tension between the Karens and Burmese remained high, and clashes between the two occurred more frequently. Dun's last effort to avoid a communal clashs which now seemed inevitable and imminent, was to call a conference of allshis senior officers, battalion commanders and above. He briefed them about the seriousness of the situation between the Karens and the Burmese and how necessary it was for the Army to be absolutely impartial in their dealings with any situation that they might be called upon to deal with. One or two senior officers (Burmese) tried to argue that it was not communal but politicals but, when he pointed out to them a few instances that had already taken place, such as the massacre of Palaw in Tavoy district on X'mas night, and others when buses were stopped by Burmese irregulars, when Karen passengers were molested with a few cases of detention and some never returned home while other nationalities were left alones they were then silent. It will be remembered that nearly all the Burmese soldiers were from the B.I.A., a political organization that even boasted that they had driven out both the B ritish and the Japanese at their whim and gained Independence for Burma. Therefore those few Burmese officers who repudiated their G.O.C. were no doubt imbued to the hilt with political ideologies, and should be in politics rather than in uniforms.

In actual fact the cat was out of the bag the evening before. Whilst he was talking to his two Brigadiers, Let-ya and Kyadoe, his then Deputy came in; Dun, doubting his capacity to read orders, briefed him about the conference that was to take place. He listened quite attentively, but at the end he got up and said, "If only the Karens had started two months ago it would be alright for them, not now," and left. The two Brigadiers were just left there, stunned at such an attitude and behaviour. No doubt it would look strange and funny in other countries for a deputy to be so brazen as to make such remarks in the face of his Commander, but nothing was strange in Burma then. That very night Ahlone Karen quarters was ostensibly searched for arms, and was not only put to the torch but also all kinds of firearms were blazing in it. All the quarters were reduced to ashes, but fortunately only one or two deaths were reported from this outrage. The same morning, Thamaing Karen quarters was also subjected to the same fate. Early that morning Dun received a telephone call from one of the elders from Thamaing about the incident and the catastrophe that was taking place. Dun at once phoned up the Premier $\mathrm{U} \mathrm{Nu}$ (Thakin $\mathrm{Nu}$ then), who was also Defence Minister, requesting him to intervenes not knowing under whose orders and directions this was dones although he was a supreme of all Burma's Armed Forces. The Prime Minister replied that he would and that he was going to contact someone whom he nameds who was no other than Dun's deputys So it must be presumed that Dun's deputy was actually conducting that particular operation which started the wholesale shooting war between the Karens and the Burmese. Whatever the motives of the authors of this communal clash, no doubt they realise nowsthat they gained their objective alright, but at the cost of many hundreds and thousands of lives, both Karen and Burmese, specially those living in the outlying districts and villages. When news of the attacks on Ahlone and Thamaing reached the Karen troops at Mingaladon, most of them pushed off to defend their kith and kin in those areas. The shooting war continued and spread to Insein and also to many other districts. Under the circumstances it was impossible for Dun to remain in office, and therefore he resigned that very morning. There was an offer of long leave and full pay etc. But Dun just wouldn't take it and resigned, and went on his self-imposed exile to Myitkyina in the Kachin State where there are few Karens and Burmese. 


\section{Self-Imposed Exile}

Early next morning Dun sent his A.D.C. (Captain Lloyd Khaing) to the airfield not far from his residence, to make sure that everything was laid on for his journey. The A.D.C. went up and down the runway in his jeep several times without any untoward incident. At about $7 \mathrm{a} . \mathrm{m}$. the General and his family started from the house in two vehicles, he and his wife, four children and two servant girls in his staff car with his flag flying as usual, and the luggage following in a $15 \mathrm{cwt}$ truck with his orderly and few men to help loading. The A.D.C. in his own jeep led the convoy of three vehicles on the same route that he had been on an hour or so ago. As soon as the General's car arrived in the middle of the runway every weapon guarding the airfield seemed to open up on them, including 2 rounds of 2 " mortars. Dun ordered his driver to turn round and run the gauntlet until they disappeared out of sight. When they reached a safe place Dun was more than relieved to see all his household safe and not even a scratch on his 8-seater car. It was now clear that the act was deliberate, and it was an attempt on his life. The rumour and suspicions which had warned him to be careful now became a reality. He drove to his Dist. Commander's residence and asked him to ring up the garrison Commander and tell him a few things. At the District Commander's house there was, fortunately, an ambulance of civilian type which the General took, and he proceeded to board the plane via a different route. Till then his plan was to disembark at Meiktila and proceed thence by road to Kalaw, in accordance with his former programme. During the flight and just before he landed at Meiktila he was moved within not to go to Kalaws but to continue to Maymyo (the destination of the plane), with a view to going to Myitkyina from there.

Although his visit this time was under different circumstances, he was received by his North Burma District Commander (Brig. Kyaw Zaw) with all courtesy and due respect as on previous occasions. At the airfield, Kyaw $\mathrm{Zaw}$ reported to him that he had disarmed and interned all Karen Officers and men, in accordance with orders received from the War Office, and this was the first time that Dun learned of the dirty tricks that had been played behind his back. Now that he had resigned there was nothing he could do but look on and let the devil complete his job. A few days after he arrived in Maymyo he saw in one of the papers that an attempt had been made on Dun's life and the would-be assassins were the Karen rebels. He thought, whosoever was responsible for that bit of news had nicely and beautifully twisted it. In actual fact, just before he boarded the plane he ordered the garrison Commander to come before him in the presence of some fifteen senior officers, both Karen and Burmese, where no claim could be made as a mistake. The garrison Commander duly arrived, with a truckload of his men, the very officer who had been responsible for the General's security for the last six months for part of that wooded country from the Flagstaff House to the War Office in Rangoon and for whom Dun had gone out of his way to have him commissioned in the Army. He came in, saluted and apologized for having made a mistake. $\mathrm{O} . \mathrm{K}$. it was a mistake and no damage was done, and he was dismissed to go back to his duty.

At Maymyo things went on quite normally for some time. In fact things were so peaceful that Lt./Col. Wallie Unger got married and Din had to act as a proxy father to the brides One day there was a hell of a lot of firing all over Maymyo. Just as the general was wondering what all the firing was about, Wallie Unger came in from Dist. HQ. Knowing him quite intimately the general asked,

"What's all the firing Wallie?"

"The Karens are taking over the town Sir.s 
"Don't be kidding $s^{\prime \prime}$

"No Sir, I mean it.s"

"But how the hell, they had all been disarmed and wired in."

"That's what I learnt at the District HQ Sir $s^{\prime \prime}$

"Alright, now go back and find out $s$ "

"Very well Sir," he saluted and went off.

Wallie Unger came back and confirmed what he had heards and added that he was challenged, and nearly got shot near his own bungalow. He said that they were all Karens, some of whom he knew well.

"Are you sure about it Wallie?"

"I swear upon my word of honour, Sir, they were all Karens.s"

"Alrights go back to them again and tell them that it is from me as a Karen that I don't want to hear of any atrocities."

"Very well Sir," said Wallie and disappeared once more.

He came back a few minutes later and said that the Karens promised not to do anything of the sort. Later ons Wallie asked his General,

"What shall I do Sir?"

"Well, Wallie, you are still bound by your oath of allegiance; therefore, if you can do it, fight it out with the Karens who are taking over the town."

Poor Wallie Ungers being a Eurasian he had neither Burmese nor Karens to fight it out. Although he was the most senior officer in the station at that times the station was under command of a comparatively junior Burmese officers a Majors though Unger was a Lieut. Colonel. No wonder the town was surrendered without a fight even to the people who were already disarmed and put behind wires. The beauty of it all was that Lieut Colonel W. Unger was locked up for several years for no fault of his.

- Before evening it was all over. Maymyo was completely taken over by the Karens and Kachins.

When Toungoo fell to the Karen rebels the plan was to retake it with the 1st. Karen Rifles and 1st. Kachin Rifles who were then still loyal and proper to the hilt. This would mean the suspension of operations against the Burman Communists in Pyinmana area. Since there was no alternatives as all regular troops elsewhere were fully committed, orders were sent out to that effects and Wing Commander S. Khin was sent out to contact the 1st. Karen Rifles who were then holding the airfield north of Toungoo. He contacted the 1st Karens and brought back full information of the fall of Toungoo and of the enemy etc. Accordingly, plans were made and sent out to the two battalions. The garrison of Toungoo at its fall consisted of Civil Police, Union Military Police (UMP) and Sitwundan's (B.T.F.)s the last being more of a liability than an asset so far as maintaining peace was concerneds owing to their unruly behaviour. The 1st. Karens were some six or seven miles north of the town. The garrison of the town therefore was no match for the Karen rebels supported by some old Japanese guns. Moreover, the K.N.D.O.'s consisted of mostly ex-soldiers and levies of the Japanese war, seasoned and battle testeds The General had no doubt that the town would be retaken if everything went according to his plan. But the dirty trick that had been played behind his back turned the scales completely round. By the 
time concentration of the two battalions was completes news had also reached them about the disarming and interning of Karen troops at Mandalay and Maymyos To make things worses the disarming of Karen troops was also followed by the anticipated massacre of the prisoners. Since Karen history is full of such incidents in times of old, repeated in the same fashion in 1942, and at Palaw (Mergui) in this case, the Karens have good reason to believe it. Therefore the two battalions, instead of fighting the Karen rebels, joined hands and made a dash for Mandalay and Maymyo to save their brothers and cousins.

Reinforced by the K.N.D.O.'s, the two battalions went through that bit of country like a dose of salt. As luck would have it for them, on their reaching Meiktila two dakotas unwittingly came into their hands. They commandeered the two planess and loaded them with a platoon of Kachins, commanded by a dashing young Kachin Captain by the name of Naw Seng (a winner of two Burma Gallantry medals in the Wingate show). Naw Seng and his men duly landed at Anisakan airfield near Maymyo, at a time when everybody's thoughts were far away from war and rebellions.

Dun was told later that the party arrested and disarmed everyone at the airfields including Brigadier Chit $\mathrm{K}$ hin who was then on leave. Thereafter they made a dash for Maymyo towns disarming all guards and piquets not manned by the Kachin troops. They released all the Karens from the concentration camp and also opened up the armoury for them. This was how Maymyo came into the hands of the Karens and Kachins. A successful risk executed with boldness and dashs

When it was clear to the Burman troops that the town had fallen to the Karens and Kachins, nearly all but those who were caught unarmed deserted with their arms and ammunition. The Burman irregulars made several attempts to recapture the town, but each time were beaten off. If there was any death and destruction it took place mostly in this struggle. Dun neither saw nor heard any deliberate atrocious action on any scale by either party that could be called a massacre. Incidents arising from personal enmity and civilians caught in the crossfire, or between two fires, must of course be expected. The "B" Mess where he put up with his family had many bullet scars from the attacking Burman troops. It was a miracle that none of the inmates was wounded nor killed. One evening, about a dozen rounds of $3^{\prime \prime}$ mortar shells were directed on to it from the attacking Burman troops. Dun lived in that Mess for over two weeks even before the trouble started, so the Commander of the attacking troops must have known who lived there, hence the shelling of " $B$ " Mess was nothing but a deliberate act on the part of the attacking troops.

When the Burman troops were finally beaten off by the Karens and Kachins, Maymyo remained in their hands throughout March and part of April. About the middle of April, the 3rd Kachin Rifles from Myitkyina were sent down to recapture the town, under the command of Colonel Lazum Tang who was now exalted to a local $\mathrm{B}$ rigadier.

The General heard from both sides who visited him at his residence that the two sides met like long departed friends rather than enemies, shaking hands, exchanging greetings and news, instead of shooting one another.

To start with, Lazum Tang played a nice piece of strategy. He sent in, as his envoys, influential Kachin Elders and Duwas (Chiefs) to negotiate for the evacuation of all the Kachin familiess promising to send them to their respective homes. Once the families were gone, the morale of the Kachin troops began to wane, and with more promises of leave and pardon etc. to the Kachin troops they finally cracked up. Finallys nearly all yielded to Lazum Tang's propaganda and 
deserted their Karen ally. The Karens were numerically weakened by the desertion of their ally, the Kachins. They could probably have mustered a weak battalion, with administrative troops and boys' company. However, the two opposing forces still would not attack each other, but negotiated for surrender instead. With promises of security and non-victimization etc., the Karens finally yielded to Lazum Tang's propaganda for their surrender, which earned them varying terms of imprisonment, in some cases over seven years.

The Kachins as a race are much closer to the Karens than to any other race of Burma. With the American missionaries, it was the Karens who brought them the gospel of Christ, specially in the remote areas; together with the gospel, it was also the Karens out of all the Burmese races who brought them education. Even at the time when the writer was in self-imposed exile (1949-52) there were still a number of Karen pastors and teachers in their churches and schools, even though the Kachins had a number of graduates and increasing numbers in Rangoon University.

Before closing this chapter on Maymyo, the writer wishes to record his appreciation and gratefulness to the British for their last act of Kindness done to him through the British Service Mission, especially to the Brigadier the Earl of Kaithness.

As previously stated, it was his intention to proceed to Myitkyina, away from all the Burman and Karen troubles. Now that he was caught in this turmoil, the very thing he was trying to avoid, it became impossible for him to undertake the journey now; therefore, he requested the British Service Mission to negotiate on his behalf with the Burmese Government for permission to evacuate his family to Myitkyina by air. Quite rightly the Mission was somewhat reluctant to do this, for fear of being misunderstood by the Burmese Government for having sympathy and helping the Karens, even if it was only for the evacuation of his family. Coincidentally a few Burman families, including Brigadier Kyaw Zaw's, were taking shelter under his wing. So it was agreed that the negotiation would be for the evacuation of the General's family to Myitkyina and of the Brigadier's to Rangoon. The British Service Mission not only got the permission for him but also two R.A.F. transport planes for the purpose.

The General's family went to Myitkyina while he remained at Maymyo to clear himself, not knowing the attitude of the Burmese Government to the fall of Maymyo. When the Karen troops surrendered to the 3rd. Kachin Rifles, Dun learnt from Lazum Tang that he had received orders from the Burmese Government that all Karens, civilians or otherwise, were to be arrested, except Dun. So he presumed that he was clear on the Maymyo incident and proceeded to join his family at Myitkyina where he arrived on the 19th of May 1949.

Before he joined his family, and soon after they arrived there, a special chartered plane was sent by the Burmese Government with some police officers including two of their close friends to persuade his family to return to Rangoon. The reason given was to ensure their safety and also to provide them with appropriate living quarters. But the General's wife was no fool and, being imbued with her husband's policy of "do no wrong and stand no nonsense, s' she just put her feet down and refused to budge, and also gave them a bit of her mind for the experiences she had been through since the trouble started. Fortunately the Kachin elders also stood up for her. Thus the chartered plane went back without the General's family. The reason given for the Government's action on this matter could hardly be the truth, and Dun rather thought that it was to shackle his activities by keeping his wife in their hands, especially not knowing what his 
reaction would be at the time when the success of the Karen rebellion was at its peakn

Way back at Mingaladon, the Flagstaff Housen where they had left nearly all their household belongingsn was searched and rummaged and not a few things also stolenn by who goodness alone knows. Neither the Army, the Police nor Politicians could answer his queriesn His peoplen who had been left there to look after things, were conveniently packed off to a concentration campn Out of all the stolen things from his possession, the 500 rounds of 12 . bore cartridges were the thing he valued most. The reason why will appear in a separate chapter latern He had written to all in the Army, Police and including the P.M. himself, but none of them could do anything about itn In some cases, he did not even receive repliesn

Having been at Myitkyina for a year or son the Deputy Commissioner (a Kachin) by the name of Zaw Tun invited him on one of his tours in the Upper Chindwin which abounds with all sorts of game. He accepted this invitation with gratefulnessn since it would be such a change from the monotonous life of Myitkyina townn This officer had been a Major during World War II before he took up the civil appointment. He was decorated twice with Military Cross and had more or less served under Dun before he took up his civil appointmentn because Dun was the Deputy Inspector General of the Burma Army long before this officer left the Army.

The very first night they were out in the junglen before the campfire and over a few tots of rum and various eats of jungle produce of jungle fowln green pigeons, barking deer or gyee, etc. Just then, when both were in a very good moodn and enjoying the best of the young nightn he revealed to Dun that he had seen and known him long before Dun arrived at Myitkyinan He saidn before he left the Army to become a Deputy Commissioner and while he was still a major, he saw Dun at the officers' shopn and said he was quitensurprised to see someone from Burma rise so senior in the Army (Dun was then a full Colonel). By this timen both sank about a pint each. So no secret will remain between friendsn specially of the same feathers. He said, "Sir," Dun said, "Yes"; "Do you know why I invited you to come out to the jungle?" Dun saidn "No." He saidn "I want you to nurse your old wounds and forget all your troubles." "Thank you very inuch Zaw, and I am trying to do so." "Zaw" in Kachin by the way is a descendant of a Chief, and this laddie ( $\mathrm{Zaw}$ Tun) was worth many more than the old Chiefs of his ancestors with his educationn experiencesn outlook and above all his integrity etcn

The writer has lived well over fifty years and knows pretty well all the Burmese peoples (meaning all races of Burma)n but he hasn't yet met an equal to Zaw Tun even from his own kindn the Karensn

He saidn "Sirn not long before you arrived at Myitkyinan I received an order to send you and the whole family back to Rangoon." He said, "I replied thus: It is against my conscience to carry out this ordern since I know for certain that the General has done nothing wrong heren and the only thing I saw him doing heren he went to the Church on Sundaysn or else shooting with the Kachin officers on holidays. So, please reconsider this order given to men" He continued to tell the General that he never mentioned this order received from the Burma Government because he did not want to aggravate his already hurt feelings. Fortunately the matter ended theren A very kind officern whose fairnessn justicen and impartiality in his dealings were on the lips of alln irrespective of race and creedn 
He died a few months later from Black Water fever. Many thousands of people of all nationalities from his district turned up to pay him homage at his burial. What a fine fellow he was. To the best of the author's knowledge, and although he was educated and brought up in the Christian way, he had never been baptised, in spite of his wife being a staunch Baptist. However, the most beautiful thing of all in his life was that he accepted Christ as his Saviour on his death bed, before a pastor whom he sent for and confessed about his faith and acceptance of the Saviour as he was breathing his last. 
CHAPTER 11

THE BURMAN-KAREN TROUBLES

As the sad ending of the career of "The Four Foot Colonel" was mainly due to "The Burman-Karen Troubles" after Independence, it may not be inappropriate to include a short chapter on the subject in his autobiography. It will no doubt be of interest for those who knew Burma and its people and also those who had had any connection with Burma. It is a big subject and would take a fair size book by itself. Hence the author will only represent the views of the Burmans as officially recorded, and also of the Karens, not his own but those of another Karen which the writer considers to represent the views of the bulk of the Karens.

\section{The Burmans' Point of View}

It started with the history of Burma, with the mass migration of various races. It said: "The major races can be classified into three groups: (a) Mon-Khmer; (b) Tibeto-Burman; (c) Tai-Chinese. The Mon-Khmer race comprises Mons, Palaungs and Was. The Tibeto-Burman race comprises Burmans, Arakanese, Chins and Kachins. The Tai-Chinese race comprises, Shans and Karens. The way the mammoth migration took place may be judged from the historical data as well as from the fact that up to the present time each community lives as a separate entity in its own region. Among the three races, the Mon-Khmer were the first to migrate, while the Tai-Chinese were the last. The Mon-Khmer, being followed and pressed forward by the Tibeto-Burman wave, naturally got further south until they reached the sea coast where they stood firm. Later the third and last migration took place as the Tai-Chinese moved through Yunnan to the NE of Burma; they found the former two races who had already settled down in the plains of Burma, therefore turned towards the hills of the Northern Shan States and Assam. The Karens who belonged to this Tai-Chinese race group also migrated gradually and by about 600-700 A.D. started to enter Burma along the Eastern ranges and later the Pegu-Yoma. As years rolled by they steadily came down to the plains and only recently settled down in the Pegu district and delta areas. When they arrived in the plains about 1757 A.D., Captain C.J.F.S., on page 40 of his book "British Burma and its People" says:

Their [Karens] present locality seems to indicate a migration southwards from the Chinese province of $\mathrm{Yu}$-nan. The most civilised tribe, the Sgaus, which has been long in contact with races superior to itself, has partly made its way into the plains of Pegu, and a few scattered families are to be found on the eastern slopes of Arracan Hills, but these are recent and very unimportant settlements. The real home of the Karen people is the vast series of lofty mountain ranges that lie between the great Irrawaddy and Menam rivers, and from the south of $\mathrm{Yu}$-nan Province to the extremity of the British district of Mergui in lat. $11^{\circ} \mathrm{N}$. [C. J. F. SmithForbes, British Burma and its People (Londons Murray, 1878), p. 40s]

When the British occupied Burma the Karens living in the plains were Buddhist like the Burmans. The British regime brought with it Christian missionary 
enterprise. Though strenuous attempts were made for the spread of Christianity with the help of the B ritish government, it failed to make much headway among the indigenous races of Burma including the Karens of the plains.

The causes which led to the increase in the Christian population of the plains and subsequent developments sean be found in such books as "The Loyal Karens" by D. M. Smeaton published in 1888 . On page 226 , it is stated:

In openly sanctioning and encouraging the teaching of the Christian religion to Karens, the $B$ ritish Government would be in no sense interfering with the religious freedom of the people. . . . The position is a curious and unique one. Rarely, if ever, has it been the good fortune of any Christian State to be placed in a position of such legitimate and commanding influence over the religion of a people.

Page 227: The Government should endeavour by every possible means to draw the hill Karens down to the plains, and settle them on good ricegrowing lands. . . . Grasp the children freed from killing labour, for the school, and you will very soon find the communities prosperous and happy, and you will be raising a great permanent bulwark of strength for B ritish rule.

Page 225: The last attribute of Karen nationality is--their religion. My readers will perhaps wince at the bare mention of the subject. $B$ ut in the case of the Karens the policy of Government is much simplified. We, as a Christian power, occupy common ground with the Karens in regard to religion. The Christian section have a faith identical with our own. [D. M. Smeaton, The Loyal Karens of Burma, 2nd ed. (London: Kegan Paul, Trench, Trubner, 1920).]

Similar comments can also be found in other books by Western authors. As it was the period of the growth of imperialism, the main concern of the rulers was the perpetuation of their control over the ruled and they accordingly promoted dissensions and splits among the indigenous races. Of Burma it will not be far from the truth to suggest that these machinations lie at the root of the present K.N.D.O. (Karen National Defence Organization) rising with a view to creating a strong impetus for the establishment of a separate Karen State.

The withdrawal of the B ritish from Burma, following the outbreak of war with Japan, was a great blow to the Karens. They had been so dependent on the B ritish that they found themselves at a loss as to what they should do.s True to their character and tradition, they remained loyal and faithful to the British who they believed right from the beginning would come back to Burma to succour them. They sat on this belief andsstarted underground resistance movements in the hills and delta areas. Unfortunately these underground movements clashed with the B.I.A. (Burına Independence A rmy) which accompanied the victorious Japanese Army, and led to two very unfortunate incidents at Papun and Myaungmya.

It is extremely strange to note that the K.N.D.O. insurrection was not a spontaneous uprising. Literally speaking, the insurrection was made up of several isolated incidents and appeared to have been dictated by the psychology of the moment and the difficulties under which the Government was placed at the time. One outstanding characteristic was the ability with which the K.N.D.O. exploited the conciliatory attitude of the Government in each incident, thereby precipitating the insurrection. They are ruthless in their methods and, like other insurgents in the country, certain leaders have little or no control over local leaders who decided the issue without reference to the central authority. 
The K.N.D.O.'s Plea for Insurrection

Like Hitler in his Lebensraumn the Karen suffered from the acute obsession that Karens inside Burma were being completely encircled from all sidesn politically and economicallyn by Burmans whon like the Americansn British and Frenchn were slowly and gradually putting a noose round the Karen race with a view to strangulating and exterminating the whole race. Like Hitlern the Karens looked for their Lebensraum in a separate Karen Staten where they hope to extend their political and economical freedom just as Hitler's Germany did in 1935. Like Hitlern the Karens believed that aggression is the only weapon for achieving their Lebensraum and upholding the mighty warlike tradition of their race. Like Hitlern they refused to believe in the sincerity of the Burmese people towards their constitutional aspirations for a separate Karen State. Like Hitlern they believed only in a war of aggressionn and they promptly launched one against the Government of Burma. In every propaganda speech they made or broadcast and in every political pamphlet they printed and circulated for home and foreign consumptionn they sang the "Swan Song" that the Burmese Government had all along been scheming to wipe out the whole Karen race.

Fortunately history never fails in its repetition and the $\mathrm{N}$ azis of Hitler's Germany would smile in their graves if they were to see the exact manifestation of their obsession for Lebensraum in speeches and leaflets. In fact the cause for the Karenistan insurrection could be traced back to the time when rabid imperialists like D. M. Smeaton started to sow the seeds of political disruptive tendencies.

Their policy of aggression began from the day when the K.N.U. (Karen National Union) decided to create a separate Karen State by force of armsn The occasion for the armed revolt came when they had organized the K.N.D.O. andn collected arms and ammo and received assurances from unscrupulous foreigners like Colonel Tulloch and company. As soon as they saw that the hands of the Government were too full with P.V.O. and Communist risings, the present K.N.D.O. rising began with their murdering innocent villagersn and burning Burmese villages. The fighting that broke out at Insein on the night of $31 \mathrm{st}$ January 1949 was only an attempt to deliver a coup-de-grace to the Governmentn which was already being embarrassed from all sides.

\section{Battle for Karenistan}

The first shot to usher in the war for Karenistan was not fired at Insein but at Toungoo. While the eight-man committee and sub-committee were frantically busy trying to find ways and means of averting the K.N.D.O. insurrection at Toungoo on 27 th of January 1949 , K.N.D.O. secret wireless transmissions hummed over the airn and the Karen U.M.P. (Union Military Police) at Basseinn following the lead given by Toungoon mutinied and seized some parts of Bassein town on 28th January 1949.

Fighting broke out between government forces and K.N.D.O.'s at Thamaing, and Khawegyan on the night of 31st January 1949, and, having been primed with drinks, K.N.D.O.'s shot and killed several innocent Burmese civilians, including women and childrenn in Insein where the uprising dragged on more than three months. Toungoo K.N.D.O.'s, who were mostly members of the 1st Karen Rifles, made a bold bid for Pegu by making a drive south but were effectively checked by the government forces which included the crack 2nd. Burma Rifles of Wingate expedition fame. 2nd Karen Rifles stationed at Prome followed suit and made a rush for Rangoonn presumably to join forces with insurgents at Inseinn but were completely beaten and broken up before they reached Tharrawaddyn When the 
Toungoo K.N.D.O.'s found their advance halted by government troops, they turned their attention to northern Burma. They brought over certain elements of the Kachin Rifles stationed at Yamethin district with all kinds of inducements, and together they marched on Meiktila on a campaign of conquest. At Meiktila two aircraft inadvertently fell into their hands and, with these two aircrafts they made a dramatic landing at Anisakan and captured Maymyo. A two-prong attack was subsequently made on Mandalay which eventually fell into their hands on 11 th March 1949. The tide of war soon turned against the K.N.D.O.'s. Bassein, Mandalay, Maymyo, Meiktila and Thazi were eventually wrested from their hands by government forces. K SN SD SOSS from Insein ultimately retreated and escaped across the Hlaing river towards Maubin and Sabudaung. K.N.D sO 's were ultimately pinned down to their erstwhile strongholds at Toungoo, in the Karenni States, and in the Thaton district from where they announced to the world through their clandestine radio that they had established their "KAWTHULAY" or Karen State.

\section{Defection of the Karen Army}

Under the British, in conformity with their policy of "Divide-et-impera,s it had never been the custom to permit class battalions of indigenous races of the Burma Army, notwithstanding the magnificent fighting qualities of the Karenss Chins and Kachins. With independence in sight to convince minority races of the sincerity of the Burmese Government's intentions towards them, the Government of Burma authorised formation of class battalions, and when Independence was declared the Karens could boast of three full battalions officered and manned exclusively by Karens. There was also one mixed battalion, commanded by a Karen Commanding Officer and with a G $\mathbf{S O S C}$, Vice Chief of Staff and Chief of Air Staff also Karens. This is a privilege no minority in any other country in the world has ever enjoyed. To do full justice to the persons concerned, the Karen G.O.C., his Vice Chief of Staff and Chief of Air Staff, like true and good soldierss remained scrupulously loyal in spite of direct or indirect influence extended on them by the Karen insurgents.

The appeal signed by Sir San C. Po, Sra Shwe Ba, U Hla Pe, Sydney Loo Nees and Saw Pe Thas and broadcast to the Karen people on the eve of the first official Karen new year's day in 1938s emphasizes that "Progressive in thinking, constructive in planning, and courageous in living, we can share responsibilities with other communities for the making of a united people $s^{\prime \prime}$ What a volte-face from their stand in 1938 for a united Burma to their disruptive activities and demand for a sovereign Independent Karen State outside the Union of Burma. Here again it is clear that the Karens have no consistent ideological conviction or objectives

The review would not be complete without a tribute to the loyal Karens. The total Karen population inside Burma is one and a half million, and roughly five percent of the total population was estimated to be directly involved in the insurrections with the rest remaining loyal.

\section{The Karens' Point of View}

In order to grasp the significance of the present dire state of affairs in Burma it is necessary to look into the historical background of the people of the countrys For the events of the country have moulded their character and outlook and influenced their actions in this present era.

Present strife between the Burmese Government and the Karens is very deepseated. It is only the climax to a long historical struggle between two peoples of 
two different migrations into Burma. These two peoples are different in all the important aspects which help to engrain solidarity and unity, different in race, languages religion and tradition. Never have a people been more influenced by the tradition than the Karens.

The first migration into Burma, as agreed by authentic historians such as Professor Harvey and Pearn of London, was probably that of the Karens sometime in the early centuries of this era. They were followed in turn by the Mons and Shans or Tai, all people of this Eastern migration with their whole background in religion, language and culture pointing to their original home in Western China, the upper reaches of the great rivers of China and Yunnan earlier known as NanChao. Nan which is south and Chao which is Prince: the Province of the South Prince. Thus to this day Sao, of the Shanss and Saw of the Karens are various forms of the "Chao" of olden times. These migrations followed the river valley gap routes of Burma's Eastern mountains, down into the warm rich valleys of the South. Karen tradition and folk-lore bear out this fact of their early and first migration into Burma.

The second migrationss much later about 400-500 ADs were those of IndoTibeto mixed tribes who came down into India along the Brahmaputra Valley and then eastward through the western mountain gap routes into the valleys of Upper Burma. These came as a mixed race imbibed with borrowed traditions, language, culture and religion, all pointing to their contact with the strong influence of Hindu civilization.

From the very earliest meeting of the people of these strongly opposite races, there ensued a long bloody struggle for supremacy which nearly came to the people of Eastern migration when the Shan Kingdom held sway over all Burma, even into Assam, from about 1200 to $1480 \mathrm{AD}$. From thence and onward to modern times, the scales of the balance have swung back and forths with one side gaining temporary ascendency over the other and vice-versa right up to the time of the last stage of the annexation of Burma by the British in 1886. Prior to this date Burma had never witnessed a single all-powerful central authority, bearing rule over the whole country; even at the height of the most enlightened Burmese monarchial dynasty, it was only in Upper Burma around Ava and Mandalay that sway was held. Burma's history is one long record of anarchy and bloodshed between their own contenders for power and against the people of the Eastern hills and Arakanese of Arakan, who even to this day do not consider themselves a part of Burma.

The period of Anglo-Burmese war and the British administration.

(a) 1824 (b) $1854-56$ (c) 1886-1942 (d) 1945-47.

In very brief and broad outline, this comparatively short historical periods was yet of great importance as a period of respite from bloodshed in B ritishoccupied areas, and thus a time of progress and development, specially after 1886, under the all-Burma administration of the centralised authority of the B ritish crowns At this juncture the importance of background should be noted, for it weighs heavily on the present position of the Karens and their relation towards their Burmese neighbours, and vice-versa. It is a fact that Burma was annexed by the $B$ ritish in three stages and in three different territories, one area at a times

1824. The first areas occupied by the B ritish at the close of the first AngloBurmese war were the Arakan and Tenasserim areas, viz., Salween, Moulmein, Tavoy, Mergui territory in 1824. This latter region was a predominantly KarenMon area. The Burmese proper never actually moved down in mass into Lower 
Burma and the delta of Irrawaddy till much latern at the time of the 2nd and 3rd annexations. From this early period the British used the Karens in their wars against the Burmesen and the Christian missionsn the American Baptist Missionn had already been established in the area twelve years prior to the territory becoming British. The point is important.

To the Karen mind as given by their traditionn the coming of the missionaries and the British was nothing but a fulfilment of their long cherished hopes and expectations of the "Young White Brothers'h return to give them succour from oppression.

To the Burmese the coming of the Christian missionn followed soon by the British gunsn was that of a foreign foen detested from earliest contact. The Burmese lived in a world by themselves without any idea of the outside world. To them Avan Amarapura and Mandalay were the centre of universe. This unfortunate Burmese resentment towards the foreigners and the Karens was only aggravated as time went onn when hundreds and thousands of Karens embraced the faith of Christianity and made rapid progress in education and national consciousness, even before the fall of the B urmese kingdom in the north. Prior to the coming of the missionaries and the Britishn the Karens' only experience was of one long struggle of warfare and, when captured in battlen of Burmese slavery . Hence Karens remained in the fastness of the eastern mountain areas till they saw the coming of the missionary and the British. To the Karensn the appearance of the missionary and the British Government meant law and order and cessation from warfaren thus progress.

1854-56: The second Anglo-Burmese War. By the time of the second AngloBurmese War in 1854, the Karens of the Tenasserim, areas were well on the road to progress in having their village schools and churches. They had advanced much in modern learning and speaking the English tongue. This was a point of very sore anger to the Burmesen for it is recorded that the Viceroy in the then mat and wooden Rangoon passed an edict thatn if any Karen in Burmese territory was found to have learnt the art of reading and writingn the penalty was death by crucifixion. The period 1824-1854 between the first and second Anglo-Burmese wars was one of great persecution for the early Karen churches. Many suffered martyrdom by burning and crucifixionn even in the vicinity of Rangoon. But this only spread the flame of Christianity throughout the delta west of Rangoonn then mostly populated by Karens and Talaings; even to this day the Burmese are found mainly concentrated in riverine towns while the Karens live and work the vast paddy fields in the delta districts.

The close of the second Anglo-Burmese war of 1854 brought the seat of the British Government to Rangoon, with Toungoo, a strong Karen Centre, as the British-Burmese Frontier town. Again in this British and Burmese struggle the Karens were used as levies to fight the Burmese.

1854-1886: contrast Burmese unrest--Karen progress. This was a period marked by great unrest and strife in the Burmese Kingdom of Upper Burma. It was in this period that vast thousands of Burmese fled from their Kingdom and entered British Burma for refuge and safety. Harvey recorded that just prior to the outbreak of the third Anglo-Burmese war (1886) over one quarter of a million Burmese within the space of a few months crossed over the Toungoo border into British Burma.

Howevern in contrast to this condition of the Burmesen during the same period the Karens had made rapid advances. Their church organization had grown to 
such an extent that their Bibles, hymn books and other educational text books appeared in prints The preface to their present hymn book [Sgaw Karen Hymual, 1922 edition] is a commentary of the timess It reads: "In 1867 a committee consisting of Revs. B. C. Thomas, J. B. Vinton, and C. H. Carpenter, was requested by their fellow Karen Missionaries to prepare a new edition of the Sgaw Karen Hymn Book.s' By 1875 they had established their High School in Rangoon which later became Judson College, and earlier still in Moulmein they had founded schools throughout B ritish territory in Tenasserim, in the delta of Irrawaddy region in Toungoo. Their schools and churches had sprung up by the scores. Toungoo, Basseins Henzada ands of courses Moulmein had developed into strong Karen cultural centres. Already some Karens had been sent abroad by the American Baptist Mission Board and had returned with advance educational degreess The late T. Than Bya, D.D.M.A. was the first in all Burma to have earned a degree abroad. At this period the Burmese Kingdom was still in existence in the North. The Karens were politically conscious of their national status, as proved by their legal registration and founding of their political organization of the Karen National Association formed to safeguard their national interest with branches all over British occupied Burmas This was five years before the Burmese Kingdom fell. In the armed services of the Crowns Karens had already proved their value and also held responsible positions of trust in the Police Force.

British Policy Reaction. But even by the close of the 19 th century it was evident that British policy towards minority people led by the Karens was one which deepened the natural rift between the Karens and the Burmese. The policy seemed to follow a course by which the Karens' traditional loyalty was used in time of strife between the British and Burmese and thens when time returned to normalcy, Karens were given the scraps in an endeavour to appease the Burmese. This policy, and the rapid advancement of the Karens under the American Christian Mission, only inflamed the already existing bitter antagonism and disdain with which the proud Burmese had looked down upon their once down-trodden Karen foe and captive slave. Now the Burmese were forced to witness and accept the Karens on a footing of equality and they found that, if anything, they were more advanced in ways of modernism than themselves.

The policy of diplomatic appeasement followed by the British Government after any period of strifes to the extent that friend was sacrificed for foe right up to the time they vacated Burmas only aggravated the already delicate position between the Burmese and the Karens. It seemed clear that the problem was evident even at the close of the century as evidenced by Donald Smeaton's book "The Loyal Karens of Burma.s' He was a high civil servant of the Crown who had served in Burma. His inclusion of extracts from letters of the Revd. J. D. Vinton to the British Government on behalf of the Karens referring to the problem which seemed ripe even then would make very parallel reading today. And yet those who should have known with all this light assert that the Burmese-Karen problem is a new creation of post World War II, agitated by crankish Karen sympathizers. In fact the scene has never faded. Progressively stage by stage the Karens have pressed for a solution which would end this perpetual tension.

In $1922 \mathrm{~s}$ the Karens strongly pressed their political case before the British seat of Government at Delhis Indias and also before the well-known Whyte Committee chaired by Sir Frederick Whytes The Whyte Committee was formed as a result of the first political agitation by the Burmese for greater representation in control of the country. In 1928sthesKarensKnightsDr. Sir SansC. Po, Kt. M.D. (U.S.A.) took the cause of his people to London where he left a record in his pleading for a Karen State in his book "Burma and the Karens, $\mathbf{s}$ " published in 
London. By the early part of the new century of 1900 , the Karens had already designed their own drum flag which they still honour today.

The period between 1939-42. It is sufficient to note in passing about this period, that by the opening event of the close of this period i.e. 1941-42 KarenBurmese relations had deteriorated to such an extent as to make the breach almost irreconcilable. The tragic slaughter of 1942 after the British withdrawal from Burma and the incoming of the Japanese sealed the question of any amicable settlement. The utter savagery of massacres suffered by the Karens when overpowered by the new Jap-sponsored Independence Army under the command of Major General Aung San scarred and scared forever Karen thought and sentiment towards the Burmese.

The period of World War II again witnessed outstanding service of heroism and loyalty to the Allied cause, of liberation from the world menace of Fascismn The Karens rendered outstanding service along with their cousin hill people of the Eastern group, Chins and Kachins. To submit and collaborate with the enemy would have at least brought respite from bitter suffering of torture, but the character of the Karens is such that death is preferred to betrayal. If this deep rooted sentiment of Karen psychology could have only been grasped and appreciated by those directing the new phases of Burma's destiny much advantage would have been gained in building the new Independent Burma. But the same old policy of the deaf ear and the blind eye took the place of stark reality. Wishful hopes replaced hard work towards a true settlement. Hence the deluge in all its cruel garishness led to the disintegration of the whole country today. Instead of reconstruction there is re-destruction on a frightening scale. In the place of rehabilitation there is dispopulation of lovely people of all races, Burmese, Karens, Kachins, Chins, Shans in all-out many-sided bloody strife. For this ghastly tragedy much blood lies heavy on the British hands. During the period 1945-46 far-sighted Karen elders under the mass elected leadership of Saw Ba U Gyi, Bar-at-Law, sensed the present danger now being sadly witnessed.

The internal events of 1945-46 in the country gave strong indications of what was to follown Thus, urged by a sense of grave responsibility and sponsored by the mites of hundreds and thousands of Karen offerings for the purpose, a Karen Goodwill Delegation, which included Saw Ba U Gyi, went to London. In late 1946 and almost in prophetic insight it placed before the British Government their anxieties for the future if their vital problem was left unsettled. They returned to Burma bitterly disappointed. British diplomatic policy was recast in the same old mould and, like Nelson's proud example, turned the blind eye on the stark fact presented. The Karens approached both the Burmese and the British to beg for a careful consideration of their case, but without avail. Speed and rapidity was the new order of the day in dealing with long outstanding issues. It must be clearly noted that the questions of Burma's right to Independence was never at any time questioned by either the Karens or those true friends of Burma. All that was pleaded for was that all the people of Burma of all shades of opinion be given the chance of free expression in the choice of their leaders to voice their destiny and bring together their truly representative leaders to work out a way to settle the many unsolved problems in handn including that of the minorities. Even by mid-1947 a large section of the country in central Burma had already gone underground in a Communist influenced rebellion, the first to start of the many-sided rebellions against the British maintained Government in Rangoon.

The psychology of Burmese individualism and unrestraint was not grasped; wishful hopes that all would be well could not alter the reality of the actual condition of tension not only of the Burmese versus Karens, but of Burmese versus Burmese factions jockeying for power as of the days of Thibaw's Kingdom. 
In 1948, Independence was barely a month old when events began to gather momentum. By mid-year personnel recruited from political private armies for the newly formed Burma Regts accelerated events as they, in parts and also whole battalionsn deserted from the new government's command to their respective political leadersn a process which has continued to the present (1957). Only the minority regular British tram [sic] time troops, Karens, Chins, Kachins and Burma Gurkhas stood at their posts of duty under the new government, and in July of the year 1948 actually saved Rangoon from falling into the hands of the Communists and deserters who closed in on the cityn The Karen elders and leaders were hopeful that this demonstration of good will, of not taking advantage of weaknessn would convince the new government and the Burmese leadership of the Karens' genuine desire for goodwill and peacen The demonstration of loyalty to duty was in spite of violent anti-Karen B urmese press attacks on the question of the Karen agitation for their staten Karen hopes were in vain. The Burmese government interpreted Karenn Chinn Kachin solidarity and discipline as a danger signn The Burmese deserters were taken back into the fold of the armyn whilst there then began a systematic policy of disarming the Karen levy forces who were standing by their villages to avert danger which had already begun to take shape. Simultaneouslynwith the endeavour to disarm the Karens, the Burmese Government formed new Burmese irregular levies designed to reach a strength of fifty battalionsn Memories live long in the East and in the Karen mindn They had very vivid memories of the attitudes and discipline of the irregular Burmese levies which since 1941 took on various names such as the B.I.A. (Burmese Independence Army) B.D.An (Burmese Defense Army) etc.

When the Karens witnessed the formation of these multi-colour groupsn they then organized their KNDO which were later taken into the "Kawthulay" armed forces under the Kawthulay central command of the war office and army general headquartersn

The Burmese Government accelerated events in the creation of a new armed force now termed B.T.F. (Burma Territorial Force) and attempts at disarming Karen Armed irregulars. Karen regulars were dispersed for a part throughout Burma away from their home areasn The straw indicates the wind. Karen suspicion was aroused. Subsequent events confirmed their suspicionn By AugustSeptember of the year began a series of arrests of elder Karen and Mon leaders in Thaton and Moulmeinn The arrest of their leaders in late August brought on the first open clash between the Burmese Government and the Karensn On the arrest of elders in Thatonn the Karen Armed Police moved in and took Thaton and Moulmein without bloodshed law and order were maintainedn They decided not to be caught unprepared again as in 1942. This should have been warning enough to the Burmese Government that a terrible storm was gathering and would soon break if statemanship did not take the place of party politicsn Party upon party withdrew its support of the unpopular government and thus began a many-sided civil war.

But the climax had not been reachedn In spite of all that had happened Karen leadership went the second mile to leave no stone to the settlement unturnedn At this point great credit and honour should have been the lot of Karen leaders when they responded to the pleading of the Burmese Government to return Moulmein with the promise that the question of Karen State would be given first priorityn The British press also gave prominence to the forming of the Karen State Committee in October 1948 under the able leadership of Chief Justice of Burma Sir Ba U, B.L. [Bar-at-Law]. Under their elders' instruction the Karen Armed Forces reluctantly handed over Moulmeinn Saw Ba U Gyi took the word of the Prime Minister Thakin $\mathrm{Nu}$ that the Karen case would receive constitutional considerationn $\mathrm{By}$ 
early December Sir Ba U's Committee agreed, in principle, that the Karens should have their state, but within the Union of Burma. This was about 16 th December, hardly a week before the tragic events of a horrid massacre were to cast the mould and strike the spark which set ablaze the Karens into action for an all-out struggle. Just prior to the publication of the finding of the said Committee there commenced a wholesale widespread campaign of disarming Karen villagerss in spite of the conditions of anarchy in the whole country with civil war in full blast of Burmese versus Burmese. The spark was struck in the beautiful large Karen village of Palaw in the Tenasserim areas between Tavoy and Mergui with its fine church and own middle schools a model village. Government Armed Burmese Police accompanied by a Karen officer of long standing entered the village and presented the Government's request for elders to hand over all arms.

Assurances were given supported by the Karen Officer. This was 24 th December 1948, X'mas eve. The Karen elders conceded. Arms were handed over in the interest of peace and understanding. The Burmese Police party was invited to attend the carol celebration of the night and partake of the usual X'mas eve refreshments. They did attend. The village assembled in the church before midnight to bring in the Christmas with bells and worship. The carol parties had met in the church after their rounds. Worship was begun. Suddenly the explosion of grenades thrown into the church by the Burmese Police who had surrounded the church disturbed the worship. Those who did not die in the church were mown down by automatic fire as they fled the church. Already other parties of the police set ablaze the village homes and schools. Most conservative estimates give the death roll in the church as over 300 (a Singapore despatch).

Evil tidings travelled on swift wings. Karens everywheres stung to the heart by this outrage, took this act as the last straw. The Burmese Prime Minister himself flew down to the scene of tragedy with Karen elderss but on his return to Rangoon he announced the incident was "a mistake on the part of the police $s$ " This added insult to the injury. But still almost incredible, Saw Ba U Gyi at the risk of losing his leadership with his people pleaded for patience and forbearance as reported by his broadcast over the Rangoon radio for restraint and patience. But alass the last day of the first month of the New Year 1949 brought the last senseless act of brutality which set the Karens in open warfare with the Burmese Government. On the 31st January, 1949, in Rangoon the capital city, again orders reached the elders of the Karen section of the city (Ahlone Karen Quarters) to give up illegal arms. After a peaceful search by regular Chin troops, seven arms were found, five shot-guns licensed, two Army rifles unlicensed. The day passed off peacefully but not the night. Soon after midnight of the 31sts B urmese troops surrounded the Karen Quarters and awoke the sleepers with mortar and machinegun fire. At the same time scores of houses were set ablaze. This slaughter of unarmed women and children continued for over two hours. By daylight a large portion of this Karen Quarter was reduced to ashes. Survivers were herded into the so-called refugee camp for safety and behind the barbed wires. Meanwhiles at about 0700 hours on 31st January 1949 a long series of incidents taking place at the Karen Quarters at Thamaing were reaching their climax. A young Karen serviceman was returning to his work at Mingaladon after his night at his village with his people. The Burmese soldier who was patrolling the Thamaing area shouted to him from across the main road not to leave the place. As the young man proceeded to get into the bus the patrol man fired three shots as the bus moved away. Evidently these three shots were a signal for a general attack on Thamaing Karen Quarters, because these three shots were immediately followed by a full blast of mortar, machine-gun and rifle fire from the main detachment of the Burmese Government troops stationed not 300 yards away. An all-out attack 
on Thamaing Karen Quarters was ons and thus began the full-scale war that has been going on ever since between the Karens and the Burmese Government. Armoured cars, tanks, aircraft, motors and guns, in fact all the military might of the Burmese Government, came into play. These Burmese troops had been stationed there for some weeks before the incident on 31st January 1949 and had intermittently shelled and fired into the Karen Quarters at night. There wass however, no retaliation on the part of the Karens on any one occasion.

By noon of that fateful day, units of the regular Karen Army had come to the rescue of their kith and kin at Thamaing. This outrage spread to Insein, only ten miles from the General Headquarters of the Burmese Government, and less than two miles away from their air base; it became the "Tobruk" of the Karens with only a few hundred armed men. Insein was held and then given up--not surrendered, and evacuated by all armed forces when it became evident that supplies would not last. This small force marched hundreds of miles to join their main bases and headquarters at Toungoo in the North and their delta headquarters in the West. Most fortunately the Karen leadership had made it clear and plain that they were not fighting the Burmese people but the Burmese Government who had lost their respect and confidence with their deeds of shame.

Thus were Karen administered areas which included large Burmese populations placed in a position of peace and cooperation. In their drive North the Karen troops captured the Burmese operational document named "Operation Aung San" which clearly indicated the intention of the Burmese Government to eliminate the Karens first, then other hill people. This was neither the solution of the problem. But the Karens have their own solution of the problem. They were not to lay their necks down for the slaughter, nor their women to dishonour.

\section{Insein}

Readers who knew Burma and especially the Rangoon and Insein areas would no doubt like to know the actual facts about Insein. It was in the limelight of the Karen rising. The following are statements given by Saw Bellays a retired Karen Customs Officer, who was present throughout the incidents that took place there. He was asked by the Burmese Government to give an explanation as to why he should not be charged and prosecuted as one of the rebels. The writer can really vouch that his statements are facts and unbiased to any side, as the writer himself was in the know of all important facts mentioned by him in his explanation to the Government of Burma.

He said: "The Karen National Defense Organization (K.N.D.O.) was organized some time about February 1946 with youthful leaders like Mahn Ba Zans Saw Hunter Tha Mwes Saw Sankey and others. The sole purpose of the organization was to defend and safeguard the lives and properties of the Karens in general against lawless elements and criminal acts. The Karens in general had suffered at the hands of the Japanese and the Burma Independence Army during the war, especially in Myaungmya and Papun districts. The formation of K.N.D.O. was considered essential for the future welfare of the Karens as conditions prevailing in the country were never too peaceful; that was the aim and purpose for which the K.N.D.O. was formed.

"The K.N.D.O. however remained inactive and the organization more or less existed on paper with some skeleton branches all over the Karen areas. It was only after the attainment of Independence in $1948 \mathrm{~s}$ followed a few months later by the Communist uprising throughout Burma, that the activities of the K.N.D.O. were revived. It was then realised that the K.N.D.O. as a defence organization 
should function to safeguard Karen villages against Communist insurgents. Not only was it necessary to defend and safeguard Karen villages but it was also found essential that the Karens in general should be protected against Communist influence and intimidation. It was only at this period that the K.N.D.O. was organized more or less on proper lines as a defence organization.

"In the Insein district, where Karen villages are isolated from one anothers it was necessary to arrange for members of the K.N.D.O. from other districts like Thaton and the delta to supplement the numbers required for active defence measures. Maung Maung Than took up the job of the area commander for Insein district with his headquarters at Insein town. Similar arrangements were made in other districts for the Karens in general.

"It was only because of this arrangement that the Communists withheld their influence and attacks on the Karens as a whole. The policy of the K SN.D.O. then was strict neutrality, iæ. they would only defend Karen villages without helping the Government in any way as by so doing the possibility of communal clash between Karens and Burmese might take place. The Communist party which rose against the Government was composed mainly of Burmese members. The Communist insurrection however began to gather momentum with mass desertion and mutiny by some Burmese Armed Forces. By August 1948 most of the Police Stations in Insein district were withdrawn as it was found that there were not enough Government Armed Forces to protect them.

"At this stage the Prime Minister Thakin Nu and Saw Ba U Gyi, President of the K.N.U. (Karen National Union) came to some understanding regarding the Karens' claim for a separate state. An enquiry commission was formed with Sir $\mathrm{Ba} U$ as Chairman and members like Saw Ba U Gyi, Mahn James Tun Aung and Saw Tha Din of K.N.U. Meanwhile Insein and Rangoon itself were in danger of being seized by the Communist insurgents. Many Police Stations fell into their hands. The Police and military found it hard to cope with the situation.

"Having come to some understanding with Prime Minister Thakin $\mathrm{Nu}$, Saw $\mathrm{Ba}$ U Gyi did his best, and tried to influence the K.N.D.O. to help the Government especially in the Insein and Twante areas, and for the K.N.D.O. so employed to come directly under the command of General Smith-Dun who was then the Supreme Commander. The K.N.D.O. in Insein were allotted areas like Hlegu, Taukkyan and Hlawga for defence and garrisoning duties. This arrangement enabled the regular forces to strike at the Communists. The K sN.D.O., who were thus employed, with whatever arms they possessed, were allowed to move freely in Insein district with their arms within their area of duty. In Twante the same arrangement was made. In the case of Twante arms and ammunition were even supplied to them after they wrested the town from the Communist hands with their own resources.

"Meanwhile the Burmese Press, not knowing exactly what arrangement the Defence Department had with the K.N.D.sO. of Insein and Twante, came out with startling news about the K SN.D.O. plan to seize and gain power in order to fulfil a demand for the Karen State. Many wild rumours and stories against the K.N.D.O. and the Karens in general appeared almost daily in Burmese newspapers. Stories like foreign planes flying over Karen areas and dropping mysterious cargoes appeared in papers.

"The Government however would not declare openly what policy or attitude it was adopting towards the K.N.D.O. Whether the Burmese Press or some private information against the K.N.D.O. was responsible for the Government's change of attitude to the K.N.D.O. was hard to say; the K.N.D.O. suddenly found 
themselves no more required to provide any of the active help which they had rendered during those critical days for the Government. Meanwhile levies or Sitwundans were formed as an auxiliary force to help the Army. These units were supposed to be an auxiliary to the Army and yet it was never under the control and at the disposal of the Supreme Commander.

"By this time, it was found necessary to close the K.N.D.O. in Insein. They were therefore regrouped in Insein which was their headquarters. Their members could not have been more than 200 to 250 men. The $B$ urmese again went on publishing in bold headlines that the K.N.D.O. were massing in great numbers to attack Insein and Rangoon. Reports against criminal acts by the K.N.D.O. in Insein were recounted in Burmese papers. The Burmese Government and the Burmese community in Insein were advised against probable attacks by the K.N.D.O. Consequently the Burmese community in Insein were armed to defend themselves against the K $\mathbf{S N} . \mathrm{D} . \mathrm{O} s$ Units of Burmeseslevies were posted in Insein town to cope with the possibility of a $\mathrm{K} \mathrm{SN} \mathrm{SDSO}$. attack.

"It was to avoid any possible clash between the K.N.D.O. and Sitwundans or levies in Insein that Saw Ba U Gyi and I with Brigadier Ne Win, then Deputy Supreme Commander, U Kyaw Myint, Commissioner of Police, U Ba Mg, I.G.P. and some other members met in the office of $\mathrm{U}$ Ka Si to discuss ways and means to repatriate the K.N.D.O. in Insein back to their respective villages and districts. It was decided at the meeting that a sub-committee was to be formed at

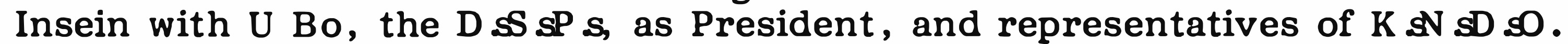
levies and other representatives from the Burmese community. The sub-committee was to meet every morning and to submit its decisions and recommendations to the Committee sitting in Rangoon. During this time many incidents took place to aggravate the situation between the K.N.D.O. and the levies.

"I never kept a diary of these incidents, but as far as I can remember the following incidents took place before the clash came about. On the eve of the Karen New Year which fell on the 29th December 1948 I went to the New Year's eve party given by General Smith Dun at his residence at Mingaladon. That night all the villagers and K.N.D.O. in Insein were strictly ordered, according to the decision of the meeting arrived at by the Karen elders of Inseins not to celebrate the Karen New Year's eve by firing shots on the New Year as was usually done in the past as, by so doing, unnecessary alarm and commotion might be caused to the people of Insein. Church bells would be rung and midnight service would be conducted instead. I myself heard the order given to the K.N.D.O. by their Commander, Maung Maung Than. It was about $12: 15$ or $12: 30 \mathrm{a} . \mathrm{m}$. that night that I arrived at home in Taungthugon after the completion of General Smith-Dun's party. No sooner did I get into bed when I heard the reports of rifle fire coming from the direction of the D.C.'s bungalow followed by a long burst of rifle and automatic gun fire. The firing went on and spread all over Insein town. Most of the bullets came into the Karen Quarters. Some stray bullets came close to my house, and I and my family went downstairs to sleep in order to avoid being hurt by one of the stray bullets. That night one mortar shell fell in the Karen Quarters. Fortunately, no one was injured. Again on the 22nd of January 1949 at about 8:00 or 9:00 p \$n. one armoured car passed along the Civil Station road in the direction of the Police Station, fired a long burst of bren gun into the Karen Quarters as it went past. The following morning most probably the same armoured car passed along the same road but in the opposite direction firing another long burst into the Karen Quarters; this time abuses were also hurled at the Karens by the crew of the vehicle.

"The Thamaing Karen Quarters during this period also experienced the same trouble from the Burmese levies or Sitwundans who were patrolling the road at 
night. Shots were fired at random into the Karen Quarters on several occasions by these levies, including mortar shells, one of which fell into Saw Benson's compound causing serious injury to one Mrs. Simon.

"These incidents certainly did not mean well for helping to restore peace and order in Insein. The Committee and sub-committee sat in Rangoon and Insein respectively to bring about a peaceful solution to the situation. In Insein under the control of a Police Inspector, 4 K.N.D.O.s, 4 Police and 4 Burmese levies made a joint patrol along Sawbwagyigon road in the Insein area.

"The situation however remained unsatisfactory. It was at this juncture that General Smith Dun, in order to avoid the clash, went to the Prime Minister who was also Defence Minister, Thakin $\mathrm{Nu}$, to request him to meet Saw $\mathrm{Ba} U$ Gyi and clarify once and for all the position of the K.N.D.O. Accordingly, Thakin Nu fixed 31st January 1949 at 12 noon to meet Saw Ba U Gyi who was to be accompanied by me. So we made necessary preparations to meet him at the appointed date and hour.

"What happened however was that on the 31st January 1949 morning at about $6: 30 \mathrm{asm}$. shots were heard from the direction of Thamaing Karen Quarters which grew in intensity and became continuous. Soon came to us reports that Thamaing Karen Quarters was being attacked and surrounded by the Burmese levies. Saw J. Poo Nyo, a retired Frontier Service Officer who was then the Karen Affairs Officer, who lived in that quarter, 'phoned up General Smith Dun telling him about the attack. General replied that he would 'phone up the Prime Minister Thakin $\mathrm{Nu}$ to intervene as he himself did not know who was responsible and who had given the order for it. In the meantime the attack continued. The K.N.D.O. were very much outnumbered and were soon outfired by the levies who almost entered the Karen Quarters. Suddenly in the nick of time some Karen armed personnel arrived on the scene to save the situation. They came to the rescue with the belief that the unprovoked attack on the Karens by the ill-disciplined levies was made without proper authority from the Government. The fight continued the whole day with the K.N.D.O. defending their quarters. Meanwhile in Insein town many levy units were placed all over the town especially around Taungthugon Karen Quarters. They however did not start the attack till the morning of 1st February 1949.

"The proposed meeting between Saw Ba U Gyi and Thakin Nu could not take place owing to the attack on Thamaing Karen Quarters, as by that time movement of vehicles between Rangoon and Insein had been cut offs I learned later that General Smith Dun's request had fallen on deaf ears.

"It must be noted that during the sub-committee's meeting at Insein one question was put up to the Main Committee at Rangoon regarding the fire arms carried by the K.N.D.O., whether, if they were repatriated, their arms should be surrendered or not. The decision made by the Main Committee was that the surrender of arms by the K.N.D.O. did not arise for the time being.

"It must also be noted that the joint patrol of the K.N.D.O., Civil Police and Burmese levies endeavoured to function up to the last day before Thamaing Karen Quarters were attacked.

"In my opinion, if the Government found the K.N.D.O. too troublesome for the sake of peace in Insein or anywhere, it should have allowed women and children in Thamaing and Insein to move out to a safe place, with the Government servants who were not involved in the activities of the K.N.D.O., before any attack was allowed to be made. As it was, the wholesale, surprise attacks not only on Thamaing and Insein, but also in Ahlone, Rangoon did not comply with justice and 
fair play. It was also to be noted that only 4 days after the attack by the levies Rangoon radio denounced the K.N.D.O. as an illegal organization and so did the newspapers of Rangoon. If Saw B a U Gyi had been allowed to meet Thakin Nu on the day fixed through the effort of General Smith Dun, the present trouble would not have taken place. The Karen Armed Forces which came to resist the attack on Thamaing Karen Quarters were after all human beings who could not hear or bear any ill-treatment or injury befalling their own kith and kin if the levies had overrun the place. They had before heard of the fate of the Karens in Tavoy and Mergui under the leviess

"In my case, knowing full well my responsibility as an elder of my community, I did everything that I considered justifiable for the safety and security of the people in general and the Karens in particular except taking up arms and fighting in front with the K.N.D.O.S.S'

Saw Po Tu a senior Karen Police Officer was also caught in Insein by the Burmese-Karen troubles and went through the ordeal unto the end, and was asked to explain why he should not be charged and persecuted as one of the K.N.D.O.S. The writer knew him well and considers that his statements are true and unbiased. Hence his statements are included in this book to give a more clear picture of the "Insein Incident" to those who are familiar with and lovers of Burma.

He said:

"To the best of my knowledge and recollection a reconciliation committee consisting of the following members was formed in Rangoon round about January 1949 with a view to settle the misunderstanding between the levies and K.N.D.O. and the repatriation of the K.N.D.O. of Insein town to their respective homes.

"(1) Bo Ne Win, Deputy Supreme Commander

(2) U Ba Maung, T.D.M. Inspector-General of Police

(3) U Ka Si, Chief Secretary of Home Department

(4) U Kyaw Myint, Commissioner of Police

(5) Saw Ba U Gyi, K.N.D.O. leader

(6) Saw Tha H to

(7) Saw Bellay, Karen elder

"The above-mentioned committees if the information I received is correct, passed the resolution to form a sub-committee at Insein in the advisory capacity. The sub-committee consisted of the following members:

"(1) U Bo. D.S.P. Insein (President)

(2) Lt/Col. Bo A ye of U.M.P. Rangoon

(3) U Tun Ohn, D.I.G. Police Southern Range

(4) Saw Po Tu, A.D.I.G. Police, Railway and C.I.D. Burma

(5) Mahn Ye Lun, Karen elder, Thamaing.

(6) Saw Ba Than, Karen elder

(7) Saw Bellay, Karen elder

(8) Maung Maung Than, K.N.D.O. leader

(9) U Ko Ko, Burma Railway and Defence leader, Insein

(10) Two Town defence of Insein (all Burmese leaders)

(11) Two Thamaing town defence leaders (all Burmese)

(12) Major Khin Maung Myint (Burmese), Officer in-charge of levies

(13) Bo Tin Maung, A.D.S.P. attached to levies (Burmese)

"About the last week of August 1948 when the whole of Insein district was about to be captured by the Communists the white P.V.O. and Burmese Army 
deserters, the Police Station personnel of Po Aung, Tawlate, Taikkyi, Tantabin, Yet-thit and Hmawbi were withdrawn to Insein headquarters. Due to the insurgents' pressure the K.N.D.O. troops of Insein took up their position to guard the front line at Hlawga, Taukkyan, Hlegu and I am told according to the previous understanding arrived at between the K.N.D.O. and Army leaders, that K.N.D.O. was to garrison those places mentioned above to give opportunity to Government forces against the advancing Communist insurgents. This meeting was held in the office of the Deputy Commissioner, Insein and the Chairman was Bo Sein Hman and others who attended the meeting were:

"(1) Brigadier U Aung Thein, D.S.O. S.B. Sub-District Commander

(2) U Bo, D.S.P. Insein

(3) Saw Po Tu, A.D.I.G. Rly. and C.I.D. Insein

(4) U Hla Tin, Deputy Commissioner, Insein

(5) Maung Maung Than, K.N.D.O. leader, Insein and some Army and Civil Government officers.

"During the months of October and November 1948, there were reports against the K.N.D.O.s for high-handedness against the Burmese community and a few cases of dacoity, robbery. All reports were investigated by Insein Police but without success.

"Sometime in December 1948 about one platoon of levies was posted at Insein Police Station. One night at about ten or eleven o'clock, rifles and automatic fire were heard continuously for two or three minutes from that direction and at the same time I heard a few shots hitting bamboo, near by house. The following morning I went to Insein Police Station to enquire about the incident. I met the C.I.P. Insein who informed me that the shooting was done by the levies who told him that on seeing some dark figures they opened fire with both rifles andsautomatic weapons.

"The same afternoon I sent for and interviewed U Bo, the D.S.P. Insein and asked for his advice as to what action should be taken to prevent the levies from causing alarm and displeasure to the Karens, as I had on two or three occasions got reports by some Karens that they had been abused by the levies as they passed in front of their post. U Bo told me that he would refer the matter to the A.D.S.P. Khin Maung Myint, who was the Officer in-charge for the levies in Insein district, and that in consultation with him he would try his best to prevent the friction between the levies and K.N.D.O.

"The same evening the levies vacated the P.S. and took up their post at the Office of District Council, Insein which is 300 yards south of Taungthugon and Nanthagon Karen Quarters. Two-three days later at 8:00 p.m. a similar incident occurred, in the course of which rifle bullets hit the Karen village again. I reported this matter to the D.S.P. U Bo, the next day. A few days later the levies were sent back to their headquarters Singu.

"On the morning of 29th December 1948, due to unsettled conditions, the Karen elders warned the Karen public not to fire shots from fire arms on that night, despite the customary celebration on Karen New Year's eve, to avoid causing alarm to the public of Insein town area. As an alternative, it was decided to only ring the bells at $12 \mathrm{~s} 00$ midnight when the villagers should congregate in the church and honour the new year by singing hymns and in silent prayers. At 12:00 midnight church bells were rung, adults and children alike came to the church and at about 12:30 whilst the congregation was in silent prayers, firing of rifles and automatic weapons was heard from the direction of the Technical Institute, Insein, followed immediately by two mortar shells, one of which dropped in Karen Quarters. 
The prayer had to be stopped as firing was also heard from Insein town area, particularly from the direction of Insein railway quarters and bazaar. There was then confusion in the village as the firing increased.

"It was then thought that the Communist insurgents were attacking Insein town and Karen Quarters, as many shots came into Karen village. The fire lasted about 20 minutes. The next morning I went to the Police Station, but no one could tell me the definite cause of the previous night's firing except to confirm that shots were first heard from the direction of the Technical Institute, then the railway quarters and bazaar area etc. On further enquiry I learned that seven town defence unitss each consisting of 25 men, had been formed in the railway quarters and bazaar areas from the Burmese public. In one of the Burmese newspapers either in the second or third week of January 1949, mention was made that as many as 2,000 fire arms had been issued to the defence units of Insein to meet all emergencies.

"About the last week of January 1949, Saw Shwe Gyaw, O.B.I., a retired subadar Major from Wanetchaung village, came to report to me that 15 village defence guns including some licensed ones under his care were withdrawn from him by the Burmese levies posted at his village. He requested me to take him before the D.S.P. U Bo, as he wanted to mention the fact that among the firearms withdrawn from him were some Government firearms from the Insein Police Station. The D.S.P. Insein, promised Saw Shwe Gyaw to get back all the firearms from the levies when they left his village. Two or three days later subadar Major Saw Shwe Gyaw visited me again with more complaints against the levies. He said shots had been fired into his village of the Karen section from all weapons, including mortars from the said levies. There were however no casualties, but some houses were hit and one mortar shell caused some damage to his own house.

"He requested the D.S.P. to take necessary action to avoid the levies molesting the Karen villagers. In this connection, he saids Karen lady travellers were subjected to searches by the levies at the station while travellers of other nationalities were allowed to proceed without being searched.

"The second week of January 1949 was an anxious time for the civilians of all nationalities residing in Insein, Gyogon and Thamaing because of a series of unpleasant incidents caused by the levies. One night at about ten or eleven o'clock, Thamaing Karen Quarters were subject to terrific fire from all arms in possession of the levies (rifle, bren and mortar) for at least half an hour. I visited the village the next morning, and the villagers accused the Burmese levies of deliberately causing that incident for an ulterior motive or spite against them.

"At the request of the village elders a party of Gurkha troops were posted for about four days to give protection to the Karen villagers. Nothing happened during that period. They were however withdrawn without any intimation to any one.

"On one of the nights two mortar shells were fired into Saw Benson's compound causing grievous injuries to one Mrs. McSimon, an assistant of Saw Benson \& Co. I visited the scene of the crime, and the residents of that area strongly suspected that the levies that were stationed at Kaukwaing were the culprits, the camp being about a mile from Saw Benson's compound. Saw Tun Han of Thamaing was shot dead in broad daylight at Thamaing check point by the levies while returning to his village in a public passenger bus from Rangoon.

"The Karens residing along the Insein Civil Station road reported on two or three occasions to me that the levies patrolling along that road not only abused them but also threatened to exterminate them, saying 'you Karens will all be exterminated.s The Karen U.M.P. personnel of Ywama also made similar complaints. 


\begin{abstract}
"On or about 22 January 1949 at about $8 \mathrm{p} . \mathrm{m}$. , some rifle shots were heard from the direction of the D.C.'s bungalow; one hour later, an armoured car came from the same direction towards the Karen village and fired into the village. On the $23 \mathrm{rd}$, another armoured car came again and similarly fired into the Karen quarters. The next morning whilst I was talking to a police of ficer and men, two armoured cars appearedn stopped at a road junction and mounted their guns towards the Karen village of Nanthagon and Taungthugon. I went up to them and, judging from their hostile demeanour, I advised them not to do anything rash without the knowledge of higher authorities, and also told them that the Government was taking steps to clear up the position of the K.N.D.O. To substantiate my statement I showed them the minutes of the meeting of the Rangoon reconciliation committee. Bo Tin Ohn himself admitted to me that he and his men were responsible for the firing done into the Karen villages. Owing to the above unpleasant incidents, the situation between the Burmese levies and the K.N.D.O. was not a happy one.
\end{abstract}

"I went to the D.S.P., U Bo, and told him to contact the of ficer in charge of levies immediately, referring to the fact mentioned in the preceding paragraph. The levy Commander, Major Khin Maung Myint, replied that he would order his men to return to headquarters at Singu. As the situation was very critical indeed, the D.S.P., U Bo, and I and also S.D.P.O., U Kyaw, held an informal conference at which we decided to request Brigadier Aung Thein, Commander of South Burma Sub-District, to substitute neutral armed force for the levies patrolling the Karen area. The same day, Sunday, we went to interview the B rigadier who promised us a platoon of Gurkhas by $5 \mathrm{p} . \mathrm{m}$. and also advised us to request the Deputy Supreme Commander $\mathrm{B}$ rigadier $\mathrm{Bo} \mathrm{Ne}$ Win for an order for the levies not to patrol the Karen area. We traced $\mathrm{Bo} \mathrm{Ne}$ Win at $2 \mathrm{p} . \mathrm{m}$. at the race course where we explained to him the situation at Insein and the arrangements we made with $B$ rigadier Aung Thein. He gave us the written order needed. The Gurkha platoon arrived to patrol the area, and peace prevailed for the period from 23 rd January till they were withdrawn on the 30th January 1949. During the period the Insein reconciliation committee sat regularly, passing a number of resolutions, under one of which a combined force of $4 \mathrm{~K} . \mathrm{N} . \mathrm{D} . \mathrm{O} ., 4$ Civil Police, and $4 \mathrm{~B}$ urmese town guards was to patrol the area under Inspector of Police. Two important subjects were also discussed: (a) Repatriation of K.N.D.O.; (b) withdrawal of arms from them. Reference was made to Central Committee in Rangoon on these two resolutions on 27 th January 1949. A reply was received the following day to the ef fect that the question of withdrawing fire arms from the K.N.D.O. had not yet arisen.

"Mondayn 31st January 1949 at 12 noon, was the time fixed for the meeting between the K.N.D.O. leaders and Prime Minister Thakin $\mathrm{Nu}$ for a clear-cut policy of the Government on K.N.D.O. The meeting never took place due to the blocking of the road at Thamaing on account of the fight between the Karen Village defence and the Government levies early that day at about 6-30 a.m.

"According to the Thamaing villagers, the levies surrounded the village by surprise at dawn and fired into it with all their firearms including 3 mortars causing some casualties to the villagers. From now the fight continued and developed into what is called 'The Battle of Insein '; with the arrival of Karen reinforcements from time to time, the battle lasted 3 months 21 days when the K.N.D.O. vacated Insein."

The writer, a Karen himself, is loath to give any comments on this KarenBurmese trouble, as readers are bound to doubt the truth of his statements especially when in favour of the Karens. Hence he requested readers, especially those who knew Burma and are lovers of Burma, to read and consider carefully 
the views given by both Karen and Burmese on the above question (Karen-Burmese troubles). The statements given by Saw Bellay (a retired Customs Officer) and Saw Po Tu, a senior Police Officer still in the service of the Burniese Government, should not give any doubt as to their truth, as their lives hung on their explanation of the "Battle of Insein.s" 
CHAPTER 12

THE KAREN STATE

From the pen of another Karen came a pamphlets whose aim and object he said was to give the true facts about the "Karen State" in order to bring unity and satisfaction to both the Burmese and Karens. He said the Karen State is a very important matter, so if it is settled to the satisfaction of both the Karens and Burmese, Burma will progress like a rising tide; if not, it will be the reverse.

It has been stated by some Burmese newspapers that it was entirely due to the instigation of the Imperialists that Karens are asking for a State which they had not even dreamed of before. He continued to say that such an assertion is entirely wrong and that the matter had been in the minds of the Karens for a very long time.

According to their tradition and legends, they originated from their home in Mongolia and, having crossed the Gobi Desert at the River of Running Sand, they gradually pressed southward and settled down in their present locations from a very ancient time. This assertion is substantiated by their traditions carefully adduced by many writers about the Karens, whilst Burmese history clearly shows that the Burmans are descendants of King Tha-gya Thagi-win of India.

Some Karen leaders contended that, since the two races originated from different sources, contrasting in habits, customs and in nearly all their characteristics, it would be impossible to mix up the two togethers in the same way as mixing up two different kinds of rice spoils them when cooked; while others think that there is no reason why the two can not be amalgamated, since the difference between them is nothing like that of the Hindus and Muslims who could not even eat and drink from one another.

In his book "The Loyal Karens," Mr. D. M. Smeaton M.A. I.C.S. had recommended a separate state for the Karens to give them a chance to grow up as a nation in their own way. In his recommendation he cited the example of the small tree that can grow big and fast when not dominated by a bigger one.

Sir San C. Po, who was one of the most educated and dignified leaders of the Karenss had also written in his book "Burma and the Karens" that the whole of Tenasserim Division should be given to the Karens as a states where they could make rapid progress under their own administration. The Karen leaders also represented their case before the well-known Whyte Committee, chaired by Sir Frederick Whytes which was formed as a result of the first political agitation by the Burmese for greater representation in the control of the country; but the Karens met with no success. While the Karens were thus inspired the KarenBurmese clash took place in 1942, following the withdrawal of the B ritish Government. Therefore the desire for a state grew stronger than ever as a result. But nothing could be done during the Japanese occupations When the Japanese surrendered and on the return of the B ritish in 1945 some of the Karen leaders were actively engaged in their endeavour to realise their State.

In accordance with the policy under which Burma was granted Independence, it is stated that any nation which desires to be free will be allowed to be so. The 
policy of one nation ruling another, in the same way as a vulture ruling a sparrow, should be abolished. This was the prime topic which was on every one's lips at that time. Nearly all Burmese papers carried such prominent headlines daily as: "B ritish go home, this is not your country, return our country to us." In all big towns and villages the cry from politicians for Independence was heard louder and louder, so that everyone in the country was imbued with the spirit of Independence. Resolutions were made to fight for it if necessary or if the B ritish were unwilling to return Burma peacefully. Just then the British were sending out hints as to their willingness to give Independence to Burma. On seeing this, the Karens said to themselves that if the Burmans are going to get Independences we too must be given a state and we must ask for it.

On the 30th June 1945 a meeting was convened under the Presidentship of Sir San C. Po at Ahlone Karen quarters in Rangoon. A resolution was passed at this meeting that a request should be made to the British Government to hand over the whole of Tenasserim Division to the Karens to be administered by them . At that moment the whole country east of Sittang was still under the occupation of Japanese troops. Therefore no representatives from Tenasserim Division who were directly concerned could come. As a result the resolution made at that Conference did not carry as much weight as it shoulds so it was decided to postpone the demand for a while.

In the beginning most of the Burmans thought that the British were only using diplomacy to keep them quiet, but day by day the genuine intention of the B ritish to grant Burma her Independence became more evident, and the talk of being independent in the near future was the main topic heard from everyone and everywhere in the country.

Realising the urgency of the case and the necessity for prompt actions four Karen leaders from the K.C.O. (Karen Central Organization) were elected to represent their case in England. They left Rangoon on 26th July in 1946 in the S SS . "Carthages" arriving in London on the 25th August. The Karen masses were somewhat dissatisfied with the four leaders for their failure to reveal full details of their plans.

The four leaders were:-

$\begin{array}{llll}\text { Mr. Sydney Loo-Nee, Bar-at-Law } \\ \text { Saw Po Chit } & " & " & " \\ \text { Saw Ba U Gyi } & " & " & "\end{array}$

On their return the leaders did not make known to their people what they had done in England and what had been accomplished. Therefore little was known about their mission to England. On the other hands a certain amount had been revealed in their pamphlets, which were published and distributed in England. The publications contained such facts as the origin of the Karens and that they were the first settlers of their present location in Lower Burma and part of Siam. They remained strictly loyal to the British throughout the war and rendered every possible assistance for the successful prosecution of the Japanese war. They also pointed out that it was the desire of the Karens to be given a state with a seaboard and to continue their existence within the Commonwealth.

The present is the time of Democracy, when each country is governed according to the wishes of the people, and is unlike times of old when one monarch ruled according to his own will. The rulers of today find out what are the wishes of the masses and accordingly frame and execute rules and regulations. The Karens began to take a little interest and came to know that all the time they had been ruled 
according to the majority's wishes, but owing to their neglect of politics they found themselves to be at least twenty years behind the Burmese. They now realise that without taking an active part in politics in such times of Democracy, they will never obtain their object and the wrong done to them will never be redressed, and it will be they who will suffer in the end. In fact, they have already started to feel various disadvantages through their personal experiences and are determined to go all out even though they are twenty years behind. They say that with determinations hard work and common sense there is no reason why they should not be able to catch up with the otherss If not, they are bound to sink and remain at the bottom for ever.

In connection with the Karen State, it will be of interest to know briefly about the Karen political organizations. They are as follows:

(1) Burma Karen National Association (B.K.N.A.)

Object: to unite the Karens and work for their advancement.

(2) Karen Central Organization (K.C.O.) and, later, Karen National Union (K.N.U.)

Object: to gain the Karen State and work for their advancements

(3) Karen Youth Organization (K.Y.O.)

Object: to work with the A.F.P.F.L., and try to obtain as much as possible for the Karens.

Both the K.N.U. and K.Y.O. were really working enthusiastically to realise their aspirations, and worked hard almost day and night. The K.N.U . believed that, without the Karen State where they could grow up in their own way, the Karens would soon be swallowed up by a stronger race and might even become extinct one day. With this object in view, they went all out to educate their people on the subject, which no doubt opened wider the eyes of the Karen massess

The K.Y.O., on the other hand, contended that there would be little left of Burma proper if a Karen State were to be sliced off her, and both would be so small as to serve no useful purpose either for the Karens or for the Burmese, as they could no longer command respect from any foreign country. Therefore they sided with the A.F.P.F.L. and have worked with them since.

As stated previously, Karens as a whole took littlesor no interest in political affairs. Therefore it was not very easy for the Karen leaders to make their followers understand their aims and objects and arouse their enthusiasm. It was hard enough for the Karen masses to digest the policies and objects of one political party, and therefore they were completely at a loss when confronted with the conflicting views of the K.N.U. and K.Y.O. who were pumping hard into their ears different ideologies. Owing to these two contrasting views of the K.N.U . and K.Y.O., some Karens began to wonder which party was really the leader of the Karens and really working for the benefit of the Karens. Some, true to their characteristics, refused to do anything with either party, saying both were untrustworthy. At the same time, in their hearts there was a deep yearning for a genuine leader to follow. Once convinced, they are faithful followers. As for the third party, the B.K.N.A., the oldest of the lot, seeing that the difference between the K.N.U. and K.Y.O. had already caused a good deal of headache to the Karen masses, they retired to the background, but gave their support to a plan of either party, if they considered it to be in the best interests of the Karen people.

In 1947, on the 3rd and 4th October, there was a conference of Karens under the chairmanship of the K.N.U. at Moulmein, Daingwunkwin quarters. It was a 
very important conference indeedn Representatives of all Karens from all over Burma were present. Two important resolutions were made theren

(1) That this Karen Conference does not accept the constitution of the Union of B urma Government hitherto made because the said constitution does not include the granting of a state to the Karens to satisfy their aspirationsn

(2) To request an independent sovereign Karen State of the following areas:

(a) Tenasserim Division including Toungoo District.

(b) Irrawaddy Division.

(c) Insein District

(d) Hanthawaddy District and

(e) Nyaunglebin sub-district.

When representatives got back to their respective places and when the two resolutions were made known to the Karen massesn they were much appreciated by them. It was the feeling of most Karens then, that the existence of a Karen State would soon materialise, while the leaders were convincing them, because they were united in their demand, in the same way as the Burmese who got the whole country back through their unity.

In other wordsn as the Burmans were looking forward to their "Shwe-mo-ngwemo" "milk and honeyn" so were the Karensn after gaining Independence and their State. Some Karens say the British were broad-minded because they returned Burma to the Burmans andn on the same analogy, the Karens were sure to get their State from the Burmans, and they thus had reason to thank both the British and Burmese in anticipation.

The Karen masses were very happy indeed for all they were looking forward to; but the leaders did not realise that to get a separate Karen State from the Burmese was not the easy matter it seemed.

It was decided by the K.N.U. leaders that a demonstration should be staged by all the Karens wherever they may ben to show the wishes and unity of the Karens in support of their two resolutions, which were considered not strong enough to press home their demands. So 11 th February 1948 was fixed, and instructions sent out to all concerned. In briefn it appeared that the demonstration was quite successfully organized and carried out at all big Karen centres. There were a few places which were out of the way and where instructions did not reach the people in time and so they failed to take part.

On the wholen the strength of the Karen masses in support of their demands for a State seemed to be pretty powerful.

In the same wayn as each and every Burman without exception gave his support to get Independencen so the Karens were to queue up behind their people for their State. It is not strange, but human naturen the more so with the Karens, for their menn women and children will come out en masse if it is for the sake of gaining a state whether or not they know the full significance of their purpose. The K.N.U. leaders like Saw Ba U Gyi, Thra Tha Hto, Mahn James Tun A ung and Saw Tha Din were much encouraged by the successful outcome of the demonstration and redoubled their efforts for the cause. They were also convinced that all the Karen masses were behind them.

At this juncture the K.Y.O. leaders were really put in a very awkward position for not supporting the demand for a state. It was not strange to hear such remarks made about them by the Karens that they were wonderful Karen Leaders 
who not only want a state for the Karens but are opposing it. Indeedn they were in a very awkward position.

On the strength of the two resolutions made at Moulmein conference and the demonstration, the K.N.U. leaders sent up a letter requesting a separate Karen State to the Government of the Union of Burma on the 3rd of February 1948 as follows :

To

The Prime Minister

Government of the Union of Burma

Dated 3rd February, 1948

Rangoon

At the meeting convened under the Chairmanship of the K.N.U. in the Karen School at Moulmein on the 3rd and 4th of October 1947 in which the Karen leadersn representatives and Karen masses were presentn the following two resolutions were made:

(1) That the constitution of the Union of Burma does not cater for an Independent Karen State;

(2) Therefore, to request from the Government of the Union of Burma an Independent Karen State to include the following areas $n$

(a) Tenasserim division including Toungoo district

(b) Irrawaddy division

(c) Hanthawaddy division

(d) Insein district

(e) Nyaunglebin sub-district

In accordance with the two resolutions the President and Secretary of the K.N.U. on behalf of the Karen nation are herewith forwarding an application to request for a Karen State. The granting of a Karen State being a deserving casen a reply in the affirmative would be expected within a month after sympathetic considerations have been made by your Government.

signedn

Saw Ba U Gyi

Presidentn K.N.U.

No. 5, U Loo Nee Street

Rangoon.
Saw Tha Hto

Secretaryn K.N.U.

As soon as the K.N.U. put up this application the interest of all political parties of Burma concentrated on the Karen State issue and they almost forgot all the other affairs already on their hands. The K.N.U. on the other hand, redoubled their efforts to press home their demands and exhorted their cause to the Karens almost day and night. Opposing them was the K.Y.O. who declared that it was unfair for the K.N.U. to claim all the areas mentioned aboven They saidn if the Karens must have a staten they should claim only Karenni Staten Salween district and adjacent areas to be known as "Kawthulay." To claim over and above that is unfair.

The Karenni State had always been independent and ruled by the Karens' own Sawbwas, and had not been under anybody, not even the British. It is very rich in minerals of various kinds but poor in agricultural products. Owing to its wealth in minerals it does not suffer any hardship as all its needs can be imported from outside.

But the Salween district is very wild, thickly wooded and hilly and also backward. It produces nothing in sufficient quantities for its people; even ricen salt 
andn in fact, all essential commodities have to be imported from outside. It is also not rich in minerals as is the Karenni State; a very poor district indeed, very unhealthy and malarious. It has an area of $2,852 \mathrm{sqr}$. miles, with about $83, \mathrm{n} 86$ inhabitants who are nearly all Karens, very few of other nationalities being found there owing to its unhealthy climate. Its population is estimated at only about 20 per sqr. mile. If it is to be compared with the monkey population, monkeys would be three times that of men. Hence, it would be appropriate to call it "monkey country .H The K.N.U. contended that this area had already been more or less exclusively inhabited by the Karensn who alone can live theren and there was therefore no need to specially ask for it to be converted into a Karen State. By accepting it the Karens would have to forego all their minority rights in Burma proper, where there are 60 Karens for every one in the K.Y.O.'s proposed state. Under the circumstances it would be much better to remain as they are rather than accept the K.Y.O.'s Kawthulay or State. The Karen States, as envisaged by the two parties i.e., K.N.U. and K.Y.O., were in absolute contrast because it is evident that the K.N.U. was asking for the best part of Burma while K.Y.O. was asking for the worst part of Burma.

In order to find out the wishes of K.Y.O. followers, representatives of K.Y.O. and Saw San Po Thinn who was then Karen Affairs Minister, met the Prime Minister $\mathrm{U} \mathrm{Nu}$ in Parliament from 1st to 4th March, 1948, where discussions took place.

On the 1st of March, 30 representatives of K.Y.O. from the Irrawaddy division met the Prime Minister to express their views. They said that they did not agree with the demands made by K.N.U. nor did they want a separate staten and that they wished to remain in the Union under the existing constitution.

On the second of Marchn 26 representatives from Tenasserim Divisionn including Saw Chit Sein, Saw Norton Bwa and U Hla Pen met the Prime Minister to give their views. They stated that, although they were in favour of having a Karen State, they did not agree with the demands made by K.N.U. and wished to have only that envisaged by the K.Y.O. to be known as "Kawthulay ."

On the 3rd of Marchn representatives from the Pegu division gave their views. Like Tenasserim they wished to have "Kawthulay" only, and to remain in the Union of Burma under the existing constitution. They also suggested changing "Kawthulay" into "Karen State.H

On the 4th of March, representatives of the K.Y.O. from all the three divisions and representatives of the Government met in Parliament. At that meeting it was decided that the Karens were unanimously agreed to ask for "Kawthulay" only as a Karen Staten It was also agreed that a Committee be formed to enquire and decide such matters as demarcation of boundaries and various others concerning "Kawthulay." The Committee was to consist of 4 Burmese from the Government side and 4 Karens from Karen Affairs Department, with the Secretary to be a Burman from Home Ministry. The four Karens were Saw Norton Bwan Saw Pha Hti, Saw Ba Yinn and Saw Donation. Of the four Karensn Saw Norton Bwa was to be Presidentn and the work was to be completed in four months.

At this particular time in all big towns and villagesn the prime topic was the Karen State. Nearly all papers, specially Burmese papersn carried big headlines with their own comments and interpretations, so much so that there were many who began to get anxious about communal clashes between the Karens and Burmese. Everyone who had the privilege of reading papers, read them very carefully so far as they concerned the Karen Staten Some Burmese newspapers carried in bold headings the views given by K.Y.O. representatives, emphasizing that the Karens from Irrawaddy and Tenasserim divisions wished to remain in the Union and were 
not in favour of having a State. This contradictory statement of the K.Y.O. representatives made many people wonder about the split among the Karens. In actual fact all the Karens were in favour of having a state.

Saw Ba Zan, M.Pn from Amherst Districtn whose statement was carried in bold headings, stated that the K.N.U. had made an unreasonable request for a Karen State. To justify such a demand the Karens must be the aborigines of such areas, or be in majority, but the Karens fulfilled neither condition. He also advocated action against K.N.U. leaders for causing tension, saying that some ignorant Karens who attended the K.N.U . meeting came back to Amherst District full of hatred and with the desire to have vengeance on the Burmesen He continued to say that a rupee for a rupee (now kyat) for both the Karens and Burmese is fair, but the K.N.U. demanded half a rupee more than the Burmese and therefore he could on no account agree to such an unreasonable demand.

It will be remembered that the K.N.U. put up an application for a state to the Burmese Government on the 3rd February 1948 with the expressed request for a reply within one month. Having received no reply by the 3rd of March, they decided to call for another meeting to include all representatives from all over Burma. The object of this meeting was to press home their demands more energetically for realising their aspirations. There were some five hundred representatives who attended this meeting. Saw Ba U Gyi was the President and Thra Tha Hto was secretary .

At the meeting Saw Ba U Gyi began by thanking all the Karen leaders and representatives for their whole-hearted support for the Karen State. He continued to say :

It is not our intention to disintegrate Burma as some people have reason to fear because we quite realise that anything which is detrimental to the Burmese will have the same effect on the Karens.

In fact, it is our intention to strengthen both the Karens and the Burmese by asking for a State. We asked for it once from the British, and once when Bogyoke Aung San was still alive, and once more now. This time the areas asked fornare more than before. We consider that the areas now asked for are a fair request, because historically they belong to us, whoever may say otherwise; it is our conviction that they belong to the Karens, hence our claim. What the K.N.U. asked for the K.Y.O. do not agree and they say that they are quite contented with Salween districtnor Papun arean They claim to be the Karen representatives but what Karens are they, if they do not try to meet the desire of the majority of Karens? It is now up to you all to find out what is the aspiration of the majority of the Karens and give your support to which you think best.

Regarding the Karen State, I, as the President of the K.N.U., had been asked by the Government of the Union of Burma to meet and discuss with Saw San Po Thin who is now the Karen Affairs Minister. He is all by himself and has no followers. I do not even want to see his face, for the single reason that after advocating boycott of the constitution of the Union of Burma, which he said was unfair for the Karens, and for which reason I resigned from the Cabinet, and after acting as President in that very meeting convened for this purpose he went and accepted the office which I vacated.

The Government erred in that, and instead of negotiating with the K.N.U. on this matter, they invited various people from the districts and dealt with them. Are these people Karen representatives? Not by any 
means. They have no followers whatsoever. It is now already one month and we received no replyn That means the Burmese Government is not going to give us a State.

The meeting concluded by unanimously agreeing to press home their demands more energeticallyn

When the Prime Minister invited the K.N.U. leaders, no doubt he did it with a view to discussing the Karen State. Most of the representatives were against accepting the invitation. They thought it was only another act of diplomacy to win them over. But Saw Ba U Gyi told them that if they use diplomacy, we too must use diplomacy, but this time we won't talk about requesting our State but about having it (to the great delight and applause of his audience).

He continued to tell them that he had already accepted the invitation and could not go back to his words; moreover, the question could only be settled by the Government in power; therefore, avoiding them would serve no usef ul purpose. Only by meeting and discussing with them could there be a result in one way or the other. Thus, it was decided that the following would attend: Saw Ba U Gyi; Saw Tha Hto; Mahn James Tun Aung; Saw Tha Din; Saw Bu; Saw Pale and two Phongyis: The party arrived punctually at 7:00 p.m. as invited. Saw Ba U Gyi, opening the discussion, asked the Prime Minister Thakin $\mathrm{Nu}$ about the attitude of the Government about the Karen State, to which the Prime Minister replied that it had already been laid down in the constitution in paras. 180 and 181 and the Government had no power to act beyond that. If the K.N.U. wished to have more than thatn it was up to them to get into the Parliament and change or amend the two paras. in accordance with paras. 207, 208, 209, 210 of the constitution. Although the Karens ask only "rupee for rupee" for the Karens and Burmese, it seems that the Karens are already getting half a rupee more. To which Saw Ba U Gyi replied: "Yes, I have heard that so many times before, but in actual fact the Karens have not yet received one anna."

After meeting and discussing with the K.Y.On representatives from Irrawaddy, Tenasserim and Pegu divisions, together with the Karen Affairs Minister Saw San Po Thin, the Prime Minister Thakin $\mathrm{Nu}$ gave out the following statementsn

He said the K.N.U. had requested Irrawaddy, Tenasserim divisions; Insein, Hanthawaddy districts and Nyaunglebin sub-district for the Karen State. It had come to the notice of the Government of the Union of Burma that it was the intention of the K.N.U. to run a parallel Government when they became strong enough by rousing the Karens with propaganda and demonstrations etc. It had also been learnt from the district of ficials that the Karens not only refused to surrender their unauthorised arms but were secretly trying to increase them by illegal purchase. This had been confirmed by the two Karen Ministers, Saw San Po Thin and Mahn Win Maungn on their return from a tour of the districts. The demand by the K.N.U. was not only unfair but an impossibility and was only the wishes of raw and uneducated people which would only result in splitting the Burmese and the Karens. To use armed force was easier said than donen It was alright for the leaders to incite their followers to do so but it only meant death and destruction to villagers in the districts. Supposing the Karens had taken up arms, do you think the Burmese would take it lying down? and give their necks like sheep? Certainly not. If they could not return two bits for one they would at leastreturn one.

Following the Prime Minister's statements some Burmese papers carried big headlines, some not without exaggerations which caused more anxiety and alarm to the general public concerning communal clashesn 
The Government also issued the following statement in connection with the Karen State. Rebuilding the new Burma was only possible through the unity of all peoples of Burma, Mons, Burmese, Karens, Kachins, Chins, and others that gained Independence for the country. Only with such unflagging unity could rehabilitation and progress be hoped for. But there are some among the Karens who are not quite up-to-date in world affairs and therefore have requested a Karen State. In accordance with world agreed policy the people who claim such areas must be the aborigines of that area and also in the majority. If we look into the matter it will be found that the areas claimed by the K.N.U. belonged to all, Burmese, Mons and Karens\$ not to one particular races Secondly, the Karens do not form a majority in these areas. In the Tenasserim division the population of the Karens is only $33.5 \%$ and in the Irrawaddy only $19.2 \%$ of the total population. Likewise in Inseins Hanthawaddy districts and Nyaunglebin sub-district the Karens are a minority race. The K.N.U. leaders therefore must be able to prove that the areas claimed were legally theirs and also that they are in the majority in those areas. If they are unable to do so and still insist doggedly on their claims it must be said that their claim is unjust and unfair in the present time of Democracy .

The Mons and the Karens who claimed the areas mentioned above must be able to prove before the world that it was their ancestors who first occupied and developed these areas and thus inherited those areas from their forefathers. If they cannot do so it must be said that they have no claim on those areas. On the other hands if they can prove that the areas claimed belonged to their forefatherss the Government should accede to their request in accordance with the democratic policies of today. If the Government refuseds it would be the Government who erred.

In the census there were only $1 \frac{1}{2}$ million Karens; as for the Mons, they were less than $\frac{1}{2}$ million. Both the Mons and Karens were dissatisfied with the above census and contended that there was a great deal of error in it. The present country which was known as Lower Burma throughout the British reigns was earlier known as Hanthawaddy Kingdom and was very prosperous. The inhabitants then were only Mons and Karens and Talaings. The Burmese conquered and ruled this country for 95 years and called it Talaing country. This was from 1757 to 1852 A.D. Both the Mons and Karens claimed to be the earliest settlers of Lower Burma. The Mons having been more easily absorbed and amalgamated with the dominant race, the $B$ urmese, a good number of its population had been lost to the Mon race. The Karens had also lost some of their population in the same way. Both the Mons and the Karens contended that, in spite of this integrations if the census were accurately takens their population could not have been less than one million for the Mons and $3 \frac{1}{2}$ million for the Karens. In 1942 after the Burmese-Karen communal clashes, it was said that the Japanese took a census of the Karens under their own supervisions and it was believed that the Japanese recorded 4 million. One other reason why the Karens believed that their number was more than what was recorded in the 1931 census was that, apart from big towns and villages, the Karens are more numerously found in all suburban areas in both Irrawaddy and Tenasserim divisions.

The population of the Karens as shown by the census of 1931 in the following areas is as follows:

(a) Pegu district 37292

(b) Hanthawaddy district 29754

(c) Tharrawaddy district 26712

To prove their argument, the Karen leaders conducted a census on their own within Nyaunglebin sub-district which is only a quarter of Pegu district, and there were already over 40,000 Karens. In Hanthawaddy district the number was over 70,000 and Tharrawaddy district over 60,000. 
From the above there is a good reason to believe that there must be a good number of Karens who had either not been counted in the census or else not been counted among the Karen population. Therefore if the census had been accurately taken throughout the country the Karens believed that their number would on no account be less than $3 \frac{1}{2}$ million.

The reason for this discrepancy is generally believed to be the fault of the recorders whose main concern would be to complete the register as quickly as possible. To sort out Burmese from Karens, Burmese Christians from Burmese Buddhists and Karen Buddhists from Karen Christians etc. may have been too tedious, and therefore it is not an impossibility that sometimes the whole village may have been put under one column. This is specially true with some of the Karens who not only became Buddhists but had also forgotten their language and lost their characteristics.

The question now arises as to who is the majority and who is the minority race in the Irrawaddy, Tenasserim and Pegu divisions. Owing to the question of the Karen State, it is most important to have a dependable and accurate census. The present one (of 1931) is unreliable and under dispute. Even according to that census the total population of Irrawaddy, Tenasserim and Pegu divisions was 6.75 millions. If Indians and Chinese, having a total population of 1.21 million, are taken off the grand total, the remainder would be Burmese, Karens and Mons only, whose population would then be $6.75-1.21=5.54$ million .

As contended by the Mon and Karen leaders, even if the population of Mons was still half a million and Karens, as proved by them, $3 \frac{1}{2}$ millions the two together would then be 4 million. Therefore in these three divisions the population of Burmese would be only $(5.54-4)=1.54$ or just over $1 \frac{1}{2}$ million. Therefore the population of the Mons and Karens is more than double that of the Burmese. It is therefore reasonable to assume that the Mons and Karens have the right to these areas. It is the sincere belief of the Mons and Karens that their population is more than what was recorded by 1931 census. The writer of the Karen State or the pamphlet above, said that it is not his intention to use the calculations shown above to suit his own purposes, but because the Mons and Karens do not accept the 1931 census as correct and, secondly, he himself believes the reasons given by them. This question of population cannot now be settled one way or the other. It is most important therefore that a comprehensive and accurate census be taken, and then only should a decisive decision be taken.

The three divisions claimed by the K.N.U. can roughly be described as Lower $B$ urma throughout the 95 years under B ritish rule, and as Talaing country throughout the 95 years under the Burmese rule. Before it was conquered by the Burmese it was known as Hanthawaddy Kingdom and said to be very prosperous. The Talaings, Mons and Karens were the first inhabitants to occupy and develop this country. For ready reference see the diagram below.

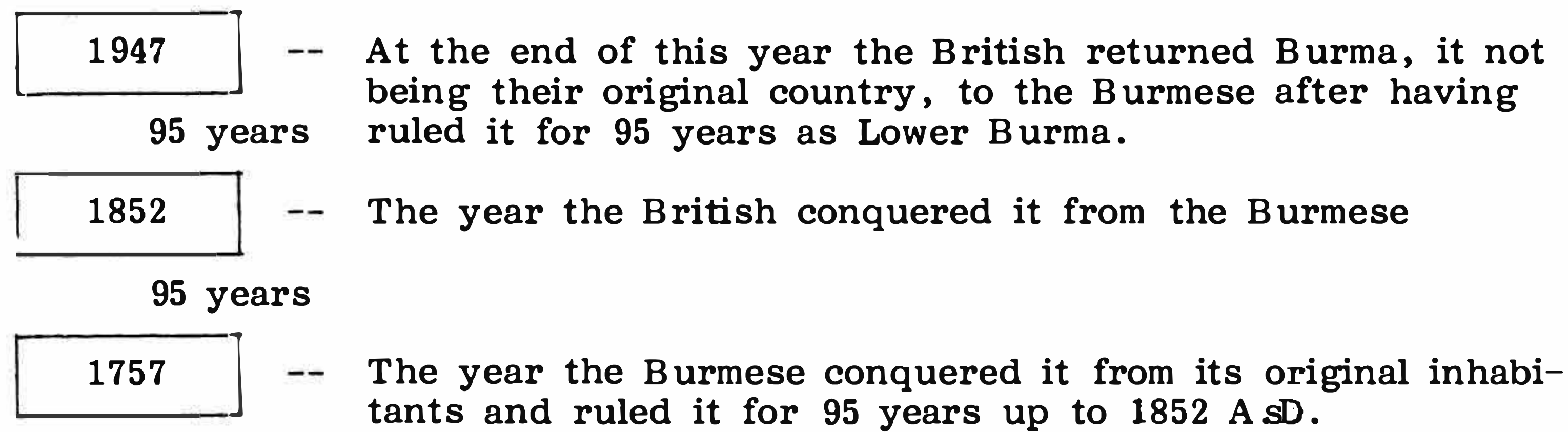


From the beginning it had been ruled by its own kings and developed by its own people or inhabitants, when and how long there is no means of telling, nor has it been recorded by any known historians

The country which has been claimed by the K.N.U. leaders, although conquered and ruled by the British for 95 years, was returned by them to the Burmese from whom they had conquered it, as it was not their original homeland. In the same way, although the Burmese had conquered and ruled this area for 95 years, it cannot become their country of origin. Therefore it is only just and fair if it be returned to its original people who first occupied and developed it. No one will deny that the reason given above is fair and just in the present era when theswhole world condemns and abhors any form of colonialism.

It is now most important to know who are really the aborigines or earliest settlers of these areas. Before the year 1757, and before this country or area was conquered by the Burmese king, the inhabitants were only Mons, Karens and Talaingss In Burmese history it was recorded as Talaing country. If we go to Thaton and Moulmein to find out more about the Talaings, we will find something very mysterious about these peoples The Karens do not like to be called as Talaings, likewise the Mons do not like to be known as Talaings. Mons, who are more numerous in Thaton and Moulmain areas, resent it very much if they are called Talaings and would retort that if you are a friend please call them Mons. It is indeed very mysterious and gives cause for wondering why the Mons and Karens resent being known as Talaings who were recorded by the Burmese in their history as having once ruled the famous and prosperous Hanthawaddy Kingdoms If we enquire from the Mons and Karens, especially the elders, they will reply that Talaings were Talaings from the very beginnings And if we say are not Mons and Talaings the same? They will at once say "No,s that Talaings are different peoples

Whatever the case may be there is no doubt that Mons, Karens and Talaings were the first people who occupied and developed this part of Burmas The question now arises as to who has more right to have this area now in dispute, the people mentioned above or the Burmese?

The answer therefore is: if the British had ruled it for 95 years and yet it had not become their country, can it become the Burmese country if they had also conquered and ruled it for 95 years?

\section{Notes by the Author}

Readers may wonder why the Mons are brought into the Karen State issue. To the best of the author's knowledge, it was the intention of the Karen leaders in agreement with the Mon leaders to make it a Mon-Karen State once it had materialised. Why they do not claim it in that name is not knowns But it is a fact that Mon rebels did fight alongside the Karens in the beginning.

The Karens wanted a State for two main reasons. (1) They wish to grow up in their own way and run their own affairs where they do not directly affect the Union of Burma as a wholes For instance, in schools and colleges they want to have the Karen language taught in order to not only revive but to vitalise their customs, culture, national characteristics and, above all, their religion. (2) They are suspicious of the Burmese and of not getting a square deal from them once they are in power. This suspicion is not without reasons. Before the British rule the Burmese were the oppressors and Karens were the oppressed. The author being a Karen himself, to avoid being accused of being biased in his statement, wishes to quote the well-known writer "The Burma Surgeon" in his book "My Hospital in the Hills." He said : 
The Karen-Burmese conflicts are age-old. In some ways they are similar in origin to those of the racial issue in the United States. The Burmese vastly outnumber the Karens of Burma Proper. Burmese had conquered Karens repeatedly, centuries ago, and the Karens had been in more or less of a state of servitude to the Burmese until the British had forcibly freed them in the First and Second Burmese Warss The Burmese had resented this forcible improvement in the status of the Karens. . . . A further improvement in the status of the Karens was the result of their acceptance of Christianity at the hands of American Baptist Missionaries; this, too, did nothing to improve Karen-Burmese relations. But worst of all was the fact that the British used the Karens to police the country. That the British also used Indian, Punjabi, Gurkhas Kachin, and Chin troops did not alter this resentment. Nor did the fact that Karens never reached the highest devel in government, though their capabilities fully warranted the top level.

The Japanese occupation did not help matters. During the occupation, restraints were removed and several massacres of Karens by Burmese in the Irrawaddi delta were reported. Like American lynchings, these reports weres far more sensational than were any reports of good Karen-Burmese relations. . .

Under General Aung San during the year 1946 the Burmese had handled the Shans Kachin, and Chin nationalists with a great deal of statemanship-more statemanship than the colonial B ritish showed. General Aung San realized that Burma would hardly be Burmas and would certainly not be a safe Burma without Frontier States.

Ultimately all this politicking took care of the proposed B ritish Frontier A reas except for the Salween District. The Salween District is one of the poor areas of Burma. It will need a lot of enlightened scientific development before it becomes self-supporting. It is the only area in Burma where the Karens are in a majority, but it contains the poorest and most backward Karens of all. It could not exist alone as an autonomous or as a B ritishdominated state, and therefore, when the British pulled out of Burma, it remained a district in Burma.

A great deal of trouble would have been spared Burma, and the Communist rebellions would have been wiped out, with the help of the Karens, long before they were, if the British had joined at a round table with General Aung San and his party and with the great Karen leaders--for there are not a few great Karens--and had sat there until a state had been outlined geographically which would have satisfied the Karens' nationalist aspirations and still have been acceptable to the Burmans. . . .

The trouble was that the Karens demanded just too much. They were seeking Tennasserim's tin and rubber, Moulmein's port, Toungoo's access to wolfram and Irrawaddi's rice. And they were demanding too much from a race which had dominated them from time immemorial until the B ritish had taken up the cudgels in their behalf and then left them on a limb. [Gordon S. Seagrave, My Hospital in the Hills (New York: Norton, 1955), pp. 117119.]

Divide and rule and stooges: The following is the author's own personal point of view. In this respect the Karens are not free from blame. They were not united in their statements given before the enquiry commission that came to Burma. It was a fact that the Karens were in favour of having a state and queued up behind the K.N.U. leaders, whose representatives gave evidence before the commission 
to that effect. Another partyn more astute and sophisticated with the dirty games of politics, gave evidence absolutely to the opposite. The policy of divide and rule and of using stooges was again in action even thenn by the very people who howled and detested these few words but practised them in a very fine art. Burma is no exception and the Karens are not above providing stooges. Being politically backward plus the availability of stooges among them they were politically outwitted and manoeuvred at every turn without any difficulty.

Probably most people who are friends of Burma and especially those who are in power today would like to see a melting pot or the amalgamation of all races in Burma to end all communal troublesn especially between the Karens and Burmese.

The author certainly does not entertain this view becausen if Burmese are still fighting among themselves just because of their differences in ideology although they are identical in all other aspectsn the solution between the Karens and Burmese is certainly not in the amalgamation or integration of races.

In support of the aboven the author wishes to quote Rev. Harris' observation recorded by him some years ago. He said: "Probably most missionaries to the Karens have supposed that they were losing their language and their distinguishing characteristics. It was feared that they were rapidly becoming $B$ urmanized; many of them speak Burmese as their own language and there are some who use nothing else, having quite forgotten their mother tongue. This tendency seemed so strong that many have expected the Karen language to disappear entirely in the course of few generationsn if not in a few decades. But on consulting the last Government census, [this was years previous to 1931] report of Burma, the writer [Revn N. Harris] was greatly surprised to learn that these fears were groundless. The figures given in the census proved that so far from being a decadent race the Karens are showing signs of marked virility. Not so very long since they stood fourth among the races of Burma in numerical importancen not only the Burmese but also the Talaings and Shans taking precedence over them. Nown on the other hand, they stand secondn the Talaings and Shans having been outdistanced. During the ten years covered by the censusn while the population of the Province (Burma) as a whole increased by about 15\%, among the Karens there was an increase of over $21 \%$. But of peculiar interest is the comment of the Superintendent of the censusn Mr. C. Morgan Webb. Referring to the Karens he saidn' In the midst of communities who have readily amalgamated with whatever tribe or race happened to be in the immediate vicinity, the Karens alone remain isolated and self-contained. The ready reception they have given to the teaching of Christianity has tended to strengthen their individuality as a racial group and to widen the difference between them and the remaining indigenes of the Province. While the Talaings at one time supreme over the whole deltaic portions of Burma are being absorbed by the Burmese; there is no suggestion that any such absorption or even that any amalgamation between the Burmese and Karen race is within the range of possibility." Here then is presented a phenomenon of a race which, a hundred years agon under the heel of oppression was probably no more than holding its ownn if indeed it was not in danger of actual extinctionn now steadily advancing in numbers until it has outdistanced all other races of Burman except the Burmese themselves. And this increase is ascribed by so impartial an observer as the Superintendent of the Census to the influence of Christianity. The case is even stronger than Mr. Webb put it. For in another place writing of the Sgaws and Pwos, the two leading Karen tribes, he saysn

There is a tendency for a Pwo dialect to give place to the Sgawn but the figures recorded do not enable the strength of this tendency to be 
measured. One might perhaps infer from this language that the Sgaw is supplanting the Pwo in the sense that those formerly speaking Pwo are now speaking Sgaw. But such is not the fact. Those who are familiar with the situation know full well that Pwos are not becoming Sgaws. They are rather being Burmanized and so lost to the Karen race altogether. The tendency to the Pwo to give place to the Sgaw must therefore mean an absolute increase on the part of the Sgaws, over and above the rate of increase of the Karens as a wholes This is the most significant because it is amongst the Sgaws that Christian Mission have been chiefly successful.

No fewer than sixty-five indigenous languages and dialects are named in the Government census and the list is by no means comprehensive or exhaustive. In olden times these races and tribes were comparatively stables but recently with a strong government over the whole country,improved communications and increased trade, nearly all of them are in a state of flux. The tendency is for the smaller tribes to be swallowed up in the larger. The census indicates that of the sixty-five languages and dialects listed no fewer than seventeen showed a decrease in numbers, three of these actually becoming extinct. Of the rest, fifteen have increased chiefly because they have only recently been brought into the area covered by the census operations and eight are so small as to be negligibles

The Karens alone although living along-side with the Burmese in the deltaic portions of the country, where it would seem that they ought certainly to become amalgamated with the latter race, are successfully resisting that tendency and maintaining their independent racial existence. A question very naturally to be asked, whether this persistant differentiation of a Karen race is desirable. Would it not be better for them to amalgamate with the Burmans and lose all their identity. It may be pointed out any race which has the virility to assert itself and maintain its integrity in the face of integration influences such as surround the Karens may be supposed in the very nature of the case to be a worthwhile race. The presentation is strongly in their favour at the outset. As to the Karens in particulars if something aside from brute force is of value in the worlds if virtue, idealism and integrity are real assets and not mere liabilities it would seem that the conservation of the Karen race with its language and customs is not a mistake but something to be desired.

For with its language, customs and comparatively high moral standard and everything else that makes it unique among the people of the East, it would undoubtedly not be a mistakes

The above record was made by a missionary to the Karens and an Official of the Government of Censuss round about the close of the 19 th century and it all pointed to support for the contention of the Karen leaders that Karens are more numerous than was recorded in 1931 census.

It was a fact that the Karens were the greatest minorities in Burma up to the time the British returned Burma to the Burmeses It is also a fact that they are not now in that position even numerically, leave alone in any other aspect. Once again it is the divide and rule and the availability of stooges among the Karens themselves that caused their undoing.

Karenni or Red-Karens and Taungthus now called themselves "Kayah" and "Paohs" respectively, in their own dialects, which still means "Karen" in the same way as the Sgaw called themselves "Pwa-ga-N gaw" and the "Pwo" "Plone." Of course, it remains to be seen in the next census if they will be recorded as one of the sub-tribes of the Karens or otherwise. 
As pointed out in the above paragraphs, one of the reasons for the Karens craving to have a state of their own is not only to grow up in their own way and maintain their identity but in the heart of their hearts they wish also to have advance studies of their language in their own schools and collegesn At least for their own people, to revive and vitalize their own customsn characteristics and religion etc. A question that will readily be asked not only by their pesent rulers but also by allnwho knew and are familiar with the Karens is if it is a worthwhile languagen The question will be answered by this author of the Four-Foot Colonel at the last paragraph of this chapter after quoting rall authors on the Karens to support his statementn

The Karens having lost their book of knowledge, as shown by their tradition, grew up illiterate so to speak, but the remarks that fell from the lips of their elders served as education for them in lifen They observed what the older people did and this was their educationn

The oral history of the Karens is well noted by the Karens, so much so that though centuries have passed, they know their traditions, so much so that Dr. Waden with the assistance of his Karen converts (so to say)n compiled the Karen Thesaurus, an epitome of knowledge and wisdom in four big volumes. Well did he title his compilation "Thesaurus," as it is indeed a Thesaurus of the Karen languagen Where did his (Mr. Wade's) converts get those materials from? They are those handed down from generations to generationsn The lapse of time reading back to ages past was still with themn Dr. Wade has said that to have it translated into English would be too great a task for him to cope with, that therefore the wisdom of the ages is now available in the Karen language. Mrs. J. H. Vinton, an enthusiastic Karen missionary, tried her hand to make a Karen-English dictionary with only the first letter of the alphabet and the first inflection which Dr. Wade adapted for the first alphabet in Burmese; it filled a volume; what would it be if all the remaining three volumes were to be completed? Knowledge, philosophy and wisdom is in them. In the Karen Thesaurus of four volumes are also to be found the folk-lore tales Drn Harris had compiled but they were in Karen. Now that there is a Karen written language adapted from the Burmese alphabets and there are printing presses, there is enough scope for Karen to be made a second language even in college grades. Once a Karen chairman is in the University the Karen language will become better knownn The Karen language is as much classical as Latin, Greek, Persian and Sanskritn If encouragement is given to the study of the Karen language there will be more than sufficient a curriculum from the Thesaurus alonen Further, there is Dr. Mason's translation of the Holy Bible both of the Old and New Testaments. There are also the books written by Dr. T. Than Bya (the very first man in Burma with M.A. degree and Doctor of Divinity [D.Dn]). They will be quite a sufficiencyn Language can not die and, added to that fact, publications in that language and materials in advancement of that language are to hand.

Studying customs, and thoughts of the Karens, Mrs. Armstrong, a missionary to Tamilians and Telegus in Burma, is of the opinion that the tradition is an unwritten Biblen Some people would say that the Karens are the lost tribe of Israel. This is not far from the truth for the sentiments contained in the Old Testament are the same as in the Karen tradition. There is a certain fact in the Book of Genesis in the Bible and, though the Karens may not have had a written language centuries ago, in their tradition they have the creations by God, and tempting of Eve by the serpentn Again, most of the books in the Holy Bible are written in diction and poetry forms which are part of the Karen language that, if it is a coincidence at all, it is indeed a strange coincidencen 
CHAPTER 13

THE KAREN SOLDIER

The following narrative was recorded by Mrs. Mason one of the poorer missionaries of the Karens, which was published in 1862 .

Therefore the incident must have taken place some years before that date. So far as it can be traced from the available records on hand it seems to be the very first time when Karens were ever enlisted in soldiering.

Mrs. Mason said:

Colonel Phayre, finding the independent Karens a pretty formidable host to deal with, resolved to form a mountain police of reliable Christian men who should be able to protect their own schools, chapels, and homes. Upon this I petitioned that fifty might be enlisted from the paddy cultivators on the plains; I thought it would help them to pay for their buffalos.

Among them would be found the fittest and strongest men now, for after a year spent in the neighbourhood of the schools [Toungoo], they could walk twice as far, carry twice as much, and accomplish more by contrivance than the rest. They would be the most obedient. It would inspire the men on the mountains, to see a body of soldiers practicing on their own parade ground. They would feel more secure, because the Institute Guard acts as the pulse of the nation, holding immediate and daily communication in a direct line with every village and hamlet, from Shwagyn to the Burmese territory on the north, and to the Red Karen Kingdom on the east. Then it was of importance to protect this post, as here would be grouped their most costly buildings, libraries, and school apparatus, and schools, too, in constant operation. But above all these considerations, the Kannee Pass led right through their paddy settlement, and this was the key to the city [Toungoo] from the north-east. Colonel Phayre was very willing to allow the arrangement, provided it did not too much weaken the guard on the hills. The new officer was empowered to organise the Karen police, but when he called for the men, they hesitated.

"Is Captain ------ going to organise us?" the Karen chiefs inquired in dismay. "Teachers we are afraid.s" They remembered the sacked villagers had obtained no redress; they remembered the rice land was not yet given, and when he sent for them only a few would come at all. Colonel Phayre's plan was to form two companies in the mountains, supply them with arms, and a certain quantity of ammunition monthly, and let them learn to use them themselves in the jungles, paying them a mere nominal sum, just enough to make the hill men recognise them as soldiers. This he and Mr. Mason had arranged, as the cheapest, wisest, and the best for the people, and it pleased the Karens far better to come to town at full pay.

Captain ----'s judgment was to make them barrack soldiers, and have them thoroughly drilled. Mr. Mason doubted the expediency of doing this, and did not like to meddle with it; besides, he had no time. Then Captain ---- turned to me:-- 
"Come" he said, "Mrs. Mason, they will do anything you tell them. Call them down and encourage them to enlist."

Mr. Mason, under the circumstances, thought I had better do it. So the Board of Managers was called. They immediately telegraphed to every pinnacle and glen by their runners, and in two days nearly two hundred chiefs and men stood before Captain ----, the Deputy.

"Great Chief, greeting," they said, as all appeared in highland garb and dignity; but they noticed he did not give his hand to them as Colonel Phayre and Captain D'Oyly had done.

"Tell them," said the Captain, "I will enroll two companies, with two captains, two lieutenants, eight sergeantss and one hundred and sixty men."

"Th'kyen," they replieds "we are afraids We are ignorant men. We do not understand white men's customs."

"Never mind; I'll send a man over here to teach you."

"Suppose your man drinks, he will spoil all our young men. Suppose he flogs, our people will all run away."

"He shall not do either. I know a good man who never drinks. I'll send for him."

"Would he be patient? We cannot learn quickly. We don't know Burmese talk."

"He shall neither flog nor drinks He shall be patient. I want you to remain on the plains until you have learned thoroughly."

"Th'kyen, we are chiefs. We have the care of our villages and of God's work on the mountainss We cannot remain constantly."

"But I will pay your captains forty rupees the month, the lieutenants twenty-five, the sergeants sixteen, and the sepoys eight."

"Th'kyen, let the great Governor keep his money. Give us arms, powder shot and land. We will learn to shoot; we will defend our villages and chapels."

"But I cannot give you these, unless you come and learn soldiers' business."

"How long must we stay away from our homes?"

"Till you have learned to be soldierss"

"Shall we then go back?"

"You shall."

"We cannot learn with the Burmans. They do not worship God. They drink and swear. Our young men would follow in their ways, and be ruineds We cannot drill with heathen."

"You need nots You may have Karen barracks in your own village, and be drilled here."

"How can we learn here, Th'kyen?"

"I will send men to teach you. You shall be entirely separate from the Burmese, and have nothing to do with them." 
"Shall we not have Burman officers?"

"No. I will make Karen officers.s

"Shall we certainly be taught in our own village, and not be called over to learn with the Burmese?"

"You shall."

"Th'kyen, our men cannot support their families on soldiers' pay. Give them less money and some land.s

"You shall have the land as I told you, every bit of it" (impatiently).

"Mama, we are afraid. If he means true, why does he not pity our starving brothers? Why does he not let us have the land now, and why does he not bring back the captives? Teacheresss we fear this Government man. Do you advise us to enlist?"

"I cannot advise. He appears truthful. You will get no arms unless you do enlist."

"Captain -..-, they are afraid,s" turning to him. "They fear Government will ensnare them. They will not enlist unless I give my word with you.s

"Pray give it, Mrs. Masons I will deal honourably with them.s" And so I gave my word that the promises made them shall be sacredly kept, and they gave in their names, the best chiefs being appointed officers.

It is the Sabbath--the chiefs and men are assembled for worship. Hark! What are they listening to? Why do the young men look at the chiefs, the chiefs at one another, and all at me so questioningly? Drive, drive, clack, clack! go the hammers--up--up go the rafters all through that holy day. Captain ----'s workmen building him a new house. Nothing is said.

It is Monday morning--the chiefs are on the verandah.

"Teacher, I want my name taken off from the list of Bos" (Officers). "And mine," "And mine,s" said one after another.

"Why, what's the matter now?"

"Oh, this ruler does not know the Ten Commandments!s As usual, I go to Mr. Mason.

"You had better return,s" he said, "and reason the matter. Tell them they will probably encounter many temptations, but on the other hand, if they do not enlists Government will give them no arms, and there will be no protection for them against their enemies."

I find them all assembled in the Institute.

"Then what shall we do?" They cried all at once, greatly excited.

"Don't you know what the Bible says?"

"Er er," answered Poquai. "'Let him that lacks wisdom ask of me.s" I leave them to prayer and consultation. Again the chiefs appear on the verandah.

"We have decided what to do,s" and they hold out a list of resolutions:--

"1st. We will not work on God's holy day."

"2nd. We will not drink arrack, or toddy, or brandy, or allow our men to use these drinks.s 
"3rd. We will take care only of our own country.s"

"4th. We will have permission to leave our business honourably, if we dislike it."

"Oh! Oh! Captain ---- won't sign any such paper,s I said, taking it to Mr. Mason.

"Then, we may not enlist," was the determined reply.

"Why do you name the third?" Mr. Mason asked just then stepping out of his study.

"Because, teacher, this Governor does not know the Ten Commandments. So whether he will be good or bad, we do not know. Supposing he is bad, then he gets angry with us ignorant Karens. He says, I'll punish 'em, so he may send us away over to the west and leave our homes unprotected; then an enemy may come immediately, destroy our villages, and break up our schools.s

"This is correct reasoning, but why the fourth resolution? That is contrary to all military usage."

"Teacher, we know our people. If a Karen does not like a thing, he'll run away. No officer, no money, no Government can keep him. Then we are made ashamed before the Great Governor, and our name is injured before our brethren in America." I begged them, if determined, yet to soften the matter down a little and be polite, which they tried to be, and then went up, asking for Captain ----'s signature and the Government stamp.

"Oh yes, yes; I'll sign it. Come with me to court." Immediately there comes a Burman goung, and pours down fifteen hundred rupees upon the floor before the Karen officers. Then another follows:--

"What's your name?"

"Chief Ledie."

"And yours?"

"Chief J'Que s" So he goes round and takes the names of all the officers in his book.

"Done! Take your money and be off!s gruffly, with a haughty toss of the head.

"Give us the paper, Th'kyen," entreat the chiefs.

"Go--go. I can't attend to you; I am full of business," says Captain ---in displeasure. to me.

"We wait, Th'kyen," and there they sat until noon, when two came over

"What shall we do, mama?" they asked in great distress.

"Have you signed any receipt?"

"No."

"Are you sure?"

"Yes."

"Have they notstaken your names?" 
"A Burman set down our names, but we have not touched the money."

"But you have given your names, and without the paper?"

"We gave nothing. The Burman took our names."

I referred the manner again to Mr. Mason, and he decided that they were under no obligation to take the money, without the signature promised to their resolutions, as they had told him they could not serve without it.

"We will not touch it!" they cried resolutely, and again took their seats to await his convenience. Two o'clock comes, three o'clock, and no indication of the signature; four o'clock, and Captain --.- leaves the court.

"We go Th'kyen," say the chiefs, rising.

"Take the rupees."

"Give us the paper, Th'kyen!"

"The Mengyee will give no paper. Take the money and be gone."

"We leave it here, Th'kyen."

"You dare not leave it. It is yours and you are responsible."

"We will not have it Th'kyen, without the paper."

A secret messenger is despatched to Captain ---. He re-appears, throws them a letter in Burmese, ordering them away gruffly. They desire to have the paper read, but are peremptorily ordered out that the doors may be closed. So they take up the money, and being half-famished, having sat there all day, they go immediately over to their Karen settlement, and send the assistant with the paper to Mr. Mason. Mr. Mason reads:--

"You are to obey me and the officers whom I place over you!"

"That all?" he asks in dismay.

"That is all."

Terrible indignation we knew would arise in every breast, that evening, among the Karens; and long we sat deliberating on what course to pursue; until Mr. Mason became alarmed.

"Go over," he says, "and try to soften their angers and help them to arrange for guarding the money through the night, for they surely will be robbed."

Ten o'clock rings--Shemoop is called--I jump into my little boat, and reach the landings The gong is rung, and in a few minutes nearly two hundred men in their Highland tunics, with dahs in hand, and in great excitement, are hovering close around me in the moonlight.

"Come, brothers, let us go in and talk over this matter. Now speak, each one. Say just what you choose," for I thought it safer to let them exhaust their pent-up feelings first. And they did speak, one after another, and poured forth their indignation upon the English Government, until every eye gleamed and many leaped to their feet, snatching their dahs and war-clubs in one wild clamour.

"Gently, gently, brothers."

"Sit down!" shout the captainss "Let Mama speak." Instantly every voice is hushed, every form has dropped upon the floor, and every eye is 
fixed to hear if I can say a word in extenuatione Very gently, in a low voice, I ask:--

"Are there not kidnappers in your nation?"

"Yes."

"Would you like Commissioner Phayre to declare you all kidnapperse"

"No--no--we understande"

"You saw the Great Commissioner at Klurlaee Did he ever tell you a falsehood?"

"The Great Commissioner tell a lie! No--no--he couldn't tell a lie! He knows the Ten Commandmentse"

"Then do not put this sin upon the English Governmente"

"No--no--we must not." ments?"

"Then againe did you not say this man knows not the Ten Command-

"Er--er. So we have reason to fear."

"Then, ought you to call all Englishmen bad?" ple."

"No--no, but why does he not learn? He knows bookse He is a disci-

"Is he a disciple? What does the Bible say is the beginning of wisdom?"

"The fear of God," answers Pwama, againe

"Without the beginning, can there be progress? Ought we not to pity rather than be angry with him?"

"Er, er, the teacheress is right; but we'll carry it back," exclaim the Captains, in one breathe

"May be he'll put you in gaol."

"Let him put us in gaol--let him cut off our heads--we can bear it," thundered the Captains, towering upe "Brothers," they cry, turning to the sepoyse "you have not taken one anna out of this moneye You are free. Go home if you choose. To-morrow we carry all back and pour it at the Governor's feete We won't eat Government moneye" In half an houre scores of these mene who had enlisted as soldiers at my earnest entreatye were tramping off up the mountains as hard as they could goe declaring they would never again come down at the call of Government. The next morning the Captains went up once more to Captain ---- with Nah Khan Qualaye and begged for the right papere

"I can never sign such a paper," he repliede "No Government officer would agree to such propositionse"

"If the paper does not please the Governor, let him not sign it; but let him dismiss his humble servants to their homese"

"I shall not dismiss youe You have enlistede"

"We go, Th'kyen," rising, bowing themselves oute

"Go where?" 
"For the money, my lord." And so he allowed them to depart; but on their reaching the rivern a messenger was despatched to call them back. They went and stood at the foot of the stepsn half expecting to see an execution.

"Hearn" says Captain --- "here's your papern" and gave them the veritable documentn just what they had askedn stamped with the Government seal. With joyful eyes they brought it to Mr. Masonn and desired us to write a note of thanks to Captain ----, which was donen assuring him that blessings would fall upon him from every pinnacle of the mountainsn when he sent us the following kind reply:--

"It gives me much pleasure to think that in carrying out the signing of the Karen petitionn I shouldn at the same timen have afforded you so much satisfactionn and I trustn with your available assistancen to be able to show that the Karens, if properly cared for, will prove as able settlers of the country as the tribes around them. I was much amused yesterday to see the Karens sit so utterly regardless of the rupees before them. I supposed they would grasp them like Burmese and Shansn but I see they are not to be bought over from the service of the great God whom you have so wonderfully introduced among them."

"Now, let us thank God," said Poquai, one of the Lieutenants, and in humble awe and love they bowed there at oncen and sent up their warm heart-breathings to the Almightyn whose own right arm had wrought their deliverance.

It was then thought that Captain ---- had only been trying these Christian of ficers to see what they really were; but, however it was, we knew the answer was from the Lord; and that night we took for our text in the Bible class, "I will sing of the mercies of the Lord for ever; with my mouth will I make known thy faithfulness to all generations."

One day a messenger came out of breath, sayingn the Bogyee Brigand, who had sacked the village mentionedn was pouring down his men towards the Christians againn The Deputy Commissioner sent up an embassy with a written messagen threatening this Rob Roy of the northn if he didn't behave himself, he would set a thousand rupees on his headn His ambassadors went as far towards the hostile region as they daredn to put up the message on a stake in the pathn and hastened back to court as hard as they could gon The pickets soon found the missiven and hastened to send it to their leadern In a few days a letter from the daring brigand was found much nearer homen bidding defiance to the Governmentn and telling the Deputy to bewaren or he would come and spear him and burn his town. The marauders came onn gathering strength at every step. Again he reached the plundered chief's villagen which now lay powerless before himn for his force was said to be several thousand strong.

"Seen" he saysn "what do you gain from these white Colahs? What have they done for you? Resist me now, and I'll burn your village; join me, and I will redress your wrongs in a different way." The plundered chief was entirely at his mercy; he had no power to resist the demands of such a sweeping forcen andn of coursen gave him food and shelter. Some said his people joined the warriors. If they did, it is not strange, though I think it was untrue; but the Border leader pushed onn coercing and persuadingn and under the magic name of Menlong, he carried all before himn 
The Deputy Commissioner is sleeping quietly in his own house--one nearest the invader's route. What dreams he of danger at that midnight hour? But hark! a knocking at the door. What is it?

"Th'kyen! Th'kyen! Menlong! Menlong!s"

Captain -- -- starts up--the English forces are called in haste to the battle--meet the brigand, who flies into the forest--Captain ---- with six Englishmen give chase--the friendly Karens see the Commissioner's danger --rush to the conflict--the robber is overborne, but he sells his life dearly --three brave Karens lie slaughtered at his feet--the prisoner is taken down to the spot which he had reached nearest to town [Toungoo], and is there hung.

Toungoo is saved--but was it saved by foreigners? No, indeed! It was saved by the Karen police of native Christians, who gave the warning, and who so boldly risked their lives for their ruler. [Mrs. Mason, Civilizing Mountain Men, pp. 345-58s]

In spite of such an excellent beginning the Karens remained unnoticed and were regarded as timid and cowards by their B ritish rulers for many years to come. In the year $1886 \mathrm{Dr}$. Vinton in his letter said that no one believed that the Karens could fight :

On 7 th of November before the troops crossed the frontier the Karens came down from the village where St. Barbe's insurrection was even then starting. I was not at home, but they thought thesmatter was so urgent that they actually forced an entrance at the Government house and begged for arms from the Government or to be allowed to purchase. They were prepared to offer a battalion one thousand strong to accompany General Prendergast. Their offer and fear of insurrection were laughed to scorn. You can scarcely judge how Rangoon had lost its head at the time. The only fear they expressed was that there would not be resistance enough to justify annexation.

When I reached my post from my sick bed in Amherst, Mr. Bernard (British Officer) thought the Karens cowards to be easily frightened but said will let them buy their guns, just to allay their fears.

I don't believe Mr. Bernard ever would have allowed us to buy arms, had he believed one word of my report. He merely thought to quiet the fears of the Karen cowards even after the Karens had been in action several times. Government House would not believe the Karens could fight.

Before I got back from the Karenni frontier my Karens went to a Secretariat Official in the last days of December of the same year and offered a levy. The Secretariat Official was as much as astonished as if a rabbit had appeared to him in full uniform and demanded a Henry-Martini rifle and offered to fight. Their offer of course was politely delivered with scarcely a distinguished sneer.

The key to all this conception is plain. No one either B urma Government Officials nor any one had gauged the quick work we have been doing among the Karens. They won't talk to these servility-loving officials, no one visits their villages and sees for himself what education and Christianity have done. The timid Karens have become men but nobody knew it.

Had that Karen battalion that had been offered marched due North from Toungoo with a B ritish force every Burmese soldier could have been dis- 
armed and killed or captured. As it was the arms which Sladen failed to take away were used against us. The ammunition and rifles were sent down even to Rangoon for sale. I have seen and handled them myself.

In the first days of rebellion I was talking with Captain ---- (another $B$ ritish officer) and he laughed at me when I told him that I would like nothing better than to raise and command a Karen Corps. After spending months with sepoys, and these very levies, and seeing the Karens charge, firing one volley and throwing down their guns and going to close quarters with their huge cleavers or dahss $\mathrm{C}-$ - came and apologized saying he was wrong to sneer at men who could fight like that. No one had gauged the unifying of Christianity or guessed that these loose grains of sand (the dams) had been welded into a terrible weapon. Men will fight when they know they are solids and no traitors among them.

The Karen fought his way into notice without encouragement and through the sneer of the Government officials; till at the Viceroy's Durbar even Mr. Bernard had to admit that he had never been so much astonished as at the Karens fighting so well.

It may be of some interest to readers to read about some of the battles fought between the insurgents and these timid Karens as recorded by Dr. Vinton:

Two separate insurrections burst on us at once. The one at Shwaygyin was purely Shans. It was headed by Mayankyoung and Kyaukalat Phongyis. The Buddhist priests have headed everywhere and actually fought themselves, a thing unprecedented in history. They cut the locks in Shwegyin canals and attacked Shwegyin in force. After their defeat they took up a strong position in the hills and easily defeated Major Robinson's detachment. They were at first far too strong to be attacked by the Karens in their headquarters. The Karens therefore confined themselves to cutting off their foraging parties. They had of course few guns and the Government would give them nones and so they set dacoiting the rebelss and arming themselves with captured guns. At lasts the position of the rebels became untenable and they were forced by hunger and the cutting of their foragers to move on to Pyapon. Here they were met by the splendid Police of the Salween hill tracts and the whole Karen population of the district. The insurgents were soundly beaten everywhere. Quarters were neither given, received nor expected for the Karens were furious and fought like Malays running amuch. The rebels were evidently trying to cross into Mineloongyee. The Karen Forester represented to the Chiefs in Siam that the timber revenue must at once cease if the rebels got across and so the despairing Mayankyong Phongyi found the river Salween lined with fighting men wherever he tried to cross. Then he tried to cross northward into Karenni State but was cut up by the Karens on his flanks. Hunger forced foraging parties and foraging parties were invariably attacked. Several Phongyi heads were brought in and all of course claimed as that of the five thousand rupee Mayankyong phongyi. I got news however that he had been seen crossing the hills to Toungoo. I of course warned our missionaries there and advised that the Phongyi be captured alives for I knew that unless we have positive convincing proof the Government would never give the reward to the Karens.

The rebels burst like a torrent on our poor Christian villages. The fighting was hard everywhere. I can note but one case the village of Thayku was attacked on Sunday while the people were all assembled at the service in the chapel. The Karens had no arms but still the rebels dare not attack them in the chapel, but merely surrounded them while a few looted the village. 
The moment the insurgents left the whole village rushed out and picked up their arms they had hidden in the bushes while they went to church and pushed off in pursuit, picking up recruits from the neighbouring villages. They fell into an ambush and their pastor and several of their party were shot dead. Though outnumbered three to one the Karens rallied and infuriated by the death of their pastor they flew at the rebels and dispersed them with great slaughter. Finally the whole rebellion was surrounded in Kawmekho valley near the foot of the great range east of Toungoo. The Karens had few guns in their hands but mostly used spears, shields and bows. The next day was Sunday. After a lot of trouble I got fifty smooth bores from Mr. Bernard. These were sent up Monday and Monday night the guns were handed over to the Karens. In thirty six hours they were on the field and on Friday Mayankyong Phongyi was taken. The fighting was heavy and bloody on the sides of the insurgents. Hunger had made them desperate and so fought for their livess The Mayankyong Phongyi was captured by a woman who clutched him till the nearest picket could come. The fight there was specially noticeable because every Karen clan except the Pghos were in arms that day. The Pghos were not found on the Toungoo hills. Even the Brees our most physically insignificant tribe sent a detachment from three days march away though they live out of B ritish territory. The tribes that once constantly were fighting one anothers now stood side by side. From a loose aggregation of clans shall be welded into a nation yet.

It may sound quite queer and even astonishing to some of the readers of the action taken by those early Christian missionaries who fought tooth and nail more like generals. They fought to save their mission fields and properties and the lives of their flocks which they regarded as of their own and of their children. In support of their action the writer would like to quote a few incidents of atrocious actions committed by these rebels. Also from Rev. Vinton's narratives:

The dacoit atrocities are horrible. The unalterable Turk, with his Bulgarian atrocities would have no chance in a competition with a Burman dacoit. Dacoity is reported, you dash off at the double quick for a dozen miles, a Karen levy trotting along abreast or even ahead of the Police Officer and missionary on their ponies; you find that thousands of rupees have been taken, the women lashed to a platform and then violated by the dacoits in turns, and kerosene oil poured over their clothes and set on fire. The men bruised and slashed, have seen all this, and are wailing like women around the horrible blackened lumps of charred flesh that were once their wives. You are shown where babies have been beaten to literal jelly in these mortars before their mothers' eyes.

Having no records to refer to and all those who could be referred to already being dead and gone, the writer shall only mention briefly to the best of his knowledge the remaining period before World War I when Karens were enlisted in regular battalions. At about the close of the 19th century a battalion of Karens were enlisted in the Burma Military Police at Monywa. This was just taking shape when it got mixed up in a brawl at a Pwe (open air opera), in which case the Karen troops took the law into their own hands and beat up their adversaries. It was said a B ritish Officer, the Deputy Commissioner or their Commanding Officer, was also injured in this mix-up. They were charged for mutiny and many were tried and convicted. There was an old man from the writer's own village, who was convicted for life but released with a reduced term somehow. The old man died a few years ago. Had he started writing this book before the old man died, the writer could have put in many more details about this battalion from first hand 
knowledge. Because of this regrettable incident the battalion was more or less disbandeds and some deserted and went home. Only a small number remained or rather were retained to serve. From that period Karens were debarred from enlisting for many years. From good works done by the remaining nucleus, the Karens regained somewhat their good name and reputation and gradually were taken in again, mixed with Gurkhas and other Indians. They continued to make good and the first Karen Officer to reach the highest rank (Subadar Major) was Bo Aung Bwint who also became A.D.C. to the Government of Burma.

Later ons Karens were also enlisted in the Burma Sappers and Miners together with Burmans. In this unit one of the Karens by the name of Bo Khin Po had also reached the highest rank of that time i.e. a Subadar Major and Honorary Lieutenant.

\section{World War I}

Only in the year 1917 were Karens enlisted in regular infantry battalions. In fact, all indigenous races were tried out for the first time. The first battalion to be formed was under the designation of $85 \mathrm{th}$ from volunteers of the then existing Military Police as hard core. Later it became 70th Burma Rifles and three battalions were raised under this names These battalions were hurriedly raised at Meiktila, Mandalay and Maymyo centres ands owing to large numbers of desertions\$ they were sent to India to complete their training. From there they were sent to Egypt for garrison duties. Some Karens did take part in the Mesopotamia campaign while some served in France with the Labour Corps. During this war Karens were also enlisted in motor transport units.

After the war, on returning to Burmas their designation was changed again to 20 th Burma Rifles. On Burma being separated from India in 1937 a 4th battalion was formed and the composition then was $50 \%$ Karens, $25 \%$ each of Chins and Kachins. The rest were dropped from enlistment for not having the required discipline needed by the regular Army then.

The Karens had never been tried as regular trained soldiers in modern warfares although they had a long tradition of service under the B ritish going back to the early days of B ritish contact with Burmas When the East India Company acquired the Province of Arakan and Tenasserim in 1827 a new era dawned for the Karenss one in which their dreams of justice and peace were at least to find fulfilment. That they seemed to have realised this is suggested by the help which they gave to the British against the Kingdom of Ava in 1826. They served as guards and intelligence personnel and a certain Major Snodgrass who wrote an account of the First Burmese War commanded their service. In the Second Burmese War in 1852 Karens again helped the B ritish and are reported to have acted as guides and intelligence personnel to the force which took Shwe Dagon Pagoda. In the Third Burmese War in 1887 they offered the service of a battalion which was turned down with a sneer; they however had to spend all that period fighting the Burmese rebels who rose up behind the advancing B ritish Forces (primarily to save their own skins of course). The help rendered by the Karens in subduing the rebellion in the back areas occupied by the $B$ ritish was no doubt one of the factors for the British success in subduing Upper Burma. In 1921 Karen troops of 2/20th Burma Rifles, together with Chins and Kachins were used in the Malabar rebellions In 1930-32 they were again engaged in quelling a rebellion in Burma led by Saya San. In this rebellion a great number of Karen levies were also used. All these services rendered by the Karens did not enhance their value very much as soldiers. A British Major who had served with the Burma Rifles and a writer of no mean repute, actually noted that the Karens are by no means good soldiers. 
That is purely his personal opinion of course and conceived in peace time. If he had commanded them in actual war he might have had different things to say. Unfortunately, those who had actually commanded Karen Companies for a sufficient length of time to know them well, like Major Taylor, Seagrim Rivers and Colonel Wheeler, have not noted anything down in black and white which can be quoted. Major Seagrim, in his letter to one of the resistance Karen leaderss expressed his hopes that the Karen soldiers would be as well-known as the Gurkha soldiers after the Japanese war. Of Colonel Wheeler, the writer was told by several Karen Officers and men that he invariably addressed them as "son" whenever he talked to them in Englishs meaning most probably that he had the trust and confidence in his Karen boys, as his own sons.

It was only in the Second World War that the Karen soldiers had some sort of chance to fight as regular soldiers. Even thens they were nowhere near properly trained and equipped to stand up against the Japanese troopss because from four battalions the Burma Rifles expanded to fourteen. The 5 th and 6 th were raised soon after war was declared in Europe, each with one company of Burmans; a battalion of Burma Military Police and Civil Police Volunteers, composed of Gurkhas and Kumdanis and mixed Burmans and Karens, was formed into 7th Burma Rifles; an 8th battalion was formed from the Burma Frontier Force of half Sikhs and half Punjabis, Muslims; a 9th was a reinforcement battalion based at Mekitila; the tenth (10th) a training battalion at Maymyo; the $11 \mathrm{th}, 12 \mathrm{th}, 13 \mathrm{th}, 14 \mathrm{th}$ were all territorial battalions composed of nearly all the races of Burma which was hastily raised for service in Burma. The Burma Auxiliary Force, which originally recruited only domiciled Europeans and Eurasians, now also took English-speaking Karens and other indigenous races. The majority in this categorys of course, were Karens. A small navy under the name of B.R.N.V.R. [Burma Royal Navy Volunteer Reserve] was now being raised in which Karens were also enlisted. Some Karens were also in the Burma Air Force. There was nothing that the Karen soldier or serviceman can boast of in the first round of fighting in 1941-42. On the other hands if the famous battalions of both British and Indian armies with excellent war records had been overrun and disorganized by the Japanese Imperial Army, it is not strange that the Burma Rifles which were more or less partially trained met with the same fate. Therefore, this particular campaign should not be taken to judge the material qualities of the Burma Rifle troops and Karen soldiers in particular.

General Wingate's expedition in which the Karen soldiers had been suitably trained and equipped is considered to be a fair test for grading them.

Morrison recorded that only 2/20th Burma Rifles reached India more or less intact. He wrote:

The battalion numbered then between 400 and 500 men, mostly Karens. Most of the other battalions had already been disbanded east of the Chindwin. In all about 800 men of the Burma Rifles reached Imphal. The men were given the choice of staying with the B ritish forces or of returning to their homes, in which case they would be given full arrears of pay, ten days' rations, a rifle and fifty rounds.

Nearly all Karens remained and a few that chose to return went as far as Chin Hills and served with the Chin levies.

The 2nd Battalion, now the only remaining battalion, went to India, trained in the Punjab and was reformed by Colonel $\mathrm{O}^{\prime} \mathrm{Ca}$ llaghan into ten platoons . . designed for reconnaissance. Wingate became interested in them and they went to join his troops training at Saugor. They fought 
with the utmost distinction all through the first Wingate expeditions and at its conclusion Wingate said they were the finest body of troops he had ever had. Every man of course spoke Burmese, and was well acclimatised to the country and conditions. The new Commander, Lieutenant-Colonel L. G. Wheeler, posthumously awarded the D.S.O., was unfortunately killed by a sniper, but casualties were not heavy although some men had to be left behind sick and others were taken prisoner. A Burmese Officer, Major A ung Thin, was also awarded the D.S.O.s and altogether the battalion won 2 D.S.O.S, one M.B.E.s one Order of Burma, seven Military Crosses, twentyone Burma Gallantry Medals (equivalent to the Distinguished Conduct Medal, or the Indian Order of Merit)s and twenty-seven Mentions in Despatches.

More than 300 men came out and Burmese speaking reinforcements were then sought from all over India. The battalion had done so well that for the next Wingate expedition it was planned to form forty-eight reconnaissance platoons, each commanded by a Burmese-speaking Officer of the Burma Rifles, each composed of three British sections and one section of eleven Burmesespeaking Burma Riflemens All the various columns and parties in Second Wingate expedition had these platoons attached and they did invaluable work, scouting, ambushing, obtaining intelligence, arranging for boats, food, supplies, etc. The battalion collected sixteen more M.C.s and numerous other decorations. Once again casualties were not too heavy and the battalion gathered so many recruits inside Burma that it came out stronger numerically than it went in.

When Wingate's so-called Special Force was disbanded, the 2nd battalion was reformed, in March 1945 on an ordinary infantry basis, one third Karen; one third Kachin; one third Chin. Unfortunately it did not take part in the final campaign that drove the Japanese out of Burma, after it had played such a prominent part in all the earlier operations. At the time of Japan's surrender many of the men in the battalion had been away from their homes for five years. There were now eight Karen Officers, with King's commissions, three Chins and one Kachin.

Truly a proud record. [Ian Morrison, Grandfather Longlegs (London: Faber \& Fabers 1947), pp. 213-15.]

Although the bulk of this unit consist of Karens, the credit gained for the unit must be equally shared with their brethren Chins and Kachins. The writer had seen it in Brigadier Fergusson's notes elsewhere on the Burma Rifles in which he mentioned the Military qualities of all the three races i.e. Chins, Kachins, Karens. He said, "I have commanded all, the Karens, Chins, and Kachins and they were equally fine soldiers.s' Fergusson is one of the brilliant soldiers that walked the earth and his appraisal should be given some value.

of the Karens, he continued:

Best watermen of all, however, were the Karens of the Burma Rifles. These men form the bulk of their regiment. . . . They belong mostly to the Delta, between Rangoon and Bassein, although some live in Tenasserim (the long tail of Burma which drops southwards into Malaya), and others, more wild in appearance and habits, known as "Red Karens," from the Karenni Hills. In the platoon we had one man from Tenasserim, $\mathrm{Pa} \mathrm{Haw}$, a little wiry smiling chap who in private life had been an "oozy" or elephant driver, and who was now John Fraser's orderly.

Nobody who had served with the Karens could fail to like them. Thoroughly biddable, and mostly Christians (to a degree which would put to shame 
most people who profess and call themselves such), they make admirable soldiers, intelligent, willing, energetic, brave. Many of them had been educated by the American $B$ aptist Missions and rejoice in incongruous names. Ba Than was their subadar, a rather solemn, conscientious man whose brother Wilson was in one of the other columns. Aung Pe, the jemadars spoke little English, but, though younger, was as good a man. Po Po Tou was highly educated, and had been at Kitchener College, Nowgong, training for a King's Commission; but, on the outbreak of war had sped back to Burma to resume his place in the ranks. He was the best educated of the lot. Billy, the Havildar-Major [Sgt. Major] was a tiny, wizened man, always smiling and very devouts who never went to sleep without first singing softly to himself all three verses of "Jesus loves me, this I know.s He was a particular favourite among the B ritish troops.

Their prowess in the water has to be seen to be believed. I have seen Pa Haw swimming mules almost continuously across a river for three hourss taking only the shortest of occasional rests, sitting naked on a rock looking for all the world like Peter Pans and laughing at the clumsy efforts of his $B$ ritish comrades, before plunging in again, and half-riding, half-swimming the recalcitrant beasts as he would. It looked as though he were whispering directions in the animal's ear. They would build boats from bamboo and groundsheets in a few minutes. I once saw John get his complete platoon across a seventy-yard river in eighteen minutes from the word "go," with equipment and clothings including Bren guns and wireless sets bone dry, and four mules and a pony; using nothing but their dahs (long knives) and groundsheets in addition to what the Almighty had planted by the stream. Never did I ask to command better or more lovable soldiers than these. [Bernard Fergussons Beyond the Chindwin (London: Collins, 1945), pp. 30-31.]

The writer remembers seeing B rigadier Fergusson's notes elsewhere on the Burma Rifles (may be "Fauji Akhbar"), when he sent out some of his Karen soldiers on a certain mission and that when the men were out he was forced to vacate his bivouac owing to enemy action. When his men returneds they found the camp full of Japs. Those few boys advanced consciously within range and erupted their haversacks of grenades into the groups of Japanese and then ran for their lives. At the end of his notes he asked: "How many of us would take such a risk against such odds?"

The writer as a Karen wishes to record here his appreciations and gratefulness to $\mathrm{B}$ rigadier Fergusson for having recorded the works of his Karen troops in his book.

The writer feels that Morrison had left out one decoration that was won by the $2 / 20$ th Burma Rifles. That is a Macgregor Medal won by Sergeant Saw Sein U, a Karen N.C.O. who happened to be well-known to the author. This medal is awarded to those who have done outstanding long-distance reconnaissance. To the best of the writer's knowledge, General Wingate was the only other recipient of this medal in the Burma campaign.

\section{Karen Levies}

The story of the Karen soldier will not be complete without accounts of the Karen levies of the Japanese war who were more than a little responsible for the capture of Rangoon on schedule. Major Seagrim of the Burma Rifles started the Karen levies at the risk of his life and never lived to see the fruit of his labour. 
Colonel Peacock, one of the sector commanders of the Karen levies known as "Otter" says:

I have left to the last all mention of Major Seagrim who, although not directly concerned in this operation, was, at its inception, the focal point of all attempts to start a resistance movement in Karenni. This is not the place to tell his story; of how he "stayed put" in Burma and gave his life to save the Karens from persecutions on his behalf. But he was very definitely an inspiration to the Karens and to us all, and I like to think that his valorous spirit, and those of Major Nimmo and Captain McCrindle who were dropped to him and died in Karenni, were more than a little responsible for the loyalty and gallantry shown by these hillmen throughout the campaign. [Cited in Morrison, Crandfather Longlegs, p. 165.]

Morrison tells how while Seagrim was still alive and in contact with G.H.Q. India, he was asked as to how many guns he would be able to use for his Karen revolt, and he replied: "Two months, before main allied main offensive begins 8000 , arms should be dropped with British officers in the hills; when offensive begins 12,000 more arms should be dropped in Delta, Pegu Yoma, and these hills to army ex-soldierss They will be able to cut lines of communications check the Burmese, cause internal chaos, deny hills and attack the Japanese.s Morrison wrote :

When Seagrim died he must have felt, that he had achieved very little. . . . [He] would not have felt that . . . if he had lived to see the great Karen revolt which took place a year later. It was the biggest irregular operation that took place in all South-East Asia Command. It was named -. Operation Characters Although in a military sense it was a completely new operation, it owed much to Seagrim and was indeed the actual development of his work in the hills. . .

At the beginning of 1945 large B ritish forces broke into the central plain of Burmas They had several hundred tanks with them and the same overwhelming degree of air superiority which the Japanese had enjoyed three years before. They had the measure of the Japaneses who had already . . s lost Burma. But the question of time was all-important. The south-west monsoon which starts towards the end of May turns all unsurfaced roads, especially those in the hills, into seas of mud.s When he took Meiktila at the beginning of March, General Slim, the commander of 14 th Army, had to take a tremendous decision. Should he play for safety, consolidate his forces in north Burma, and take Rangoon at the beginning of the next dry weather? Or should he go flat out for Rangoon and try to take it before the monsoon begins in May? It was more than 300 miles to go and he had two months in which to do it. It would have to be fast going. If he made it, well and good. But if the Japanese should succeed in putting up an effective resistance in Lower Burma and 14th Army was caught down there by the monsoon, with that immensely long and vulnerable line of communication to India, it would indeed be in a pickle. It is not right to say that General Slim took a chance. He knew what that magnificent army of his could do; he had a shrewd idea of Japanese strength; he had fought over this same country in 1942s He decided to go for Rangoon. The target date was May 1. On that very day Gurkha paratroops landed at Elephant Point at the entrance to Rangoon rivers The following day Rangoon was entered by troops of the 15th Indian Corps who had come by sea from Ramree Island.

In this dash for Rangoon, there were two places on the north-south axis where the Japanese might be expected to make a stand. The first was Toun- 
goo, 166 miles north of Rangoon, junction of the road leading up into the Shan States via Mawchi, Loikaw and Taunggyi. The second was Pegu, road and rail junction for their main supply line running east to Siams Of these two points Toungoo was the more dangerous. There were three Japanese divisions in the Shan States. If they could bring even one division down the road to Toungoo in time to make a stand there, 14th Army might find itself in a very unpleasant position and might not be able to reach Rangoon on schedule. Therefore it became of urgent importance to try and delay the movement of Japanese reinforcements to Toungoo. British officers were already back in the Karen hills organising levies and this was given to them as their primary task. It was a curious reversal of historys In 1942 Karen troops and levies tried to stop the Japanese coming up the road from Toungoo into the Shan States, in 1945 down the road to Toungoo from the Shan States.

The officers in charge of special operations in Burma now had plenty of equipment to draw upon, their own flights of aircraft, thousands of modern firearmss Wireless operators were short, and there were never as many B ritish officers available as could be used, but, even so, a steady flow of $B$ ritish and Karen volunteers, the majority drawn from various irregular units which had fought in Burma, parachuted in to the Karen hills. A number of B ritish officers and N.C.O.s had fought with resistance movements in France, Italy, the Balkans. At one time the demand for British officers was so great that volunteers from the Mediterranean were put in to the Karen hills after only three days in India.

It was a far cry to the old Oriental Mission days and the captured Italian rifles and the dud ammunition which were all that could be spared for Seagrim.

The first British officer to parachute into the Karen hills in 1945 was a certain Major R. G. Turrall of the Intelligence Corps. He was over fifty, with an M.C. from the last war, a mining expert who had spent many years in Africa. He was a small, leans hard man with a hatchet face, who always wore a hat about three sizes too big for him crammed down over his ears. He had been with Wingate in Abyssinia and also in Burma, a man of great endurance and almost fanatical courage. He landed near Pyagawpu on February 20, about eleven months after Seagrim's surrender at Mewado. He found the Karens in a very dubious mood, and during the first three days at Pyagawpu he obtained only four recruits. Then, on the nights of February 23 and 24, Lieutenant-Colonel E. H. Peacock landed with two Dakotaloads of British, Burmese and Karen parachutists. The arrival of these men immediately swung local Karen opinion. The Karens saw that the British really meant business and they proceeded to volunteer in considerable numbers. During his first week in the hills Peacock armed 250 mobile and 350 static levies.

Peacock's parties were originally intended to land at a dropping zone further north, but when they had arrived over it they had seen many lights, suggesting a Japanese encampment, and they had dropped at Pyagawpu instead. Their appointed sphere of operations was up on the Mawchi road and they soon moved up there. Peacock was a man of about fifty, a former Game Warden in Burma, who at the start of the war was farming in Rhodesia. One of his early B ritish officer reinforcements was Bill Nimmo, who landed not far from where his brother had been ambushed and killed near Mawtudo.

About one month later another area was built up north of the Mawchi road, under the command of Lieutenant-Colonel J. C. Tullochs another man 
of fifty pluss who became something of a legendary figure in Burma. A small dapper man with a monocle and a carefully brushed up-turned moustache, he had done many remarkable things, including (so the legend went) eight years in Africa as a big-game hunter and a year in wartime Germany disguised as an Arab carpet-seller. Amongst the Karens who served under Tulloch were many Padaungs. The husbands of the giraffe-necked women, proved themselves to be first-rate fighterss

One of the Karens who dropped to Tulloch was an officer called Kan Choke who, in the original operation designed to establish contact with Seagrim, had been intended to take the part taken by Ba Gyaw. He was a regular soldier with twenty-eight years' service in the Burma Rifless a substantive Subadar-Major, holding the honorary rank of lieutenant. He had been awarded the Burma Gallantry Medal in the first Burma campaign and had accompanied Thompson, Nimmo and Ba Gyaw in their long trek out of Burma. Owing to trouble with his eyes he was not able to jump in to Seagrim in 1943 but he went on nine of those abortive missions to try to drop wireless equipment to Ba Gyaws and he was a tremendous inspiration to the Karen boys in India. One of the staff officers in India says of him: 'When Character was launched and Tulloch was due to go in, Kan Choke came to me and pleaded to be allowed to go too--in order to kill some Japs and avenge Nimmo's death, I naturally hesitated as he had not been too fit, was then over fifty, and had only one eye. He was so importunate, however, that I finally acquiesced. To say his face lit up is to put it mildly. He went in to Tulloch and did extremely well. He was a most lovable character, with the very highest sense of duty $s$

Peacock's second-in-command, Saw Butler, also did extremely well. Originally a schoolmaster in Toungoos he had served for two years with the Northern Kachin Levies and had won the M.C. He was one of the most experienced of the Karen officers.

Operation Character was finally divided into four areass Walrus, Otter, Hyena and Mongoose. Walrus, commanded by Tulloch, was the northernmost, its area lying north of the Mawchi road between Bawlake and Loikaw. Otter, commanded by Peacock, was responsible for both sides of the Mawchi road, from the foot-hills near Toungoo to Bawlake. Hyena, commanded first by Turrall and then by Lieutenant-Colonel H. W. Howell (formerly with the Kailan Mining Administration in China)s operated round Pyagawpu. Mongoose, the last area to be formed, operated in the Papun-Shwegyin-Bilin area. It was commanded by Lieutenant-Colonel R. A. Critchley, M.C., a regular soldier who had served in Abyssinia with Wingate.

The scale of Character may be gathered from the fact that more than eighty B ritish officers and thirty B ritish N.C.O.s (mostly wireless operators) went in by parachute and probably twice that number of Karens. By the time the war ended more than 12,000 Karens had been armed. The main function of the British officers and N.C.O.s was to train, plan, and lead the Karens into their first actions and show them how to do it. One of them wrote later: 'The Karens are not militarily aggressive and do not love war for its own sake. On the whole the villagers in my area were timid and given to panic when first taken into action. But once successful under competent officers, once shown how easy it was for well-armed parties to ambush the Japanese, their fighting spirit rose high. They produced their own leaders and displayed initiative and a spirit of attack. They took rapidly to explosives and used them a lot without accident to themselves.' 
Walrus and Otter saw most action in the early stages, for they were sitting astride the Mawchi road. On April 13 they were sent word by $14 \mathrm{th}$ Army that the Japanese were beginning to send their 15th Division down from the Shan States. 14th Army was then at Pyinmana, so the chances in the race for Toungoo looked fairly even. But the Japanese were delayed for at least seven days by the attacks which Tulloch's and Peacock's levies made against them, by ambushes, road-blocks and demolitions. B y the time the forward battalions of the 15th Division debouched from the hills into the plain, 14th Army had already taken Toungoo.

The Japanese position after the capture of Rangoon was that they had at least 20,000 men west of the Rangoon-Mandalay road and about 50,000 in the Shan States and north Karenni. Those in central Burma now tried to get east into Siamn those in the north tried to get south and then east, also into Siam. In either case they had to pass through the Karen country. From May onwards the levies were sitting on all the main Japanese escape routes from Burman and all four areas, Walrus, Ottern Hyena and Mongoose, were involved in heavy and continuous action.

One of the outstanding kills was on the Shwegyin river where the local levy commander at one time had thirty Bren-gun teams lining twenty miles of the east bank. The Japanese fleeing east had to cross this river and either seized native craft or made rafts of bamboo. They were inevitably swept downstream by the strong current and thus had to pass at least one of the Bren-gun posts. In one week the levies claimed 900 Japanese and this was, if anythingn an underestimaten

One of the biggest offensive actions by the Karens was an attack on the Kempeitai headquarters in Kyaukkyi on April 15, led by Turrall. The Karens captured the town, killed forty-one Japanese and rescued some Karens who were being held by the Kempeitai. Turrall was slightly wounded. The levies withdrew and left the town to be defended by a detachment of the Burma National Army, which had revolted against the Japanese and was now fighting on our side. On April 19 the Japanese re-entered the town, catching the young Burmans of the B.N.A. asleep and unprepared.

The capture of Kyaukkyi was one of the few occasions when the levies made a formal attack. For the most part they confined themselves to the setting of ambushes and the sniping of Japanese on the mountain tracks. The most effective type of ambush consisted of a length of cordtex up to 200 yards long with charges and grenades at ten-yard intervals. It would be set off by pulling a string when a large body of Japanese were passing. The track for 200 yards--and any Japanese on or near it--would be blown sky-high. At the side of the track, when setting ambushes, the levies would plant sharpened bamboo stakes on which the Japanese impaled themselves when they dashed into the undergrowth. . $\mathrm{n}$.

A Japanese document which came into our possession after the surrender gives an interesting sidelight on the effect which all this Karen guerrilla activity had on the Japanese. It is a report to his divisional commander by a Colonel Tsukadan commanding the 215th Infantry Regiment of the famous Japanese 33rd Division:

1. In view of the mancuvres of our rear units, the country between Mawchi and Papun was vital. We had to pass through this country, which had natural advantages for guerrilla activities.

2. Sabotage troops proved very effective against small parties, rear units, walking wounded and sick. 
3. The regiment took the utmost pains in disposing and protecting units, but sometimes it received guerrilla attacks which disordered the plan of marching and often halted all movement.

4. The guerrillas spread alarming reports which caused great uneasiness to our men, and their morale was badly depressed. The non-fighting troops in the rear felt terror with the sense of hopeless battle.

5. Round Kawkareik there were only military police and rear transport units. They were very uneasy to see sabotage troops falling down from the sky and guerrilla activities on the ground. Also there were great difficulties in purchasing and transporting supplies.

6. The sabotage troops had been so well trained over a considerable period of time and their activities were so skilful that we were unable to obtain successful results. Our lines of communication were cut, and, as their activities increased, we had to keep strong guards posted day and night which gave the men no time to rest.

Operation Character exceeded all expectations. Apart from the delay imposed on the 15th Japanese Division whichn it might be arguedn had a decisive bearing on the Burma campaignn the Karen levies that summer of 1945 killed at least 12, $\mathbf{0 0 0}$ Japanese and indirectly were responsible for the deaths of thousands more, through air attacks directed by levy officers. At the start of the operation the staff of ficers in India thought they would probably be able to raise 3,000 levies, possibly 5,000. But eventually they armed more than 12, 100 . The ratio of losses must have been one of the most uneven in the history of warfare. Ottern for examplen killed more than 3,000 Japanese for the loss of thirty-four levies killedn Hyena more than 5,000 for the loss of thirty-five men. About half a dozen British of ficers and men lost threir lives. [Morrisonn Crandfather Longlegs, pp. 156-65.]

\section{The Unknown Karen Soldiers}

In the early days of the writer's military service his battalion ( $2 / 20$ th Burma Rifles) was sent to serve in India (Lansdown). A friend of his had the opportunity of visiting the Officers' Mess of one of the Indian battalions where he saw many pictures of those who had won various decorations and their citations. He was particularly interested in those winning victoria crosses. He said at the end it was written that there must be inevitably a few men who might have done wonderful things deserving two V.C.'s but no one responsible had either seen or heard of their deeds.

The writer thinks that there were some Karen soldiers who should come under this category, though in a lesser degreen during this second world war. Rifleman Saw Maung Tun who gave his life for his officer certainly deserves something. He himself unwounded volunteered to stay behind to take care of a seriously wounded officer. He was betrayed by a Burman and was captured by the Japanese while on foraging. He was tortured by the Japanese in order to reveal the whereabouts of his officer but remained true to the end. In the officer's own words in his book which the author of this book had the good fortune to readn he said Saw Maung Tun died a martyr's death.

There was also a young Karen Sergeant in one of the Territorial Battalions who had a duel with some Japanese fighters and won. He was then guarding the airfield at Magwe. According to his description it seems to the writer to be when the Japanese completely knocked the allies out of the sky of Burma. After Japanese bombing which knocked out nearly all the aircraft in the field and A.A. emplacementsn the fighters came in to complete the job. He ran into one of the gun emplacements 
which he thought would afford him more protection than his slit-trenchn The fighter pilots probably saw him, for they came down to strafe him in that emplacement. He retaliated with his bren-gun and sent two blazing that crashed not far from the airfieldn His story was substantiated by many Karen boys whom the writer knew and also by a Karen of ficer of his own battalion who is also known to the writern Moreovern this young lad at the height of Burmese-Karen communal troubles, when even the multi-coloured Burmese insurgents joined hands with the Burmese Government to fight the Karens, rose as a hero, to save his and neighbouring villages from several combined attacks from superior forcesn His prowess with the brengun earned him the name of Bren so and so from his adversariesn At one time, he stood his ground against an armoured car alone and killed the driver with a burst of his bren-gun through the loophole and the rest of the crew on vacating their vehicle. There are other instances where he showed exceptional valour all to substantiate the story of his duel with the Japanese heroes.

At the end of the rains, in 1942 some Karen parachutists were dropped in the delta, and from that time onwards they were dropped at regular intervalsn It must be remembered that things looked still pretty grim at that time and yet there were no lack of volunteers from the Karen servicemenn

A young Karen Lieutenant, Saw Ba Ohn Tin who was dropped by parachute but was captured and executedn He was first of all tortured and then enticed with freedom, pay, position and all, in order to reveal the plan of his organization, but he remained true to death to his oathn The failure of this young Karen Officer's mission was due to a Burmese officer in the same organization, "no name no pack drill, nh who was dropped before him and who, instead of carrying out his duty, surrendered himself through his father, who wielded some influence with the then Burmese government, soon after he touched the ground, revealing everything he knew of his organization's plann The Japanese therefore knew exactly when and where this young Karen Lieutenant would be droppedn And all they needed to do was put him in the bag as soon as he touched the groundn

The writer wishes to quote just one more incident under this heading. That is the first battle of Mawchi road in 1942. After the Japanese capture of Toungoo a Karen Coy which fought its way out of Toungoo was assigned to the Northern Karen levies and took part in a spirited action on the Mawchi roadn A glance at the map shows the strategic importance of this road, which is one of the main roads into the Shan States by way of Mawchi, Loikaw and Taunggyin The Coy, 150 strong was under command of Captain Thompson and held a strong Japanese Vanguard for many hours at the 28 th milestone, inflicting heavy casualties on the enemyn Boyt, by dint of driving all night from Mawchi, arrived in time for the battle and both he and Thompson had narrow escapes, Boyt being blown up (but only slightly injured) by a mortar bomb, and Thompson having a dud bomb rolled down the hill between his legs. When it became clear that they were greatly outnumbered and could no longer hold the Japanese they withdrew up the road blowing up all the bridgesn This action, for which Thompson was awarded D.S.O. and Boyt the M.C., and the destruction of the bridges delayed the Japanese for several days, and gave the Chinese 6th Army time to prepare positions east and west of Mawchi where they fought stubbornlyn Although Thompson and Boyt estimated that they killed only thirty Japanese, Karen villagers later reported counting more than eighty gravesn When they occupied Mawchi, the Japanese made propaganda amongst the people by saying that at the 28th milestone they, a column of only 700 men, had vanquished and driven back the spearhead of the Chinese 6th Armyn Standing instructions at that time were that, when an area was overrun by the Japanese, of ficers were to make their way North and levies were to hide their arms, lie low and wait for the British returnn In the beginning of 1945 , when the Divi- 
sion which the writer was in was in the vicinity of Tamu, he saw an account of these very 150 men (Karens) in a S.E.A.C. paper which said that the leader was captured and beheaded by the Japanese. Since Thompson and Boyt were alive, that leader mentioned therein would be no other than a Karen Officer (Subadar or Jemadar) who usually was 2nd in command of that company. This officer certainly deserved some sort of recognition for his loyalty and devotion to his duty, but he went unnoticed. It will take a book to enumerate all these unknown Karen soldiers who deserve some kind of recognition for their services, but their deeds were neither heard nor seen by any soldier.

\section{Martial or Non-Martial Race}

F. M. Sir William Slim said, "Cowards are almost non-existent, all men have some degree of physical courage." The writer entirely agrees with this statement. Whilst he was at the Army school of education, in his early days of Service, he recollects trying to remember the various martial races of India, including Burma. Then he only came to know who were supposed to be good fighters and who were not. He never gave serious thought to this subject until many years later after having served with many races of India and Burmas

The 1st Punjab Regiment to which he was posted was composed of Rajputs, Sikhs and Punjabis, Muslims, all of whom were renowned soldiers with excellent records and reputations from the 1st World War and also from their own history. He was fortunate to have an opportunity to serve with all these three races and see some sort of active service on the North-West Frontier of India, for a year fighting the Pathans whose fighting qualities are well-known. He had been with them alls going up pickets, opposed or unopposed, and had equal confidence in them all. Because he had trained with them, played with them, slept in the same area in camps, and even ate with them sometimes. In fact, he knew most of them so well that he had no reason to doubt their abilities, loyalties and devotion to their duties.

For their part, he had no doubt they had equal confidence in him. He remembers one N.C.O. who got a bullet through his pugri (turban) just a fraction of an inch above his skull; he just laughed it off and did not worry in the least. Their morale was always high for the simple reason, the writer thinks, that they knew that they were better armed than the tribesmen, and they could hit and kill with the weapons they handled. They also knew that there was an efficient system of administration behind them which would never fail them with food, water and ammunition supply. Lastly, they knew also that they and their dependents would be looked after in case of casualties.

When he came back to Burma he served with Gurkhas, Kumaonis, sKarens and Burmans in the Burma Military Police. Being only semi-military, these troops spent nearly all their lives in garrison duties. Therefore, when he was earmarked to help break the Taukkyan road block he must admit that he had not the same confidence as he had with his 1st Punjab Regiment troops, although there was no question about the martial qualities of the Gurkhas and the Kumaoni troops. When he came back to Burma he had under him a conglomeration of all Burma races (AngloBurmans, Indians, Chins, Kachins, Chinese, Karens, Burmans, Tavoyanss Gurkhas, including Wa tribesmen). Having trained them himself and knowing them well, he had equal confidence in them all. Even though they were only intelligence troops, they took on Infantry duties on several occasions and were in action several times. Even the two followers, a Madrassi and a Chittagonian, did not show any panic while bullets were flying all around us. Therefore, it is the conviction of the writer that there is no martial or non-martial race in the world. It all 
depends on the following: (1) training, (2) equipment, (3) leadership, (4) efficient administration, etc.

They must be so trained that they will have complete confidence in the weapons they carry, i.e., they must be able to shoot accurately and rapidly as the occasion demands. They must be trained in the same type of country in which they will be called upon to fight. Of course, physical fitness is the crux of all things. They must be armed and equipped better than the enemy, in any case, not inferior. They must be led by the officer or N.C.O. who has their respect and confidence, i.e. a leader who can do everything he orders, in fact, must be able to do better, if the occasion demands. Efficient administration in peace and war. Under such circumstances any race or man will fight as well as any other.

When Burma gained her independence in 1948, the Karens were well placed in the defence services and in their own right, not through any political pressure or string.

There were only two regular King's Commissioned officers and those two were Karens with nearly twenty-five years service each. Karens, being an indigenous race of Burma, have equal rights and obligations in Burma.

Although not many Karens took active part in the gaining of independence from the British they resisted and fought the Japs from the start to the end, for which they suffered most. Had not the Japanese been defeated, Burma's Independence could never have been given by the British. The author became the $C$. in C. of the new Burma Army on Independence or rather, was left by the British as such, with the concurrence of the Burmese Government, of course; H. Kya Doe, the only other officer who in fact was commissioned even a year or so before him, was nominated to be his Deputy with the rank of a Brigadier. Saw Donny, who had the same length of service as the two above and with a Burma Gallantry Medal gained in the Wingate expedition, became Quarter-Master-General with the rank of a full Colonel.

There were eight Lieutenant-Colonels, three commanding each of the Karen battalions, one the second battalion of the Burma Rifles of Wingate fame, one the 4th Burma Regiment (Gurkhas), one Burma Signals, one training battalion, and one A.Q.M.G. [Assistant Quarter-Master General] of South Burma Sub-District. B rigadier Saw Chit Khin, M.C., one of the two Staff-College-qualified officers, who fought in both Wingate expeditions with excellent reports, became a light Infantry Brigade Commander at Meiktila, having risen to a Lieut/Col. and commanded $2 / 20$ th Burma Rifles after Independence. Nearly all battalion and Coy commanders or equivalent unit commanders had a Military Cross or B urma Gallantry Medal, in a few cases, both. Major Saw Butler, who was 2nd in command of one of the Karen battalions, won both D.S.O. and M.C. Subadar Major and Honorary Lieutenant Saw Kan Choke won the Order of Burma, Military Cross, Burma Gallantry Medal, and was twice mentioned in despatches. He was the most decorated officer of the Karens.

With the exception of one or two who were war-time officers, the rest mentioned above had services ranging from fifteen to twenty-five years. Hence the writer of this book claims it to be the Karen's own right to be in that position on Burma gaining Independence. Of the small Air Force that was in the making, Wing Commander Saw Shi Sho became Chief of Air Staff. He was the most senior among the three battle-tested Air Force of ficers from Burma. In the small navy descendant of B.R.N.V.R. there were also some Karen officers and men.

Alas! Karens in such positions must have been a point of sore eyes to the Burmese politicians, especially those who were not in uniform. Not very long after 
Independence the straw began to show which way the wind blows. The writer was quietly offered the post of Deputy Prime Minister and the task to inform him fell on a very good friend of his, but he was rather rude in his reply.

Brigadier Kya Doen the most experienced and suitable officer for his appointmentn was conveniently got rid of as a Special Commissioner of Pegu. Then came the Burmese-Karen clash. Leaders of both Burmese and Karens made it appear in their statements that the trouble between then was purely political and not communal. In actual fact lower down the scale and in outlying districts and villages it was communal, pure and simple, and complete villages of both Burmese and Karens were wiped out by the victor of each clash. By this time all armed Karen personnel, regulars or irregulars, were disarmed and concentrated in camps. Those who refused to be disarmed naturally deserted with their arms and pushed of $f$ to their villages or nearest Karen centres to protect their homes and families.

The writer resigned and went on self-imposed exile in the Kachin State, where there are few Karens and Burmese to cause any such clash. A few senior of ficers were given long leave on $2 / 3$ pay. Those who allowed themselves to be disarmed were also given $2 / 3$ pay.

Karens who were in outstanding positionsn especially in the Army, are now back in the most insignificant positions in the Burma Army. At the time of Independencen Karens had three Infantry battalions and were well represented in every branch of other services right down to mule companies. The total number must have been well nigh ten thousand men and officers. Now only a handful of them are kept, no doubt just to show the world that Karens are given equal chances in the Army. To give one instance, the writer knew of a Karen officer, for whom he was responsible in order to get him commissioned in India, who had become a captain in 1943-44 and was still a captain in 1957.

The most regrettable thing, it seems to the author of this book, is the disbandment of $2 / 20$ th Burma Rifles as soon as he resignedn It was the one and only battalion of the Burma Army, that had some sort of record and reputation of two world wars. Can it be that the present regime does not want a unit with a good reputation or is it because Burmese were not represented in that unit in those days? 


\section{CHAPTER 14}

\section{DUN THE SHIKARI}

Like most of the Karens, Dun is a keen hunter from his boyhood. His main weaponsn in those days, were cross bowsn blowpipesn a Karen catapult made of bamboo, very much like the long bow, but with twin strings, kept evenly apart with two small pieces of bamboo twigs about an inch in length and securely held by threads to each side of the strings. At the middle of the twin strings there is a small belt about an inch wide to hold pellets of baked earthen balls about the size of a marble. All these weapons were made for him by his father appropriate to his age, size and strength. Hunting with dogs was also a common practice at that time. Cross bows were either made of bamboo or a special wood called paraungan which is hard and pliable. For a grown-up man the cross piece would be from four to six feet long. It is strong enough to kill barking deer with ordinary bamboo arrows, but with iron headsn and also poisoned ones one can kill any animal such as sambhursn boarn tigers, etc. Dun's bow was only about three feet long and only strong enough for a youth of thirteen or fourteen years of age. He could use it quite proficiently up to a distance of twenty to thirty yards. A blow pipe is made from a piece of straight bamboo, six to nine feet longn clean-bored with red-hot iron to make all the joints flush with the natural hollow of the bamboo itself. The arrow is about 12" to 14" long with chicken feathers neatly tied round it from the back end towards its middle to about four inches. The force depends entirely on the power of the lungs of the users. A normal healthy person can force the arrow to fifty or more yards. It can kill small birds and animals like doves and squirrelsn etc. It has two types of arrows, one just plain bamboo made as previously mentioned and with the tip hardened with firen and the other with an iron headn with a string neatly wrapped around from the iron head upwards to the middle where the string is firmly tied. The action is much like a harpoon. This type of arrow is used mostly for fishes at the time they surface for air. Of all these primitive weapons the Karen catapult was his favourite, in fact, he still uses it sometimes these days for fun. The action is just like the ordinary catapult but it requires a good deal of practice to master its use. A beginner invariably hurts his thumb as the line of flight of the pellets are directly in line with the thumb which is gripping it. Therefore if one does not get the necessary twist to clear the thumbn one is likely to have a swollen one. If, on the other hand, the twist is too much, the accuracy is much reduced with less power behind it. Once mastered by constant practice, it becomes automatic and instinctive, so much so that one has no intention and feeling of twisting it, and one can shoot as smoothly and even faster than the long bow. It can only kill small birds like dovesn pigeons and squirrels and the like.

Hunting with dogs was one of his favourite pastimesn when on vacation from schools. In those days one of their dogs was a particularly good hunter. A very tenacious and sagacious dog. It could pick up the trail of a hare or wild cats and deer, which left some sort of scent along the trail, even after a day. One thing, of coursen wild animals abound in those areas and having plenty of cover did not wander very far and wide, so the one that was put up may or may not be the same one that made the trail. On this occasion the cross bow was his weapon. On getting the scent of the animal the dog would show some excitement, and if the animal 
is somewhere near itn it will help occasionally and as the animal is yelping it will be joined by the other dogs which are called in Burma (pan khways) or stop dogs.

Wild cats are easier prey that hares and deer because they do not run far and soon climb a tree, once chased by dogsn Once they got up the tree it is the end of the chasen as they will either fall to the bow and arrow or be killed by the dogs as they jump down. Deer are naturally harder to catch in this manner as they outdistance the dogs in no time in and out of the thick undergrowth. What was done in those days was that nets were laid on game tracks in the direction they were likely to break through and then both men and dogs tried to chase them into the nets. Although the writer has had many a thrilling hunt in this manner, he remembers only once that dogs ran down a deern It was in the hottest month of the year in Burma after the seasonal jungle firesn which left the whole country-side sparsely covered with tall grass and shrubsn A deer was put up by this same dogn which was joined by two other dogs and three boys including the writern

The boys encouraged the dogs at the top of their voicesn The chase lasted quite a considerable length of timen For unknown reasons the deer kept on running in circlesn within the surrounding covern Had it made a break through to a distant and bigger jungle it could never have been caughtn This one was a fullgrown male barking deer. Single-handed the dogs could never touch himn His forelegs or hoofs can be used as effectively as spears; moreover, he is endowed with a pair of magnificent tusks which are as sharp as a razor's edgen Unlike any other species of the deer family, barking deer have deadly tusks. When it is aliven the tusks are shaky and there is a saying in Burma that "a shaky tusk of a barking deer, rips open the thigh of a tiger." It is also believed that the wound spreads as the wind blows on it. The writer can not vouch for the truth of this saying, but he did see both men and dogs that had been hurt by these deer. The wounds were pretty serious in each casen In the above casen the deer stood up to the dogs several times and only ran on when the boys caught up with them. As the heat became intense and also as it was six to one, the deer was soon cornered. When the boys caught up with the dogs there was already a life and death struggle between the deer and the dogs. The deer was squealing and clashing left and right as the dogs were tugging from different directions with their vice-like grip on the deer. One of the boys ended the fight with a stroke of his dah on the neck of the deer, and thus ended the most thrilling chase and hunt for the writer, in particular at that timen

Before he joined the Army he never had a gun for himself. Sporting guns were scarce, costly and difficult to procuren Only those with influence and wealth could obtain a license to hold firearmsn The only firearm he had had was a B.S.A. air rifle No. 1 which needed no license thenn It was a very effective little gun in those days, for small feathered game. He spent many pleasant hours with it on vacation where it provided him with much fun and meat for the potn It was no doubt the experience he gained from using this little gun that made him able to handle the service rifle with considerable ease and accuracy. He managed to pass his recruit test as a first-class shotn and throughout his later years in the ranks he retained his marksman shot-ship and was a battalion shot for one year.

Contrary to this he was never a good shot with a revolver. The . 45 Webley \& Scott seemed to be too big for his small hands and he hardly managed to score qualifying pointsn He never forgets one of his Coy. Commander's remarks on one of the target practices with .45n when he turned round to him saying: "Smith, what's the good of hitting the enemy on his ears and toes?" because nearly all his shots were on the edges of the figure 2 target which was of a man's sizer 
His first shot with a .12 bore gun was an experience that has remained vivid in his memory unto this day. It was at Maymyo when Colonel Coleridge was commanding the 2/20th Burma Rifles. A very keen Shikari who used to go out almost every weekend on open-seasons on jungle fowls snipe, woodcockss etc. On one of these shooting expeditionss Captain Rivers took the writer out more or less as a spectators knowing of course that "Smith" could not have handled a shot-gun before. The Captainswas more keen on hiking rather than shooting. After several beatss no birds seemed to have come over him. So he handed the gun to the writer saying "Now, Smithy, try your luck." Excitedly, Smithy took the gun and waited for the beat to start. The Captain was sitting nearby giving him instructions on how much lead to send off. The beat was on, and in a few minutes, a big jungle fowl came flying through the trees, with all its beauty and glory as one might says and it passed somewhat diagonally thus giving him more field to fire. As soon as "Smithy" saw the bird, up went the butt to his shoulders to aim and follow as best as a novice could and, keeping all the instructions in mind, he fired. At the same time he heard the Captain shout "got him.s" As for "Smithy" he saw nothings except a few feathers floating in the air. Being his first experience with a 12-bore gun, the excitement caused him to blink and thus he failed to see the rooster fall. He was very pleased with his initial success and, needless to say, very much encouraged by it. He does not remember how many he bagged that day, but that rooster with all its beauty remained embedded in his mind even unto this day. Thereafter the Commanding Officer, Col. Coleridge, often took him out on his rounds, or else would give him some cartridges to go out shooting for him for jungle fowl or snipe that abounded near by the lines.

One day, about noons he was sent for by Captain Riverss On arrival the Captain just said: "Smithy go and get me four snipe for this evening. I am having someone for dinner $s^{\prime \prime}$ Just like that, as if they were domestic birds that could be caught at anytime. All Smithy could say was "I shall try, sir," quite realising the importance of the mission assigned to him, and the difficulties it entailed. One thing that came to his mind was that there were not many snipe left in that areas and those that were left, were very shy, having been shot at many times. Moreover, snipe are not easy to shoot even by experienced shots, and what chances had he as a novice to get four snipe? With such thoughts running riot in his mind, he picked up a gun and some cartridges from the Captain and off he went. He walked round that swampy area several times but could notsget any shots offs One or two snipe came up, but they jerked and turned so fast that they were out of range before he could aim at thems He must have walked that area over four or five times until he was certain there wasn't a snipe left in that area. It was then about four or five o'clock in the evening and the sun was getting quite close to the horizon and his heart had almost sunk to the bottom with disappointments when he thought of another place which he remembered seeing some time ago and which was not very far. It was only a narrow strip of marshy ground consisting of some six or seven buffalo-wallows. This was a case of absolute hope against hope because if there was anything to be gots this was the last place he could find it. However, with his gun in readiness for use, he advanced further. He was very much surprised because he never saw so many snipe get up at the same time. He let fly both with his left and right barrels. He just browned into the bevy of snipe but the second shot was somewhat of a sport. Dropping two by the first and one by the second he reloaded quickly just in case any snipe got up and was ready to be shot. This marshy ground could not have been bigger than a tennis court so it was most unlikely that other snipe might be left after those two shots. Once again, he went round methodically in the hope that he might cover all directions. Indeed, there was one lefts which perhaps was hurt after those two shots and only got up when it was nearly trod upon. It got up and was so close to the gun that 
Smithys in surprise clean-missed it with his first shot, but it fell to his second just as it was about to get out of range. As a young mans he never felt so happy as at that time for having fulfilled the trust and confidence placed in him. Picking up his four snipe he briskly walked to the Captain's bungalow. The Captain, too, was no doubt pleased with Smithy for getting the four snipe he wanted for the evening and was beaming with smiles as he thanked and congratulated him on the success of his mission. The best part of it all was that Smithy, only a rifleman then, got ten bucks as "bakshish," which was more than ample in those days for a good feed and pictures for the evening.

\section{Last Shoot with Colonel Coleridge}

The battalion was about to leave Maymyo for a new station in India. Captain Rivers again sent for Smithy and instructed him to lay on a shoot for the Colonel for the last time in Burma. It was the last day before the move. So he sent out a couple of men to arrange for beaters and he, the Colonel and his friend followed the next morning. Many jungle fowl were bagged and the Colonel, of course, shot most of thems being not only keen but a well experienced and seasoned shikari. Late in the evening they came to a swampy place called Baker's Parus looking for snipe. There weren't many snipe that day, and the one and only snipe that came up was near Smithy's sectors which he shot. When the snipe was given to the Colonel, he was not only pleased but said: "Well Smithy, I shall tell the Memsahib that her last snipe in Burma is from you $s^{\prime \prime}$ Then only did he realize that the Colonel was looking for snipe for his wife. No doubts it was the Colonel who had instilled in him the keenness for this particular sport by taking him out on shootss and giving him cartridges to learn how to shoot because he could not afford to use them in those days. Laters this hobby came in as a great help to him at the time of disappointment and under adverse conditions. During his self-imposed exile which lasted several yearss shooting was one of the two hobbies which kept him in trim both physically and mentally. His other hobby was, and still is, gardening or farmings When not out shooting he would work at the soils plantings digging or uprooting what was not wanted in the garden. He is more keen on feathered game than big game. Although he had shot hundreds of deer of various kinds common in India and Burmas yet he had never shot bigger animals than sambhur and boar. As a sportsmans the only time he ever met with danger was while shooting in Myitkyina with the Kachin Officers, his ex-subordinates then. At that time, he was expecting a barking deers jungle fowl or pheasants to come outs but as the beaters got nearer, the gun to his left barked and, as he turned towards that gun, he noticed that something had fallen in the thickets and there was no doubt that it was a big animal. Instinctively he changed his shots from feather to buck shotss A few minutes later he saw the same animal get up and disappear into the thickets. He did not know what it was but guessed it was a big boar. He sat behind a small bush and waited. As the beaters got nearer and began shouting and yelling louder owing to several gun-shots which had already been fireds the big boar which he dreaded popped its head out from not more than 15 yards away. A wounded boar is well-known for its ferocity and the damage it can inflict on its enemies. Dun could see clearly its two dangerous tusks. No doubt it got sight of him and its muzzle was uplifted and directed at him. Feeling that it was about to charge and having no alternatives he took a good and deliberate aim which needed little adjustment then, and fired, hoping to drop it there and then, but instead of which it charged like a rocket; luckily, Dun put in his second buck shot as it charged towards him. Most fortunatelys the second shot caught the boar squarely on its forehead. The impact completely turned it round with all its four legs kicking skywards as if it was dying. Quite relieved and pleaseds Dun reloaded with two more 
buck-shots and waited for something else to come out. A few minutes later, and to his surprise, the boar got up slowly and moved into the bush when Dun plugged it with two more buck-shotsn but it moved on all the same. Dun had to thank his stars it was not strong enough to charge towards himn otherwise he would have been an easy prey since he was not more than five yards away from it. The boar was finally retrieved after more buck-shots about a hundred yards away from where it had got up. The beast weighed about 80 viss or 300 lbs.

One of the most amusing incidents that took place while Dun was out shooting was at Kalaw, with one of the beaters and a very famous shikari of Kalaw. They were all Danus (a mixture of Burmese and Shans), and were all Buddhists who are not supposed to kill anything either accidentally or deliberately but have the liberty of eating anything that is killed by others. Among the beaters there was an old boy who claimed to be 67 years of age and who had been a shikari throughout his life. His looks justified his claim and also his knowledge of game. Except for his stamina in going up and down hill not even the teenagers of his kind could keep up with himn He knew exactly where the deer would lie and break cover. For the years that Dun was at Kalawn he did not see him once putting guns in the wrong place. He never missed a shoot with Dun. If it coincided with any other partyn he would give some sort of excuse and go with Dun's party, for the simple reason that he would get his share of meatn failing which he would get some pocket money for country liquor which he relishedn The custom withnthese peoplen in fact with all the hill people of Burma, is that the one who kills the animal gets a leg, head and the skin; the rest of the meat is cut up equally to be shared among the other members of the party. For instancen if the remaining number is tenn then the pieces are cut up and shared equally. Sometimes one does hire them with daily wages. The normal daily wages for each is usually two kyats but in exceptional cases three kyats. Dun preferred the sharing-basis because the beaters really try their utmost to get the animals toward the gunsn no matter how thick or difficult the jungle may ben knowing that their reward depends primarily on their efforts.

Like all heathensn be they Karensn Chinsn Kachinsn whatever nationality they may be, Danus are great believers in $\mathrm{N}$ ats which abound in Burma. Each person has a Nat to do him good or bad, so does a house, a villagen etc. It must not be provoked deliberately or ignorantlyn in which case it has to be appeased with a sacrifice. Where they believe there is a Nat they will build him a shrinen invariably near a big banyan tree. Any animal living in that vicinityn be it a tigern deer, pig or jungle fowl, all become his, and they also believe that such animals have supernatural powersh because of their owner.

On one of the shoots at Kalaw and just before the close season for deer for the yearn and when each jungle must have been beaten ten to fifteen times previouslyn most of the deer were either killed or driven to distant junglesn On this particular occasionn the party had beaten not less than ten likely places without seeing a single deer that day. Tired and fed-up the party was heading for home. On the way they passed a Nat Shrine with a sizeable jungle around it. One of the beaters swore that there was a Nat-gyi in itn having seen it himself on many occasions. Dun at once turned round to the old beater mentioned above to beat it out, $N$ at or no Nat. But the old blighter and his followers would not be moved and started telling him yarns about how such animals were invincible through the powers of the old Natn etcn Moreover, they were most afraid of displeasing the $\mathrm{Nat}$ which might cause them sickness, accidents and even death. Having no such scruples Dun held a council of war, and proposed that he would declare to the $\mathrm{N}$ at that he alone was responsible, and the beater had only to take part indirectly by taking the dog to the opposite side and start it off by chucking a stone, while they remain 
talking aloud there. This idea seemed to strike a chord with them, since they did not have to violate the domain of the old Nat, and no doubt the prospect of taking home some meat in the last resort played an important part in making their decision. Indeeds there was a barking deer or the Nat's deer. Things worked out much simpler, as the dog, on getting the scent of the deer which might have been lying pretty close to the track, went in on its own, even before the beaters thought of taking indirect action on the job assigned to them. Chased by the dog which knew nothing about the Nat and its powers the deer flew past Dun like lightning. Within that split second, he let fly both barrels one after the other. He heard the deer crash down through the brush and down the valley, and also saw the dog closely following it, but had no idea, whether his shots were "hits" or "misses $S$ " Now, of course, the reputations of the Nat and that of Dun were at stake. The Nat had already gained a reputation with these people, while Dun had only boasted that he didn't care a damn for the Nat. So it all depended on the barking deer. If it escaped, the old Nat enhanced his reputations but if Dun got the deer the old Nat would only lose a little face. Then Dun would become a bit of superman only. While the party was looking for signs as to whether it was a miss or a hit they heard the squealing of the deer as it was caught up by the dog. The old beater shot down the hill like a rocket and soon joined the dog in the kill. So did the rest of the party, but far behind the old shikari. The rear party just overheard the old boy saying "It is the General who kills you, not me," as he put in a few strokes with his dah in support of the dog. When the party was all together, Dun sarcastically asked the old boy if he still believed in the invincibility of the Nat. He replied "Oh yes. See! The Nat let you have this one because it has a torn ear $s^{\prime \prime}$ It is their belief that Nats do not like to keep any deer with torn ears and broken horns. Indeed, this deer had a torn ear, so both Dun and the Nat remained where they were. They also had other superstitions. One must not pick flowers or mushrooms, however enticing they were. Nor relieve himself in any way at the gun position, big or small. Because it will offend the old Nats Dun did abide by their superstitions mostly to please them because without them he won't get a damn thing to shoot. But on one occasion it was just too much for him and outside of his control. He was put in position by the old beater mentioned above. As soon as the old beater went downhill to join the rest of the beaterss Dun was relieving himself in a big way. Maybe too many chillies at the last dinner. 
CHAPTER 15

\section{GOD'S CARE AND GUIDING HANDS}

This sounds very religious, and those who have no such scruples may even wince at the mere mention of this subject. But the writer feels that he must record his genuine gratefulness for all the blessings and guidance which he was convinced came from no other source than the Almighty God.

The writer does not or can not claim to be even a perfect Christian, but he does try to adhere to the teaching of his religion to the best of his mortal being's ability. He was born as a Baptist Christian and brought up very religiously in that religion both at home and mission school. In his young days he remembers that his whole village used to observe Sundays almost as rigidly as the Jewish Sabbath. Nothing must be done on Sundays, except worship and worship. There used to be at least four services on Sundays and more often than not a special service at the invitation of a certain church member at his or her residence and sometimes from home to home in rotation. Children were taught to pray first thing in the morning, and last thing at night. Playing, plucking fruits or vegetables, fishing or any form of degrading the Lord's day was met with severe admonishing and sometimes even with punishment. Any form of undertaking, be it ploughing, harvesting etc $s$, people always seek the blessing of the Lord. In schools a short service and Bible Study always preceded other lessons. At the end of each year there would be an examination on the scripture with various prizes as encouragement, such as books on religions gold and silver medals etc. Temperance was also encouraged at the mission schools and names were registered from volunteers who would promise to refrain from smoking and eating betel leaves and, of course, drinking any form of alcohol. Some gave promise for a limited number of years and some for life. Those who gave promise for life were regarded not with a little respect. The writer was in the latter group, a promise which was sent overboard when he came to the age of twenty-seven. It wasn't certainly an act which he can be proud of to look back. The following experience which he had in his young days may be of some interest to some readerss and some, of course, will no doubt take it as a mere coincidence.

Even with such strict bringing up on the religion to which he was born "boys will be boys.s On one Sunday, in the absence of his father and other elders, he and his elder brother intended to be naughty and disregard the Lord's Day . Moved by the number of fishes caught the previous day (Saturday), they went out fishing soon after father had left the house. Having anchored their dugout (boat) with long poles, fore and aft, they began fishing with rod and line, with that small voice ringing in his ears that it wasn't right, wasn't right. But fishes were so numerous that they hardly had time to change the bait, a fact that no doubt drowned the still small voice that had been ringing in his ears. The two brothers were indeed enjoying themselves. All of a sudden his elder brother dived towards the shore and swam like mads Not knowing what it all was he did the same too soon after his brother touched water; being not far from land they landed in no time; when they were on the dry ground he asked his brother what it was all about, what had happened, and his brother rebuked him for not seeing the croco- 
dile which surfaced only a few feet from his line. He personally never saw it nor had there been any crocodiles in that river. The incident did make them feel that the punishment was for disregarding the Holy Day. There were other incidents experienced by the writer but he will relate only one more incident which occurred during the last war when he was old enough and had enough reasoning powers. On one Sunday, he was invited to a shoot ands after dithering, that Satan, the old serpent got the better of him and he agreed to go, reasoning within that, as those who invited him were just as good Christians if not better, why should he not do so. So he went with his conscience pricking him all the while. They were out for partridges and quails and there were no beaters so they walked the fields. He had not walked more than two fields when he came across a russell's viper sunning itself full length as big as his forearm, slap bang in what would be his next step. He saw it just in time to put his brakes on and save his life. He automatically fired at the sleeping viper but clean-missed it at a distance not more than two or three feet and with a bird shot at that.

Although he can not claim to be an excellent shot, he certainly felt that he should not miss such a stationary target at such close range. The hissing of the snake as it wriggled into the tall grass, plus that conscience that had been pricking him, gave him such a weird feeling that he turned back there and then. Those who may think that it was a mere coincidence may do so but to the $4 \mathrm{ft}$. Col. they were lessons to learn for him.

As previously stated he can not and does not claim to be perfect in the faith he believes, but one thing is he does try to adhere to the teachings and bringing up he received at home, school and from those who hold the same faith. The things that remained with him unto this day almost as a habit are to say his prayers first thing in the morning and last thing at nights In other words, to say "Good morning" and "Good night" to father above, and when time permits to have a quiet period with the Lord by reading part of the scripture picked from the Secret Place or Upper Room or Sign of the Times etc. If there is no such time and also no Bible with him to meditate on some of his favourite verses of the scripture he remembers by heart, especially the Psalms 23, 121 etc. and prays according to his needs. For the best part of the war, he carried part of the scripture (Psalm 23) in his left breast pocket with the feeling of more or less as a charm. As he came to know more of the Book, he realised how greatly he erred, even though with such ignorance and more or less a robot. "His mercy endureth for ever" is the writer's conviction when he counts the blessings one by one. Nevertheless there are good things found in thee in accordance. 2 Chronicle 19:3.

Firstly, he went right through the war without a scratch, even though death and sufferings lay all around him, while a few lay dead not far from him and yet he received only some earth, and a few stones falling on him, from bullets which landed only inches from his head. On the way back into Burma there was a Japanese air attack. Thinking that the planes were the Allies since the Japanese planes had not been seen for a hell of a long time, he took no action until it was too late and realised that they were Japanese. He dived into the trench closely followed by a bullet only a split of an inch from his head.

He has mentioned elsewhere how he had been saved during the Burmese-Karen troubles and also how he was moved to change his plan to go to Kalaw. Had he gone to Kalaw according to his plan then the story of the four-foot Colonel would never have been written, because he would have been dead and gone. Not a Karen was spared, including the aged, the deaf and the sick in bed from arrests I knew of a Karen who was seriously ill, from typhoids who was carried down from his sick bed on a stretcher and put in jail. I knew of an old school teacher who never 
recovered from the shock and ordeal of being in jail and finally died from that experience. Had the writer gone there, he would have met the same fate or else fought it out to the last which would have been the most likely result. So why he was moved to change his plan whilst in flight is quite clear to him now.

The Chartered plane that was sent by Thakin $\mathrm{Nu} \& \mathrm{Co} . \mathrm{S}$ thens to bring his family back to Rangoon from Myitkyina and the subsequent good deeds done to him by the Kachin Deputy Commissioner all proved to be the guiding hands of God in accordance with his promise: "All things work together for the good to those who love the Lord,"even though he was more or less a robot in this respect.

Looking back to the 1942 withdrawal, there were many instances which clearly stand out nows that they were nothing but led by the guiding hands of God. Such as evacuating his family to his hometown or village instead of northwards as most officers did. Had he done so, it is quite possible that the family would have met the same fate as those hundreds and thousands that died on the way to India; his experience with the British Gurkha commanders when the Burmese Thugyi (Headman) saved him from falling into the hands of the Japanese (at the time nearly all Burmans were on the side of the Japanese); also to come unscratched through enemy action or disease which claimed many lives of troops and enemies.

Finally to have served throughout the war under two Divisional Commanders who knew him well with mutual respect, could not be said to be mere coincidence. 
CHAPTER 16

CONCLUSION

The rough sketch of the story of "The Four-Foot Colonel" has been completed since the beginning of 1957 only a few months from the day he decided to put it down on paper. But with one thing or another it has not been put in proper order, and till December 1958 and now 1960, the old $4 \mathrm{ft}$ Colonel, for various reasons is still in manuscript form. Whether it is going to be born into a book in print remains to be seen. If it ever comes out in print thanks are due to all those whom I have quoted in this book. My big salam to all of them dead and gone and those still living.

My special thanks are due to two brothers, Dick Bone (a Britisher), a brother officer of the 2nd World War, who got nabbed in Burma by the Beauty of Beauties and is now firmly anchored on the shores of Burma, a prosperous dealer in books. It was he who put the idea into the $4 \mathrm{ft}$. Colonel's head. On their meeting in his bookstall, Dick said: "why don't you write a book sir?" "Do you think I can write one?" "Yes, Sir. Why not?" "No Dick, not a bloody chance for the book even to pay for itself with my style and English.s" "That will be looked after by the publishers, Sir, don't you worry over that. All you need is to provide the facts $s^{\prime \prime}$ So it was Dick Bone who put the idea into the $4 \mathrm{ft}$. Colonel's head. The other brother is Mahn Saw Bellay, a Karen brother of the $4 \mathrm{ft}$. Colonel who raised funds somehow to obtain several books on the Karens by various authors on Karens, most of which are out of print, and cost him not less than 150 Kyats a piece.

However, it is now 1960, the $4 \mathrm{ft}$. Colonel is back again in the profession of his forebears from where he started life. That is farming.

The only difference from his predecessors is that he farms with machines instead of buffaloes and bullocks. Although it is a definite come-down from the rank and position he had reached, he is quite satisfied and contented in his retired lifes He was only forty-one when he had to retire due to political changes both in India, Pakistan and Burma. He could no doubt have got an appropriate job or even jobs appropriate to his status if he was prepared to be a stooge like a few of his own Karens. In fact he did get a hint to that effect. Not having. such blood in his veins, he rather chose the open air life of his origin rather than the stooge with good pay and position. Here ends the story of a "Four-Foot Colonel,s" a soldier with rare success but a sad ending.

"THE END" 